\title{
LA PATA COJA DEL TURISMO EN EL PERÚ
}

\section{ONE NO LEG OF TOURISM IN PERU}

Carlos Gamero Esparza: Universidad Inca Garcilaso de la Vega (Perú). carlos.gamero@ozu.es

\section{CURRÍCULUM VITAE}

Reconocido Periodista peruano del Diario OJO de Lima. Licenciado con Diploma de Honor en la Universidad Inca Garcilaso de la Vega.

\section{RESUMEN}

Es uno de los destinos más bellos y apasionantes del mundo. Sin embargo, su récord turístico está muy por debajo del estándar de otros países. Se ha lanzado un Plan Estratégico para impulsar el Turismo en Perú, pero éste no ha gustado a los peruanos. La riqueza de los recursos naturales y culturales del Perú, aupada a su mágica aureola de misterio y leyendas doradas siempre ha llamado la atención de visitantes y viajeros. Pero la codicia y el afán de lucro de empresas y empresarios vinculados, directa o indirectamente, con el turismo, son ahora los nuevos expoliadores, no ya del oro sino del patrimonio turístico de este país. Pero esto lo que está haciendo es destrozar siglos de historia. No se valoran tampoco la parte humana y las necesidades del turista. Esplendor y miseria se unen por culpa de un turismo de ricos que está matando al turismo en un país de pobres. 


\title{
PALABRAS CLAVE
}

Perú - Destino turístico - Recursos naturales - Turista - Empresas

\begin{abstract}
It is one of the most beautiful and exciting world. However, his record is well below resort standard elsewhere. It has launched a Strategic Plan to boost tourism in Peru, but it has not liked by the Peruvians. The wealth of natural and cultural resources of Peru, aupada to its magical aura of mystery and legend gold has always attracted the attention of visitors and travelers. But greed and profiteering by businesses and entrepreneurs, directly or indirectly to tourism are now the new spoilers, not of gold but of heritage tourism in this country. But this is what you are doing is to destroy centuries of history. There is also value the human and the needs of tourists. Splendor and misery come together because of a rich tourism is killing tourism in a poor country.
\end{abstract}

\section{KEY WORDS}

Elections - Leadership - Charisma - March 11

\section{ÍNDICE}

\section{Introducción}

2. El PENTUR: Por fuera flores ¿Y por dentro... temblores?

3. Matando a la gallina de los huevos de oro...

3.1. Turismo sin rostro humano

3.2. El "síndrome" del sitio "exclusivo" 
3.3. Lo que no quiere el turista

3.4. El "otro" turismo

4. Machu Picchu a trancas y barrancas

4.1. ¡Oh, Machu Picchu!

4.2. ¿Turista o "pan con pescado"?

5. Una "aventura" en Cajamarca

5.1. Valga un "paseíto"

6. Por esta pata "cojea"

7. Quejolandia: la voz del turista es la voz de Dios...

7.1. Mensajes recibidos en el periodo 2001 - 2004

7.1.1. 2004

7.1.2. 2003

7.1.3. 2002

7.1.4. 2001

8. Un "turismo" (de) rico(s) que está matando al turismo en un país de pobres (y un artículo que lapida la incongruencia)

8.1. Cuzco: esplendor y miseria. Artículo de Wilfredo Ardito Vega

9. ¿Sabía Usted que...?

10. Conclusiones

11. Para saber más

12. Notas

13. Procedencia de las imágenes

14. Recortes de Prensa I

14.1. "Machu Chicha"

15. Recortes de Prensa II

15.1. Sucedió en Machu Picchu

15.1.1. Dos huaicos aislan a 1500 turistas

15.1.2. "Identifican a desaparecidos"

15.1.3. Cifras 
16. Recortes de prensa III

16. 1. Mafia opera en el aeropuerto

16.1.1. Mafia bajo la lupa

\section{TEXTO:}

\section{Introducción}

Es uno de los destinos más bellos y apasionantes del mundo. Sin embargo, su récord turístico está muy por debajo del estándar de otros países -incluyendo algunos del mal llamado "tercer mundo"-, que han logrado basar su progreso en la llamada industria sin chimeneas. Si bien es cierto que en los últimos años se ha logrado reactivar en algo y tardíamente el sector, con la construcción de nueva infraestructura hotelera y la llegada de casi un millón de visitantes en el año 2003, aún queda mucho camino por delante. El reciente anuncio del lanzamiento del "Plan Estratégico Turístico Nacional" PENTUR, si bien pretende paliar las carencias de esta industria, no ha entusiasmado a los peruanos, ya acostumbrados a los "saludos a la bandera" de los anuncios políticos grandilocuentes, toda vez que muchos intentos similares han quedado en nada. La incredulidad y la indiferencia de la opinión pública han sido matizadas incluso por la Prensa especializada, ello a pesar de anunciarse también la existencia de préstamos y créditos proporcionados por un organismo internacional para poder financiar tal proyecto. No es de extrañar, entonces, la actitud asumida por la mayoría de los ciudadanos de a pie: nadie se hace ilusiones, para no desengañarse en caso de que esto no se haga realidad.

Es evidente, tal como veremos a continuación, que los redactores del PENTUR no sólo han cometido imprecisiones en algunos puntos, también han omitido aspectos 
fundamentales del mismo: se "olvidaron" del turista como ser humano y de la responsabilidad social que debe asumir la actividad económica turística frente a la coyuntura que significa la pobreza que afecta a gran parte de la población peruana. Es más, muchos de los recursos turísticos que el gobierno y la inversión privada pretenden promocionar como destinos, están ubicados en áreas geográficas empobrecidas que no reciben la presencia ni el apoyo del Estado y que no han podido desarrollarse adecuadamente ni sacar provecho del potencial que atesora su provincia o región. Todavía falta que políticos y empresarios del ramo se "pongan las pilas" y se hagan una autocrítica sincera acerca de cómo consideran y tratan a los extranjeros que nos visitan, a sus mismísimos compatriotas que gustan de visitar lugares turísticos en su propio país, y, también, aceptar su responsabilidad social. Este trabajo es una apretada síntesis de reflexiones y experiencias vividas por el autor como comunicador social como un simple turista, que ha tenido que vivir y desvivir lo que muchos llaman "capitalismo salvaje del turismo receptivo y nada recíproco".

\section{El PENTUR: Por fuera flores ¿Y por dentro... temblores?}

(...) Sin embargo, no es claro que la oferta de servicios turísticos esté preparada para recibir un incremento tan elevado en la demanda. Como se verá más adelante, la oferta se ha venido desarrollando de manera desordenada, concentrada y en sectores muy específicos, basándose especialmente en inversiones realizadas por empresas extranjeras, con lo cual las filtraciones hacia fuera se deben haber incrementado.

Norberto E. García ${ }^{1}$

1 "El Turismo en el Perú: Perspectivas de crecimiento y generación de empleo."

http://www.oitandina.org.pe/publ/peru/doc102/texto.html 03/9/04 
"Recordemos que ya en 1999 obtuvimos, gracias a la cooperación japonesa, un plan para el turismo, y que como él, muchos otros han terminado sólo en eso, en propuestas en el papel. Esperemos que éste no sea otro "plancito" más."

David Ría ${ }^{2}$

Hace casi dos meses, en la ciudad de Lima, el gobierno peruano anunció, por enésima vez, el lanzamiento del futuro "Plan Estratégico Turístico Nacional"3. Este proyecto a gran escala, aunque acierta en algunos puntos, se tambalea en otros, cruciales. Ya en décadas pasadas se anunciaron otros intentos oficiales para levantar el alicaído sector turístico peruano. Como señala el estudioso Norberto E. García4, estos "planes previos" nunca tuvieron continuidad y fracasaron, atribuyéndose esto a la incapacidad, indolencia e inconstancia de nuestros políticos, y también por la falta de una fiscalización que ha permitido al sector privado desarrollar esta actividad con poca seriedad y casi nulo sentido de la responsabilidad social. Por más de medio siglo, entonces, la "industria sin chimeneas" en el Perú, ha navegado en medio del caos organizativo, la corrupción, la informalidad, la impunidad y la casi total carencia de ideas y objetivos claros.

Por este motivo, y los que vamos a explicar, el Perú nunca ha podido ser lo que debería ser: una potencia turística mundial. Aunque la propuesta del PENTUR, previsto para los próximos diez años (2005-2015), pretende corregir rumbos, contra él conspira no sólo la inseguridad jurídica, sino también un ambiente social y político nada ecuánime. Además, campean las protestas y los reclamos del pueblo a un gobierno indolente y frívolo, incapaz de solucionar los problemas de fondo, los

\footnotetext{
2 "¿Un Plancito más?" Enfoque de David Rivera. Diario El Comercio. Lima. Miércoles 25 de agosto de 2004 http:/ / www.comercio.com.pe/EdicionImpresa/Html/2004-08-24/ImpTemaDia0183139.html 03/9/04

3 "Gobiernos regionales participarán en el diseño de Plan Turístico Nacional". Diario El Comercio. Miércoles 25 de agosto de 2004 http://www.comercio.com.pe/EdicionImpresa/Html/2004-08-24/ImpTemaDia0183141.html 03/9/04

${ }^{4}$ Idem 2
} 
mismos que, para mala suerte, han involucrado muchas veces a inocentes turistas que se ven envueltos en medio de las turbulencias populares (ver * al final de este apartado). Por este y otros motivos, el PENTUR corre el riesgo de quedar en sólo buenas intenciones por la forma como ha sido planteado y por los temas que no ha tomado en cuenta. En un país de coyunturas irresueltas, no se puede esperar otra cosa a menos que exista la voluntad política de un cambio radical. Por lo tanto, este "plan" parece haber nacido cadáver, sobre todo en el aspecto humano y la responsabilidad social. De allí la incredulidad nacional. Hasta ahora no somos capaces de recibir millones de turistas como lo hacen otros países americanos como México o Chile. Ni el gobierno ni los empresarios son capaces de hacerlo bien y con criterio. Esto por culpa de una mala gerencia turística, más que de recursos e infraestructura; y si llegan seiscientos mil o un millón de visitantes, los reciben "a la mala" y los explotan según el libre albedrío de malos empresarios y peores políticos. Explotan a los turistas y también le "sacan la mugre" a los recursos turísticos, muchas veces a costa de su preservación e integridad -es decir, los exprimen hasta el último centavo, aportando poco o nada a cambio-. Y así quieren traer a 5 millones...

"Durante la década de los ochenta el desarrollo del turismo fue prácticamente nulo. En efecto, entre 1980 y 1990, el número de turistas extranjeros se redujo de 373 mil a 352 mil visitantes, lo cual, como se muestra más adelante, se explica principalmente por el clima de inestabilidad económica y de violencia terrorista que vivió el país en dicha década. A partir de 1990, se aplican en el país un conjunto de medidas orientadas a estabilizar el país y reformar el patrón de crecimiento de la economía..." escribe, no sin razón, el periodista Norberto E. García ${ }^{5}$. Por su parte el recelo de David Ría ${ }^{6}$, Editor de la sección Economía del diario limeño El Comercio, no hace sino reflejar el sentir de los ciudadanos ante el pomposo anuncio del gobierno

\footnotetext{
${ }^{5}$ Idem 2.

${ }^{6}$ Idem 3.
} 
peruano de "reflotar" la actividad turística cuando en realidad hace tiempo que naufragó.

Desde los años 30 del siglo pasado, con la construcción de los primeros "Hoteles de Turistas" de la desaparecida ENTURPERÚ, en las principales ciudades del país, y después con la farsa fujimorista de los 90s (ver: 10. Para saber más: "¿El año de los 600.000 turistas?"), la anhelada bonanza del turismo en el Perú sigue siendo un espejismo lejano al que muchos tratan de agarrar pero se les resbala de las manos como en el cuento del palo ensebado. Y tal como están las cosas, parece que muy a pesar de los buenos propósitos, le va a faltar mucho, pero mucho de imaginación a la inversión privada para poder auparse a la altura de los países turísticamente más desarrollados, por lo mencionado capítulos abajo.

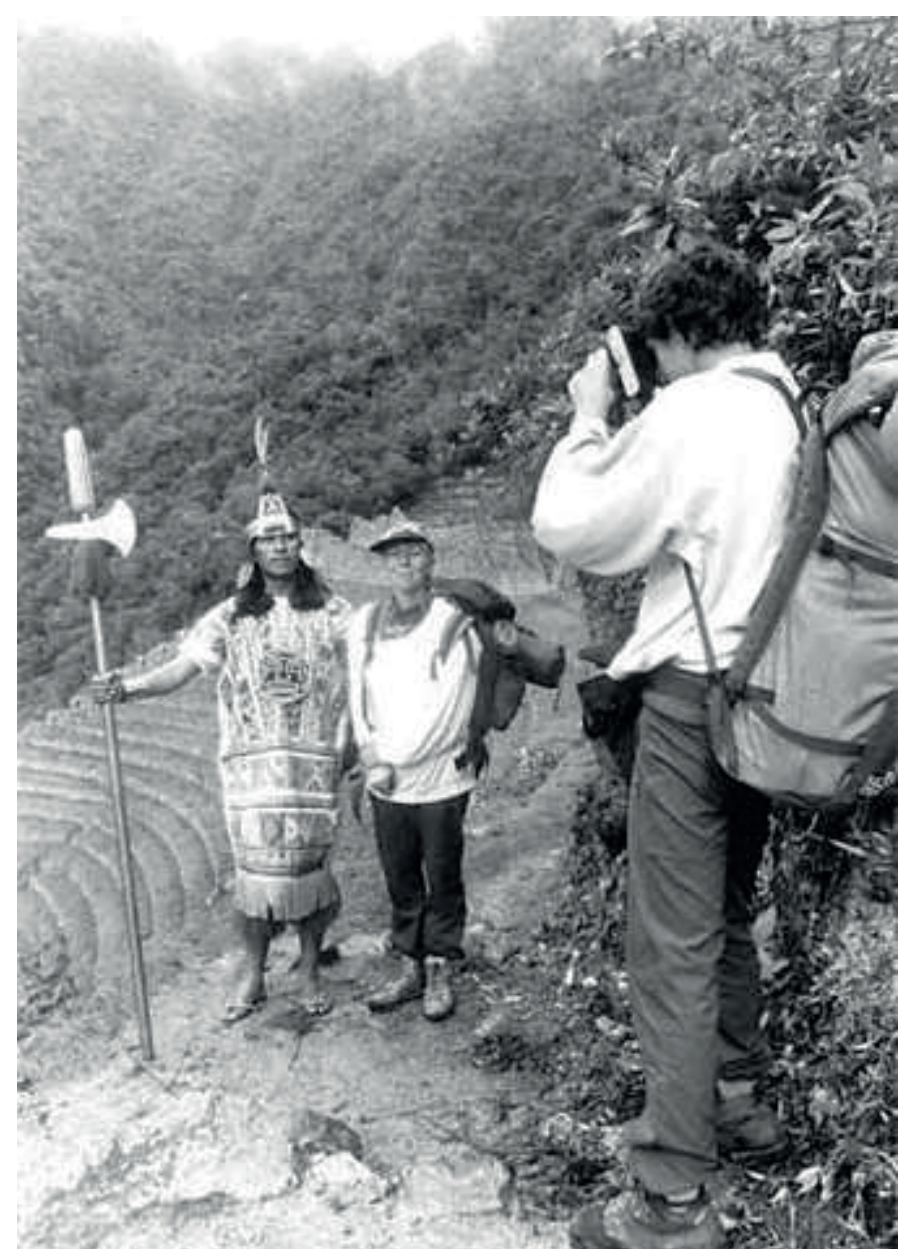

Figura 1. "La cordialidad y belleza escénica no bastan. El Perú sigue siendo un destino medio caro y medio malo." A pesar de haber sido tomada en 1996, esta imagen habla por sí sola. La circunstancia no ha cambiado. Foto de la revista Caretas. 
A juicio de muchos analistas, la cifra de 5 millones de visitantes que el "Plan Estratégico Nacional de Turismo"7 pretende traer al 2015 es irrisoria si la comparamos con el flujo de visitantes en países como España o México. A la vez, es excesiva dentro de nuestra realidad, y desatinada si se tiene en cuenta la fragilidad de muchos de nuestros recursos y enclaves turísticos, como es el caso de Machu Picchu que, al decir de los expertos, no resistiría por mucho tiempo un turismo masivo de tales proporciones. Y, peor aún, se ha cuestionado la política que se quiere aplicar para explotar las riquezas culturales y naturales del país -hay quienes advierten que esto último ya está sucediendo con, por ejemplo, las irregulares concesiones de algunos monumentos arqueológicos, como veremos más abajo-. Aún así, tanto las autoridades como los empresarios del sector hacen oídos sordos, pues únicamente parecen pensar en números y más números y nada más. A tono con esto, Alfredo Ferrero, ministro de Comercio Exterior y Turismo, informó el pasado martes 23 de agosto del presente año -2004- que en julio de 2005 se iba a presentar un ambicioso proyecto. El PENTUR, según palabras de Ferrero, "estará caracterizado por la descentralización, con una estrecha participación de los gobiernos regionales y con la elaboración de circuitos turísticos que involucrarán a dichas regiones. Lo segundo tiene como base el consenso entre el sector privado y el público. Y, lo tercero, que ahora sí hay recursos para su desarrollo, gracias al apoyo de la Corporación Andina de Fomento (que ya ha donado más de cien mil dólares) y del Banco Interamericano de Desarrollo, organismo con el que todavía se conversa sobre

\footnotetext{
7 PENTUR.
}

http:/ / www.mincetur.gob.pe/default.asp?pag=links/cuerpo2.htm\&lat=links/lateral.asp?pag=turismo\&num=4 03/9/04 
los montos que serán desembolsados, señalando, además, que su presentación oficial estaba prevista para julio de 2005."8

Sin embargo, parece que esto no será tan fácil y muchas serán las vallas a sortear para que este "plan" tenga éxito. Siendo, tal vez, la más importante, aquella que tiene que ver con la parte humana del turista, víctima, casi siempre de forma impune, de la desatención, la imprevisión, el maltrato y el desinterés hacia su persona y necesidades por parte de quienes aplican las políticas de Estado respecto al manejo de este sector, condiciones que también implican al sector privado. Entre la actitud y el comportamiento de los inversionistas privados, las políticas turísticas del MINCETUR ${ }^{9}$, los turistas y la relación de esta actividad económica con el entorno social donde se desenvuelve, parece estar el detalle. Por tales motivos es crucial considerar la incompatibilidad existente entre el supuesto de un "auge turístico" en el Perú -tantas veces pregonado por el Ministerio de Comercio Exterior y Turismo en boca de su actual titular, Alfredo Ferrero- y la pobreza en la que viven nuestros pueblos. Contra la previsión de que en el presente año -2004- se espera la llegada de un millón de visitantes "que van a dejar tantos millones de dólares", conspira una verdadera contradicción socioeconómica: no se trata de las cifras en cuanto a ingresos por turismo receptivo, sino del hecho de que tal "auge" sólo parece beneficiar a unos pocos en un país donde su ministro de Economía, Pedro Pablo Kuczynski, se dedica a "florear" -alabar, en términos peruanos- el "chorreo de dinero" que no es sentido por unos "muchos"... sino sólo por una elite.

Los puntos arriba señalados, sobre todo el referente a la parte humana del turista y la responsabilidad social, son, pues, el pie “cojo" del PENTUR, herencia tanto del MINCETUR como de quienes intervinieron en el diseño y elaboración -buenas

\footnotetext{
8 "Gobiernos regionales participarán en el diseño de Plan Turístico Nacional". Diario El Comercio. Miércoles 25 de agosto de 2004 http://www.comercio.com.pe/EdicionImpresa/Html/2004-08-24/ImpTemaDia0183141.html 03/9/04

${ }^{9}$ MINCETUR http://www.mincetur.gob.pe
} 
intenciones, todavía - de este "plancito", cuyos lineamientos analizaremos a lo largo de este reportaje. Todo pasa por los esquemas mentales del mundillo político -jefe de Estado, ministros, parlamentarios y demás yerbas del campo- y también por el sector privado dedicado al turismo. A esto se suman las taras sociales y estereotipos que la sociedad civil -especialmente de llamadas clases " $\mathrm{A}$ " $\mathrm{y}$ " $\mathrm{B}$ " (ver ** al final de este apartado) - viene arrastrando desde hace muchos años. Todo ello agravado por las deficiencias orgánicas, estructurales, y de la misma informalidad en que se ha venido desarrollando esta "industria sin chimeneas", causales precisamente de su atraso con respecto a otras actividades económicas del país.

\section{Zonas Turísticas por área geográfica}

1. Zona Nor-Oriental (verde): Tumbes, Piura, Lambayeque, La libertad, Ancash, Cajamarca, Amazonas, Loreto.

2. Zona Centro (rojo): Lima-Callao, Ica, Pasco, Junín, Huancavelica, Ayacucho, Ucayali, Huánuco.

3. Zona Sur (amarillo) Arequipa, Moquegua, Tacna Cusco, Puno, Apurimac y Madre de Dios.

Fuente: Ministerio de Comercio Exterior y Turismo - PENTUR. 


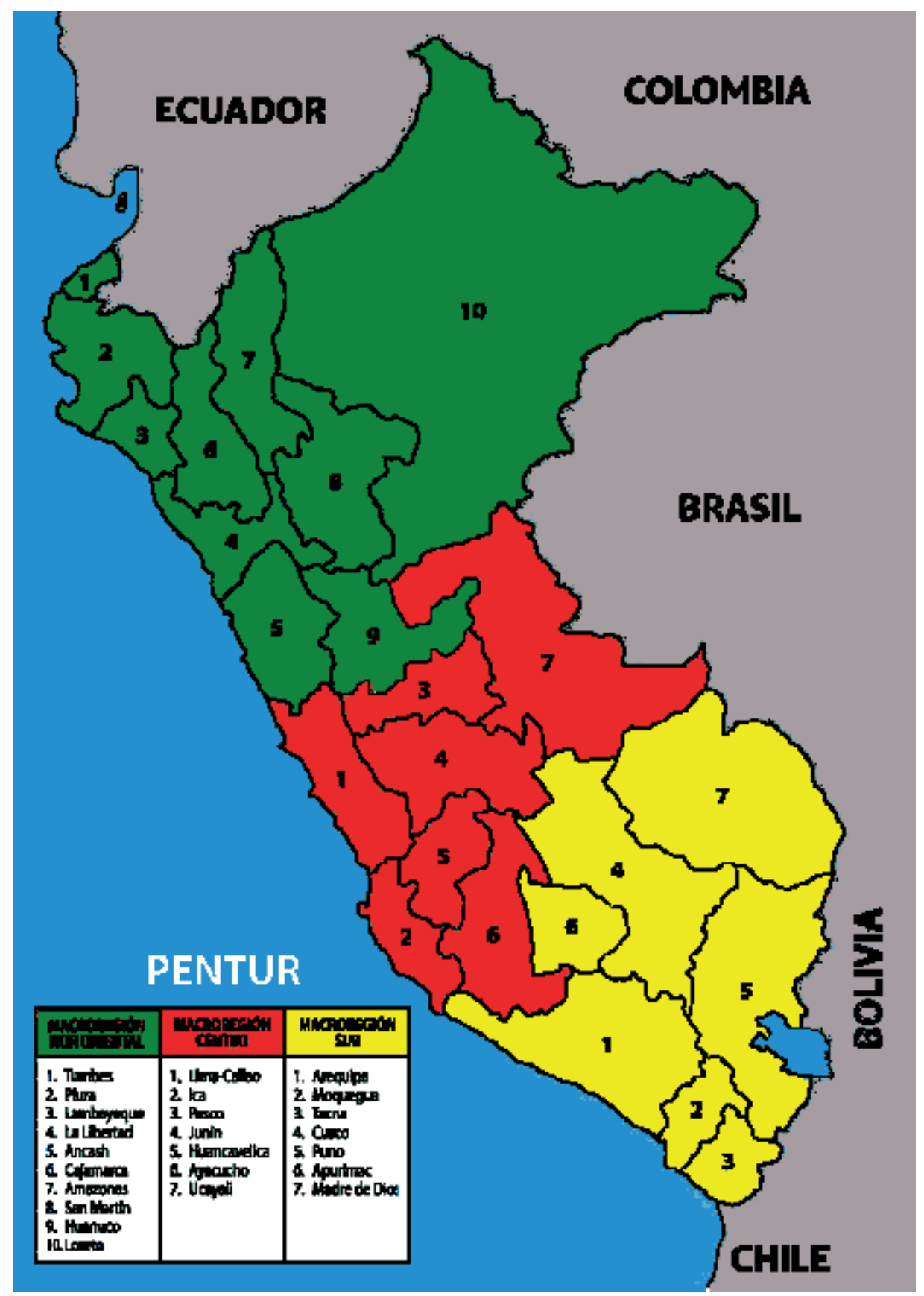

Figura 2. Mapa del Perú con las zonas geográficas identificadas por el PENTUR para el desarrollo de la futura política turística nacional -si es que éste se lleva a cabo-.

Esta situación ha colocado -inmerecidamente - al Perú en la cola de los países más atrasados en esta materia, muy a pesar del imán que representa para los visitantes, quienes llegan a nuestros aeropuertos atraídos por la fascinación, el embrujo y el 
enigma del país de los incas. Muchos de estos turistas, sin embargo, y a pesar de tantas maravillas, quedan desencantados cuando se topan con la desorganización imperante en este sector. A pesar de estas falencias, el turismo es actualmente la segunda fuente de divisas del país, después de la minería. Los visitantes siguen llegando, y así será siembre, pero no lo hacen por quienes dan servicios turísticos ni, mucho menos, por lo que pregonen las autoridades del sector, lo hacen por lo que significa el Perú. Y mientras no cambien las cosas, van a seguir llegando... a cuentagotas, no como pretenden decir las estadísticas "oficiales". Vienen para maravillarse con nuestras bellezas y se van desilusionados por la bajeza moral de muchos operadores turísticos y la pobreza de los servicios que brindan, no por la cantidad sino por falta de calidad humana. Quienes nos visitan no se decepcionan del Perú, sino de la forma como algunos peruanos les ofertan sus servicios turísticos y cómo los tratan. Ellos, los visitantes, no esperan necesariamente un servicio turístico de cinco estrellas, lo que quieren es una decencia de cinco estrellas. Este es el primer detalle.

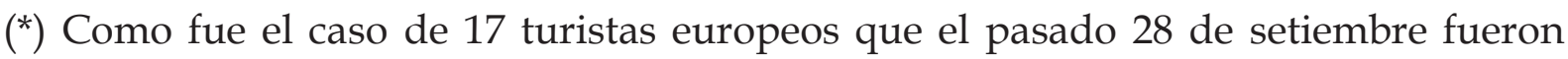
tomados como rehenes en el interior del famoso templo del Coricancha (Cusco) por una turba de campesinos cocaleros que protestaban contra el gobierno. Aunque todo no pasó de un susto, quedó la impresión de que muchas cosas tendrán que cambiar para que estos visitantes quieran regresar al Perú. Sugerimos revisar esta noticia en el siguiente enlace:

http:/ / www.elcomercioperu.com.pe/EdicionImpresa/Html/2004-09-

28/ImpTemaDia0199135.html 29/9/04

$\left.{ }^{* *}\right)$ Algunos sociólogos y sicólogos achacan esto a la educación, pero también al estrato socioeconómico o cultural del lugar de procedencia de quienes manejan o viven de esta industria sin chimeneas, o por otros factores. En todo caso, ya no es un secreto que en el "país de todas las sangres" cada vez más está dejando de mandar el 
apellido o la posición social o económica. También lo hace el crecimiento socioeconómico de muchos nuevos empresarios y ciudadanos procedentes de estratos más bajos, que han roto literalmente con la otrora rígida pirámide de la sociedad peruana, que todavía algunos insisten en apuntalar -como se puede observar entre líneas en algunos planteamientos del PENTUR -. Es evidente que los tiempos cambian. ¿También el turismo?

\section{Matando a la gallina de los huevos de oro...}

"Definitivamente no podemos conferir la categoría de establecimientos turísticos a quien no lo tienen. No es turismo la farsa, el trato grosero, la ducha que nunca funciona, la impuntualidad de un servicio incómodo o quedarse varado en un balneario porque no llegó el taxi contratado. No es turismo un museo que no tiene nada que exhibir y un sobreprecio en lo poco que se puede consumir. Como bien se ha reiterado hay que explotar al turismo no al turista."

Miguel Godos Curay ${ }^{10}$

La riqueza de los recursos naturales y culturales del Perú, aupada a su mágica aureola de misterio y leyendas doradas, qué duda cabe, siempre ha alimentado pasiones y desenfrenos para los viajeros de todo el mundo y de todas las épocas; $y$, como es de esperar, la codicia y el afán de lucro de empresas y empresarios vinculados, directa o indirectamente, con el turismo, son ahora los nuevos expoliadores, no ya del oro sino del patrimonio turístico de este país. Siempre se dijo que el Perú era y es como un relicario donde todos quieren meter la mano sin medida -o muchos de esos "todos"-, a cambio de poco o nada, como no nos vamos a cansar de reiterar.

${ }^{10}$ LOS TURISTAS, LAS MOSCAS Y EL SECO CHAVELO. Diario "El Regional" de Piura. http://elregionalpiura.webcindario.com/Miguel\%20Godos/godos_turistas.htm 06/9/04 
Entonces, ante el espinoso sendero que queda por recorrer, fiel a la prédica: "de buenas intenciones está sembrado el camino al infierno", el actual gobierno del presidente Alejandro Toledo, con el apoyo del Ministerio de Comercio Exterior y Turismo y entidades relacionadas con este sector, se propone llevar a cabo este "plancito" que, como señalan, aspira a dar facilidades a los turistas e incentivar la "inversión privada" -frasecilla ésta que en el Perú es la comidilla de los círculos empresariales y cultores del neoliberalismo-. Otro de los objetivos es establecer destinos turísticos alternos al ya saturado circuito Cusco-Machu Picchu (Nota 1), crear nuevos puestos de trabajo, construir caminos, brindar seguridad a los visitantes, proporcionar servicios eficientes, entre otras cosas. Hasta aquí, todo muy bien, pero...

Aquí mucho se habla de la "inversión privada" en turismo. Es como si se tratara de la divina pomada capaz de curar todos los males, pero, tal como están planteadas las cosas, y como las ha programado el PENTUR, no es así. Pocos parecen percatarse que para empezar un "plan" como éste, primero tienen que cambiar su actitud hacía el turista y dejar de pensar en él como si fuera una mina de oro. Este cambio también debe implicar una toma de conciencia sobre lo que significa la realidad de la pobreza. En el Perú hay operadores turísticos que practican una doble moral: mientras dicen que se promueve el turismo para traer desarrollo, le dan la espalda a la miseria y sólo se acuerdan de ella para utilizarla en beneficio propio. Una ambigüedad de conceptos y conductas que también parece haber contagiado al mismísimo gobierno. Esto es lo que parece ignorar el PENTUR (ver Capítulo 5. Por esta pata "cojea"). Aún les cuesta entender que los turistas no son mercancías, sino seres humanos que llegan al Perú para pasarlo bien. Son personas, no máquinas para llenar los bolsillos de operadores y agentes turísticos. Tampoco entienden que las gentes que ellos visitan en sus "tours" turísticos también tienen derecho a recibir un buen porcentaje de las ganancias por este concepto, toda vez que los visitantes son llevados a conocer 
recursos turísticos que se encuentran en sus propios pueblos, comunidades o regiones geográficas.

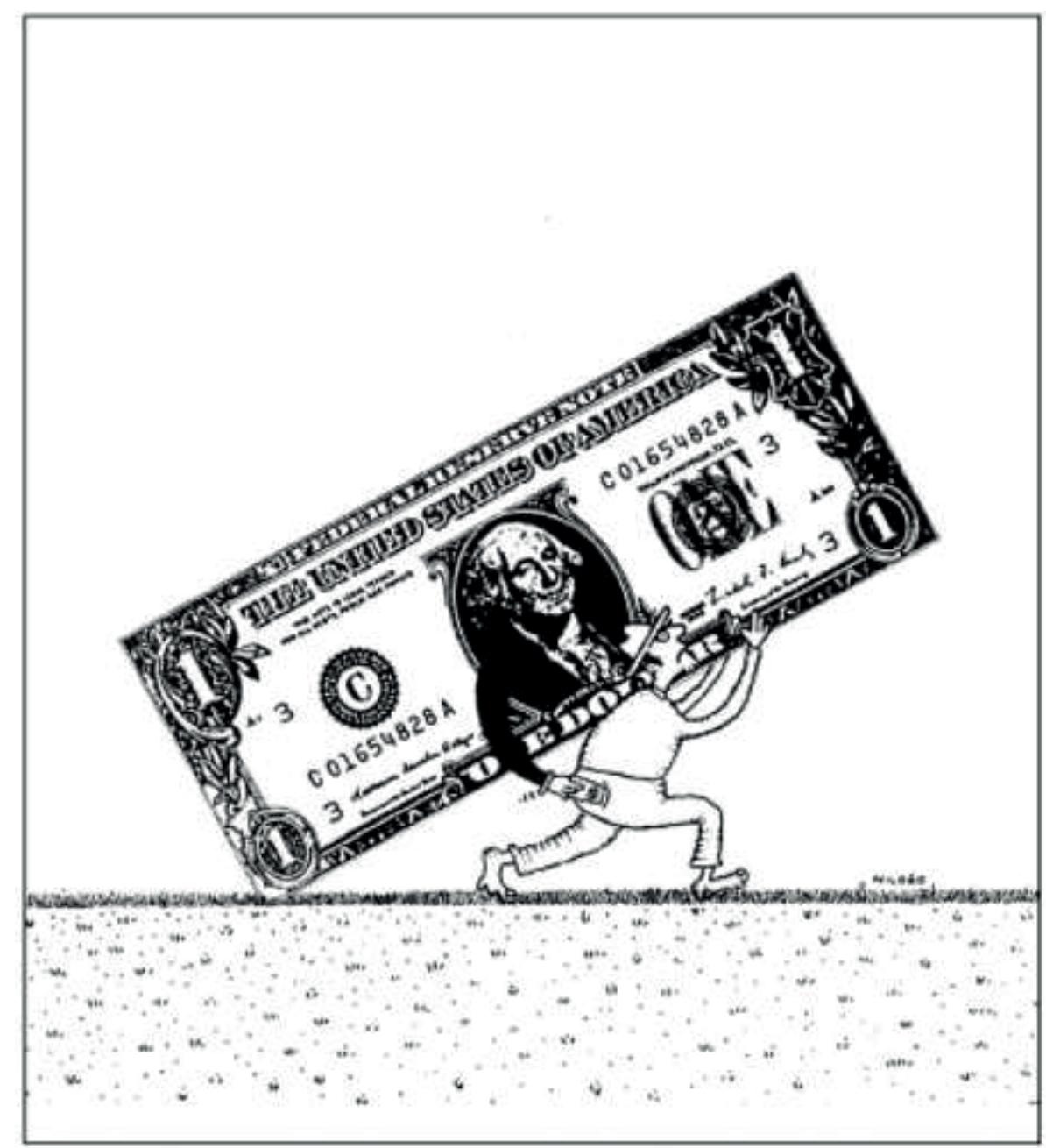

Figura 3. "Assim caminha a humanidade ao sul do Equador" (Así camina la humanidad al sur del Ecuador) Caricatura de Nildão, Brasil.

\subsection{Turismo sin rostro humano}

De Alfredo Ferrero, el actual titular del MINCETUR, sinceramente ignoramos si se trata de un demagogo profesional -de los tantos que abundan en nuestra política- o bien peca de iluso o cae en un exagerado optimismo al hablar de las presuntas "bondades" de "su plancito". Lo cierto es que desde el anuncio del PENTUR, en 
agosto pasado, no hace sino hablar y hablar como un loro del "enorme potencial turístico del Perú" como si creyera haber encontrado el cuerno de la abundancia, anunciando a los cuatro vientos "que caerán más visitantes", como si fueran mariposas a atrapar con una redecilla. Pero se equivoca de cabo a rabo si piensa que los turistas "van a caer" en "mancha" -en masa, como se dice-. La realidad es que en el Perú la organización del tinglado turístico es de llorar, pues ésta se ha convertido en una actividad extractora de dólares o euros -no nos vamos a cansar de decirlo-, donde todo comienza y termina con el abrir una billetera, sacar y sacar dinero, y dejar la "alcancía"... vacía.

De iluso peca también el doctor Ferrero cuando insiste -bajo su punto de vista y el de los diseñadores del PENTUR- que el Perú es el cuarto destino turístico para los europeos, sobre todo si tomamos en cuenta las estadísticas de la "Organización Mundial del Turismo"11, que no citan este país entre estos presuntos "destinos". La verdad, por más que duela, y esto es lo que el MINCETUR no quiere reconocer, es que ahora, tal como están las cosas, un turista europeo preferirá ir al Ecuador antes que al Perú. Pues aquí no hay un turismo en el sentido concreto de la palabra, sino una actividad dedicada extraer, a esquilmar... a los turistas, más que otra cosa. "Turismo", entonces, es mucho más que eso. El turismo al que alude el titular del MINCETUR es precisamente el turismo de "europeos ricos", que sino también de "americanos ricos". Es una actividad económica alienante y exclusivista a la que parece orientarse el PENTUR. Esto demuestra, una vez más, que en este país de absurdos y acomplejados, los empresarios turísticos y el mismísimo gobierno sólo piensan en el amor al chancho o a los chicharrones y, por si esto fuera poco, aquí hay una exacerbada fascinación por todo lo que tenga aroma de "American Express" o "Master Card". Si en el Perú un turista no reúne cierto "perfil" financiero -tiene que ser "rico" o tener un ingreso familiar respetable, además de poseer tarjetas de crédito,

${ }^{11}$ Organización Mundial del Turismo WTO

http://www.world-tourism.org/espanol/newsroom/Releases/2004/junio/data_sp.htm 17/9/04 
o ser -o parecer- de "clase A-1", entre otras "finezas"-, entonces, éste no entra en los planes de la "inversión privada", menos de la "promoción turística" que pretende implantar el PENTUR. Vale decir... bajo tales argumentos y pretextos quieren convertir a nuestro turismo en una actividad para "privilegiados", descartando a quienes no tienen la capacidad adquisitiva para realizar grandes consumos. Literalmente, se quiere obligar a los turistas a cumplir con estos parámetros. Se trata de una condición donde no entra la mayoría de los viajeros, como es el caso de los llamados "mochileros" y también los turistas nacionales, grandes negados de la industria sin chimeneas en el Perú.

Que no se diga, pues, que el gobierno peruano promueve el turismo interno cuando decreta feriados fuera del calendario, pues este "turismo" suena más bien a "engañamuchachos" para quienes gustan viajar cerca de sus ciudades -como es el caso de los empleados y jubilados del sector público y el de muchos trabajadores de la actividad privada-. Y, encima, tener que toparse con los sinvergüenzas que dicen ser operadores o agentes turísticos, quienes amparados en un marco legal obsoleto e impreciso, en la indiferencia y desidia de las autoridades (in)competentes, terminan por estafar a sus clientes, convirtiendo un viaje de placer en un verdadero atentado contra la dignidad humana. (ver testimonios de turistas frustrados en el Capítulo 6. Quejolandia, la voz del turista es la voz de Dios...)

Si bien el Perú es uno de los destinos más atractivos del mundo, esto no se refleja, como ya señalamos arriba y lo haremos a continuación, en las estadísticas sobre destinos ni flujos turísticos de la "Organización Mundial del Turismo" debido precisamente a estas y otras deficiencias que los involucrados en el sector no quieren reconocer. Son ellos mismos, los representantes de la "inversión privada" y el propio MINCETUR la causa de que un visitante ya no quiera regresar más al Perú y, la próxima vez que haga un viaje turístico, nos "pase por encima" y se vaya para otra parte. Países en teoría "más atrasados turísticamente" que el Perú, e incluso vecinos, 
están pisándole ya los talones al ego de la administración del presidente Alejandro Toledo, a su presuntuoso ministro de Comercio Exterior y Turismo. Constituyéndose esto en un dolor de cabeza para quienes han diseñado el PENTUR. Países "chicos" como Ecuador (ver Nota 2) constituyen una cabal demostración de cómo puede funcionar, y muy bien, una política turística eficiente y sin tanto "irse por las ramas".

Se engaña, pues, a la opinión pública, a los turistas y a los organismos internacionales, cuando el gobierno peruano, representado en este caso por el MINCETUR, muestra también, con bombos y platillos, cifras y datos estadísticos del turismo en color azul -estos, por cierto, dudosos-, para justificar las grandilocuentes afirmaciones del titular del sector turismo. Sin embargo, se olvida del factor humano de esta "industria sin chimeneas" y de los turistas. No se trata sólo de sumar ingresos, sino también de restar ineficiencias propias del sistema. Y esto no lo percibe el turista, como el ciudadano de a pie no percibe el tan voceado "chorreo" de dinero en sus bolsillos. Calidad humana, buen trato, no abusar de su poder adquisitivo esquilmarlo-, respetar su privacidad, no acosarlo ni perseguirlo, dejarlo escoger, no inventarle tarifas absurdas, proteger su salud, cuidarlo: eso es lo que en realidad quiere el turista que viene al Perú. Y van a seguir viniendo, pero, al margen de números y estadísticas, maquilladas o no, muchos se van a ir para no volver más, porque en otras partes se van a sentir más personas que en el Perú.

Los "expertos" en la materia, para explicar el problema de la actividad turística en el Perú, han recurrido a diferentes fórmulas como los análisis de mercado, a las cifras, al término "inversión privada", al "merchadising", a las dificultades organizativas, a la infraestructura deficiente, etc. Sin embargo, ni uno ni otro. Por más que se busque una explicación, siempre quedará la impresión de que "algo falta". Porque lo que nadie quiere aceptar es que quien realmente falla, y hace fallar todo lo demás, son los esquemas mentales y educativos del factor humano, el mismo que parece no formar 
parte de la agenda del futuro "Plan Estratégico Turístico Nacional" como una coyuntura que debe ser tomada en cuenta.

El punto, entonces, no es sólo la "inversión privada": hay que promover e invertir, sí, pero tanto como esto debe importar el "ser humano" -el turista en su particularidad-, que es el destino final adonde va dirigido el producto de dicha inversión. Y, como los anteriores conceptos, debe importar igualmente el "cómo" se está haciendo dicha inversión. Además, tenemos que romper al absurdo del libertinaje a ultranza, donde los empresarios turísticos siempre hicieron lo que les ha dado la gana, sin importarles para nada la parte humana de los turistas ni sus necesidades. En un país donde persisten estas incongruencias y fracasan todas las políticas turísticas, tanto ellos -los empresarios- como los políticos han demostrado su ineptitud para manejar esta "industria sin humo", que en lugar de traer desarrollo, está trayendo más caos y menos turistas. No cambiar la actitud de los agentes y operadores turísticos frente a quienes visitan el Perú, más aún, ante los turistas nacionales, los grandes "convidados de piedra" de la actividad turística, es condenarse a vivir siempre en el atraso y al margen de los mejores destinos del mundo-. Seguir viviendo la utopía de un tinglado turístico que parece diseñada solo para "ricos" extranjeros y, de paso, ignorando la realidad social en la que viven millones de peruanos, es como tratar de tapar el Sol con un dedo.

\subsection{El "síndrome" del sitio "exclusivo"}

Hay empresarios que invierten cientos de miles de dólares con la idea de que los visitantes van a llegar para gastarse todo su billete; es más, algunos se dan ínfulas de tener sangre azul, al pretender "exclusivizar" el rubro turismo. Pero, craso error. Sucede como en la calle Miguel Dasso, en el distrito limeño de San Isidro ${ }^{12}$. Este lugar

${ }^{12}$ Municipalidad de San Isidro. http:// www.msi.gob.pe 05/9/04 
no tendría nada de especial si no fuera por un curioso "fenómeno de finanzas somáticas" o, peor aún, "masoquismo empresarial" -sinceramente no sabemos si tildarlos así, o bien, considerarlo como un caso digno de ser estudiado en el diván de un sicoanalista-. Resulta que esta pintoresca calle, de sólo dos manzanas y media, escondida y recoleta, es, para mala suerte de unos, un sinónimo de maldición contra los establecimientos gastronómicos de cinco estrellas y cuatro tenedores. Y eso a pesar de la pretendida aureola de "sitio exclusivo" que algunos otorgan a este rincón limeño.

Miguel Dasso, desde su nacimiento, siempre ha sido un lugar que ha vivido con el "Cristo de espaldas", como dijo un escritor peruano. Aquí ya la llaman "la calle de la indigestión financiera" pues, crónicamente, al poco tiempo de ser inaugurado un restaurante "top"... quiebra. Lujosos y extravagantes, estos locales casi nunca han tenido éxito. A los vecinos de la zona ya se les ha hecho costumbre constantes obras de remodelación y mudanzas de tiempo en tiempo. Salvo raras excepciones, no hay año en que esto no suceda. La historia siempre ha sido la misma: poco antes de cerrar definitivamente, estos locales, en primer lugar, comienzan a ofrecer menús baratos, impensables para su "exclusividad"... o, para evitar el "roche", la vergüenza, simplemente cierran sus puertas sin mayor explicación que la de unos letreritos donde dice "local en remodelación" o "local fumigado" o, "próxima reapertura". Luego, un buen día, desaparecen las mesas y las sillas, se esfuman los rótulos, y las vidrieras son de pronto cubiertas con cartones y pintura blanca. Nadie dice nada hasta que el establecimiento recibe una radical transformación y reabre con otro nombre y otro dueño. $\mathrm{Y}$ así han pasado desde locales de comida china, hasta "trattorias" italianas, pasando por comida peruana e internacional, e incluso fuentes de sodas. Todos han terminado diciendo "good by".

El problema es que aquí hay hombres de negocios que no se dan cuenta, o no quieren hacerlo, de que lo que los lleva al fracaso es la actitud que adoptan respecto al 
negocio y se olvidan que no es la inversión, sino los clientes quienes lo mantienen vivo, los mismos a los que se mantiene lejos por los precios exagerados que cobran. $Y$ esto es lo que está sucediendo con todo restaurante que se da presunciones, sin merecérselos, de ser un lugar "exclusivo".

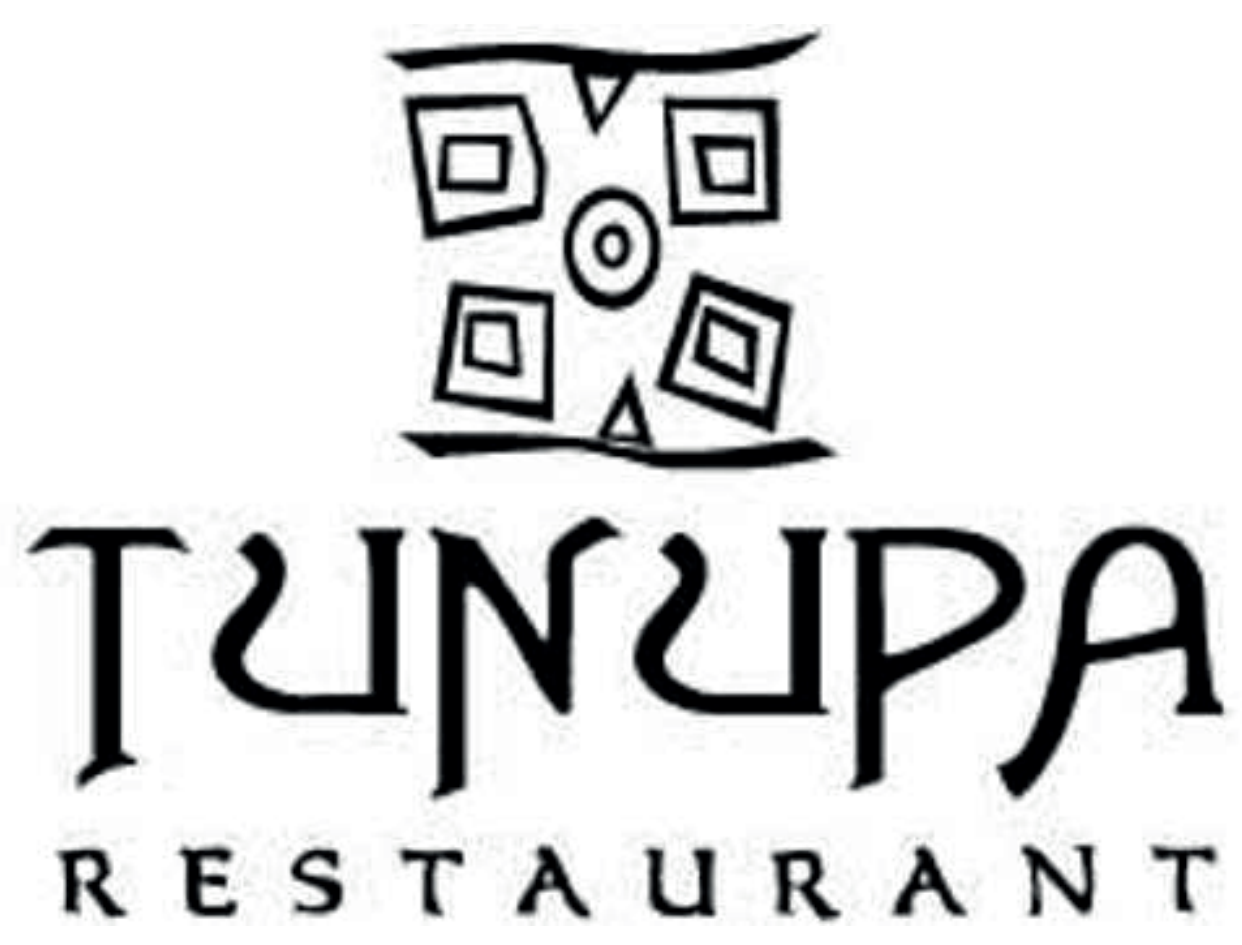

Figura 4a. Logotipo del restaurante "Tunupa". Ilustración obtenida de las "Páginas Amarillas" de Telefónica del Perú. 


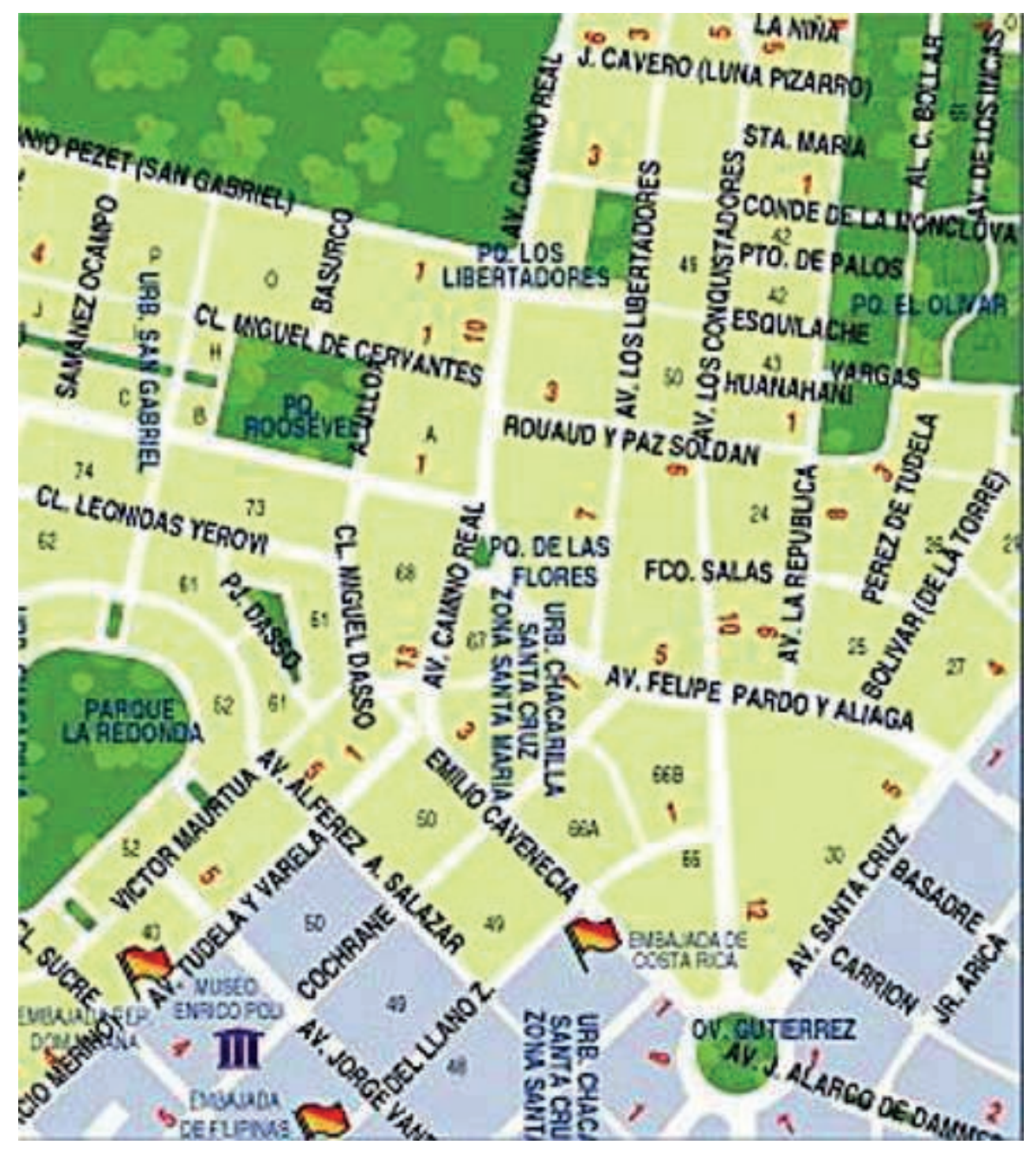

Figura 4b. Plano de la zona de ubicación del "Tunupa", en San Isidro (Lima), donde se puede apreciar, al centro, la calle Miguel Dasso. Ilustración Obtenida de las "Páginas Amarillas" de Telefónica del Perú.

Actualmente, el restaurante de lujo "de turno" en esta calle es el "Tunupa"13. Este lujoso establecimiento, a pesar de la inversión que sus dueños hicieron, parece estar siguiendo el destino de otros. Desde que fue abierto en el 2001, este elegante local parece sumirse en la modorra del vacío. Mesas adornadas con flores, velas, servilletas decoradas y cubiertos finos, esperan a unos clientes que pasan y pasan...

${ }^{13}$ Tunupa. http:// www.viabcp.com/travel/DetallePSO.asp?CODPROD=66 03/9/04 
camino de la competencia: el "Delicasse", una cafetería-pastelería ubicada cerca de allí. ¡Es el único lugar de este tipo que parece haber tenido éxito en esta calle... hasta ahora! Y no por ser un lugar tan exclusivista -aunque está siempre lleno de "pitucos", gente frívola y platuda - sino por sus precios cómodos y la calidad del servicio que allí se brinda. Y, mientras esto sucede, los únicos parroquianos del "Tunupa" son los turistas llevados allá en tours organizados por agencias de viajes elitistas y hoteles de cuatro o cinco estrellas; son clientes que pagan sus consumos en dólares o euros. Aparte de los turistas, casi nadie viene por aquí. Se nota a las claras que la "exclusividad" de este lugar ha puesto en fuga a la mayoría de potenciales clientes. Ni siquiera los "pudientes" de San Isidro o Miraflores -los distritos más ricos de Lima-, se animan a entrar. Y si entran una vez, no lo hacen dos veces, y terminan yéndose para el "Delicasse", cuando ven las tarifas que tienen, pues, además del consumo, cobran por cubiertos, por cada fruta que utilizan para los jugos, por el pan "de cortesía"... entre otras cosillas más, "inflando" con ello sus exageradas cuentas.

\subsection{Lo que no quiere el turista}

Sirva esto como una simple moraleja para entender lo que pasa con los servicios turísticos en el Perú. Los comensales son, entonces, como los turistas. Y estos, generalmente, llegan al Perú con sus propios presupuestos de viaje, y no van a hacer, necesariamente, grandes consumos, ni van a esperar que los acosen para que lo hagan; menos que los esquilmen -cosa que es ya una costumbre en este país- y, tampoco, que los "asalten" literalmente llegando a un aeropuerto o terminal terrestre o ferroviario, cualquiera que sea. Tampoco esperan que se les echen encima para ofrecerles tal o cual servicio o chuchería a precios exorbitantes, y menos que lo "sangren", como se dice. El turista lo que desea es que lo respeten, que lo dejen disfrutar tranquilo de su viaje, que le cobren precios justos, que para eso va o viene. (Nota 2) 
Por otro lado, aquí se tiene la creencia generalizada de que todo extranjero es un rico millonario o trae muchos billetes. Se trata de una falacia por asociación, alrededor de la cual se ha levantado todo un tinglado turístico diseñado únicamente para recibir a estos "gringos con plata", marginando a otros turistas que, sin tener tanto dinero, también dejan lo suyo. Este "turismo de ricos" es precisamente una de las causas del atraso en que se encuentra esta actividad económica en el Perú. Los "otros turistas", los que no son precisamente "platudos", pese a ser la gran mayoría de visitantes, son ignorados tanto por las políticas estatales del sector como por los operadores turísticos privados. Y en los estudios de mercado sólo figuran como "otros" para resaltar su aparente "intrascendencia", aunque hay vivos del MINCETUR que los suman a las estadísticas totales -de turistas llegados al Perú- para inflar ese "auge turístico" del que tanto se vanaglorian las autoridades del sector. Sin embargo, estos visitantes son, realmente, verdaderos turistas. Principalmente se trata de "mochileros" o amantes de la naturaleza y los deportes de aventura, como el parapente, las caminatas por viejos senderos precolombinos, el montañismo o el ciclismo a campo traviesa. Y con ellos vienen también muchos vacacionistas, parejas en luna de miel, matrimonios, jubilados, y hasta grandes grupos y familias enteras. Y esto a pesar de que algunos "especialistas en la materia", que se las creen todas, se empeñan en minimizar groseramente esta hermosa faceta del turismo, tal vez porque estos visitantes suelen venir por cuenta propia, o traídos por empresas turísticas extranjeras, y no representan un ingreso "interesante" para las cuentas bancarias de los operadores turísticos.

Y lo paradójico de esto es que muchos de estos turistas aventureros son los que más se preocupan por el medioambiente y por la gente de los pueblos que visitan, y en sus viajes muchas veces terminan haciendo algo de labor social. Se trata de personas que no entienden eso de "exclusividades" y son los clientes más exigentes a la hora de tomar un servicio, siendo, igualmente, los que más reclaman una mejor atención para el turista. Ellos, por su filosofía de vida y forma de ver la actividad turística, son 
también los que más se estrellan contra el sistema establecido, aunque esto no significa que los que sí participan del turismo "exclusivista" no pasen también las de Caín, por culpa de malos operadores turísticos y peores servicios. Pues a ellos también les duele en el bolsillo los abusos que se cometen en nombre de la industria sin chimeneas.

\section{FICHA TÉCNICA DEL TURISMO EN EL PERÚ (2004)}

¿Quiénes van pa'1 Perú a conocer la tierra de los Incas? No es el turismo, sino los turistas quienes mueven al turismo. Mucho más que cifras y personas que viajan...

... de los extranjeros que nos visitan:

$34 \%$ son mujeres

$66 \%$ son varones

... de la edad:

$17 \%$ tiene entre 15 a 24

$32 \%$ tiene 25 a 34 años

$21 \%$ tiene 25 a 44 años

$17 \%$ tiene 45 a 54 años

$13 \%$ de 55 a más

... del país de procedencia:

26\% de América del Norte (21\% de EEUU)

$26 \%$ de Europa (5,01 de Reino Unidos)

39,7\% de América del Sur (14,8\% de Chile)

... de la permanencia promedio en el País:

15 días 
... del ingreso familiar anual de los visitantes:

$24 \%$ entre US\$ 15.000 y US\$ 35.000

21\% entre US\$ 35.000 y US\$ 60.000 (¿Y el otro 50\%?) (1)

... ellos realizan turismo de tipo:

urbano......... 93\%

cultural........ 70\%

naturaleza.... $47 \%$

aventura...... 36\%

vivencial...... 32\%

... un turista gasta en el Perú un promedio de:

unos US\$ 78 diarios

... los ingresos por concepto de turismo:

en 2003, US\$ 932 millones

... llegada de turistas al Perú:

1999: 894.094

2000: 800.491

2001: 801.334

2002: 865.602

2003: 933.643

2004 (hasta julio): 437.802 (2)

... los más educados:

$82 \%$ de los turistas tienen educación superior

... ¿dónde van?: 
92\% a Lima

$52 \%$ a Cusco

47\% a Machu Picchu

$30 \%$ al Valle Sagrado de los Incas

$35 \%$ a Puno

$28 \%$ a Arequipa

17\% al Valle del Colca (Arequipa)

... El PBI (4) de rubros económicos del Perú (5):

4.597 Minería

923 Turismo

821 Pesca

... los más de Latinoamérica (2003):

México: 18.700.000

Brasil: 4.091.000

Argentina: 3.374 .000

Chile: 1.514 .000

Perú: 933.543 (3)

Ecuador: 759.000

... los más en el mundo (2003):

Francia: 75.000.000

España: 52.500.000

Estados Unidos: 40.400 .000

Italia: 39.600 .000

China: 38.000 .000

Reino Unido: 24.800 .000

Austria: 19.100.000 
México: 18.700 .000

Alemania: 18.400 .000

Canadá: 17.500 .000

... Sí que se quejan

en el año 2003 las 15 oficinas de Información y Atención al turista de PromPerú recibieron...

1.772 reclamaciones, se realizaron 7.165 asesorías.

el $57 \%$ de las quejas fue contra de empresas de transporte aéreo

el $27 \%$ contra agencias de viajes

el 13\% contra empresas de transporte terrestre

el $2 \%$ contra servicios de hospedaje

El 78\% de los turistas dijo que recomendaría a sus amigos y parientes visitar el Perú. (6)

\section{NOTAS DE LA TABLA}

1. ¿Se evidencia aquí la exagerada importancia que se da en la actividad turística receptiva a los visitantes de mayores recursos, negando su lugar al otro porcentaje de turistas, cuyos ingresos no llegan a dichas cifras? Lo cierto es que este dato no hace sino confirmar la limitada visión de nuestros empresarios turísticos, peor aún, de quienes quieren promover el PENTUR, que tan bajo concepto tienen de los visitantes conocidos como "mochileros" y los que practican el turismo de aventura. Por cierto, hay otros indicadores que parecen corroborar esta apreciación, como es el caso de los hoteles (ver sub capítulo 3.2. ¡Oh, Machu Picchu! - Figura 9. La paradoja de los hospedajes en el Perú... ¿Un turismo mayoritariamente rico?) 
2 - 3. Concedemos al amable lector el beneficio de la duda, por cuanto hace poco se denunció que el gobierno peruano viene manipulando cifras y datos estadísticos oficiales para fines políticos o de propaganda proselitista; aún así, el dato correspondiente al Perú es el más aproximado que se tiene.

\section{Producto Bruto Interno.}

5. Datos del Banco Central de Reserva (2003)

6. Pero hay otro $22 \%$ que no opinó así, y eso es una mala señal, pues, según los más modernos estudios de marketing, por cada cliente insatisfecho, se pierden 20.

Fuentes: MINCETUR - El Comercio ${ }^{14}$ - INEI ${ }^{15}$ - BCR 16 - Diario "Hoy" de Quito17 WTO

\subsection{El "otro" turismo}

Así, pues, a pesar de los inconvenientes creados por un sector turístico más orientado a extranjeros "platudos" -definitivamente una minoría - que a otro tipo de actividad similar, ellos hacen sus propios itinerarios, adoptan sus propias previsiones, y vienen al Perú prescindiendo de los dichosos "servicios turísticos". Ellos mismos escogen o reservan sus hospedajes y, para los tours, en lugar de contratar agencias turísticas "oficiales", se los organizan por su cuenta con la ayuda de guías o personas de su confianza, o agencias turísticas independientes que les inspiren seguridad. Y dejan sus buenos dividendos al fisco, sin que nadie los presione. Pero los operadores

\footnotetext{
${ }^{14}$ Diario "El Comercio" - Lima. http:/ / www.elcomercio.com.pe 17/9/04

${ }^{15}$ Instituto Nacional de Estadísticas INEI. http:/ / www.inei.gob.pe 17/9/04

${ }^{16}$ Banco Central de Reserva. http:// www.bcrp.gob.pe/ 17/9/04

${ }^{17}$ Diario "Hoy" de Quito (Ecuador)

http:// www.hoy.com.ec/NoticiaNue.asp?row_id=184168 17/9/04
} 
turísticos los ignoran, como ya dijimos, y los ponen en el último lugar de la actividad turística, pues no pueden "explotarlos" como ellos quisieran. Los chicos son muy listos y saben cuidarse... de los "vampiros". Éste es otro punto que en el Perú no se quiere entender.

No cabe duda que la armazón comercial levantada en torno a esta actividad económica, en vez de acoger al turista, lo atemoriza. Se hace evidente que aquí, para los agentes y operadores turísticos peruanos, el fin justifica los medios: su óptica es que el turismo es una actividad extractora de dinero, como si se tratara de una mina, a cambio de poco o nada, y ello -no nos cansa repetirlo- en medio del caos, la desorganización, la improvisación y la inseguridad casi totales.

Y conste que estamos hablando de un tipo de "comercio turístico" que se ha convertido en toda una perniciosa institución -para algunos esto es una verdadera enfermedad social-, basado en la persecución solapada, el acoso, el abuso y el fastidio, como ya veremos capítulos abajo. Hay la impresión de que los peores enemigos del turismo en el Perú son precisamente éstos... quienes deberían ser sus mejores aliados: los operadores turísticos y las agencias de viajes y sus intermediarios, y todo ante la indolencia institucionalizada de las autoridades y organismos como el Ministerio de Comercio Exterior y Turismo, el autor del futuro PENTUR; "plancito" este que más parece diseñado para empresas y empresarios turísticos "ricos" o para cierto tipo de extranjeros con billetes, marginando a un gran segmento de esta actividad, que no "cumple" con los "requisitos" del sistema: no son de "clase A-1" o "VIP". (ver Nota 2).

\section{Machu Picchu a trancas y barrancas}

"Los elevados costos harían pensar que Cuzco es una región opulenta: en el Valle Sagrado una noche de hotel supera los 100 dólares; el ingreso al nuevo Museo de 
Arte Precolombino está a 25 soles; llegar a Macchu Picchu desde Aguas Calientes, incluyendo el obligatorio viaje en micro, cuesta 29 dólares a un extranjero y 19 a un peruano. Si calculamos que Machu Picchu recibe más de 200.000 visitantes al año, la mayoría extranjeros, comprenderemos que se trata de millones de dólares."

Wilfredo Ardito Vega 18

Uno de los aspectos más peliagudos de esta problemática es lo que desde hace tiempo viene sucediendo en el Cusco y en Machu Picchu. Hoteles, agencias de viajes, discotecas, restaurantes, empresas de transportes, entre otros, se apiñan en las estrechas calles de la antigua capital del imperio inca, sin orden ni concierto, convirtiendo a esta urbe en una suerte de desordenado bazar oriental. Por otra parte, se sabe que un promedio de 1.000 turistas diarios llega para visitar estos lugares. La sobre oferta y la excesiva demanda se han saturado tanto que han puesto en peligro los restos arqueológicos de Machu Picchu y otros monumentos de esta región.

En el caso de Machu Picchu, hace poco la UNESCO ${ }^{19}$ puso el grito en el cielo cuando se enteró que la excesiva explotación turística de estas ruinas estaba poniendo en peligro la integridad del monumento (Notas 3 y 4). Poco después del desastre natural provocado por las lluvias en la zona de Aguas Calientes (ver capítulo 15. Recortes de Prensa II), este organismo internacional le dio un año de plazo al gobierno peruano para que hiciera algo, pues se había denunciado que las estructuras monumentales de este enclave arqueológico se estaban deteriorando (ver * al final de este apartado), de otro modo, Machu Picchu dejaría de ser considerado parte del "Patrimonio Cultural de la Humanidad", todo por culpa de la irresponsabilidad de las autoridades -en especial de la filial Cusco del Instituto Nacional de Cultura INC ${ }^{20}$ -

\footnotetext{
18 "Cusco: Esplendor y miseria". http:// www.adital.org.br/site/noticia.asp?cod=9929\&lang=ES 10/9/04

${ }^{19}$ UNESCO PERÚ. http://www.comiunesco.org.pe/ 06/9/04

${ }^{20}$ INC. http:// www.inc.gob.pe 03/9/04
} 
y de empresarios turísticos peruanos. A los meses de esta advertencia, (Nota 5) todavía no se ha tomado cartas en el asunto. Mientras tanto, los turistas siguen llegando en masa, sin control alguno, traídos al Perú por operadores turísticos que no reparan en nada para preservar este patrimonio sin copia.

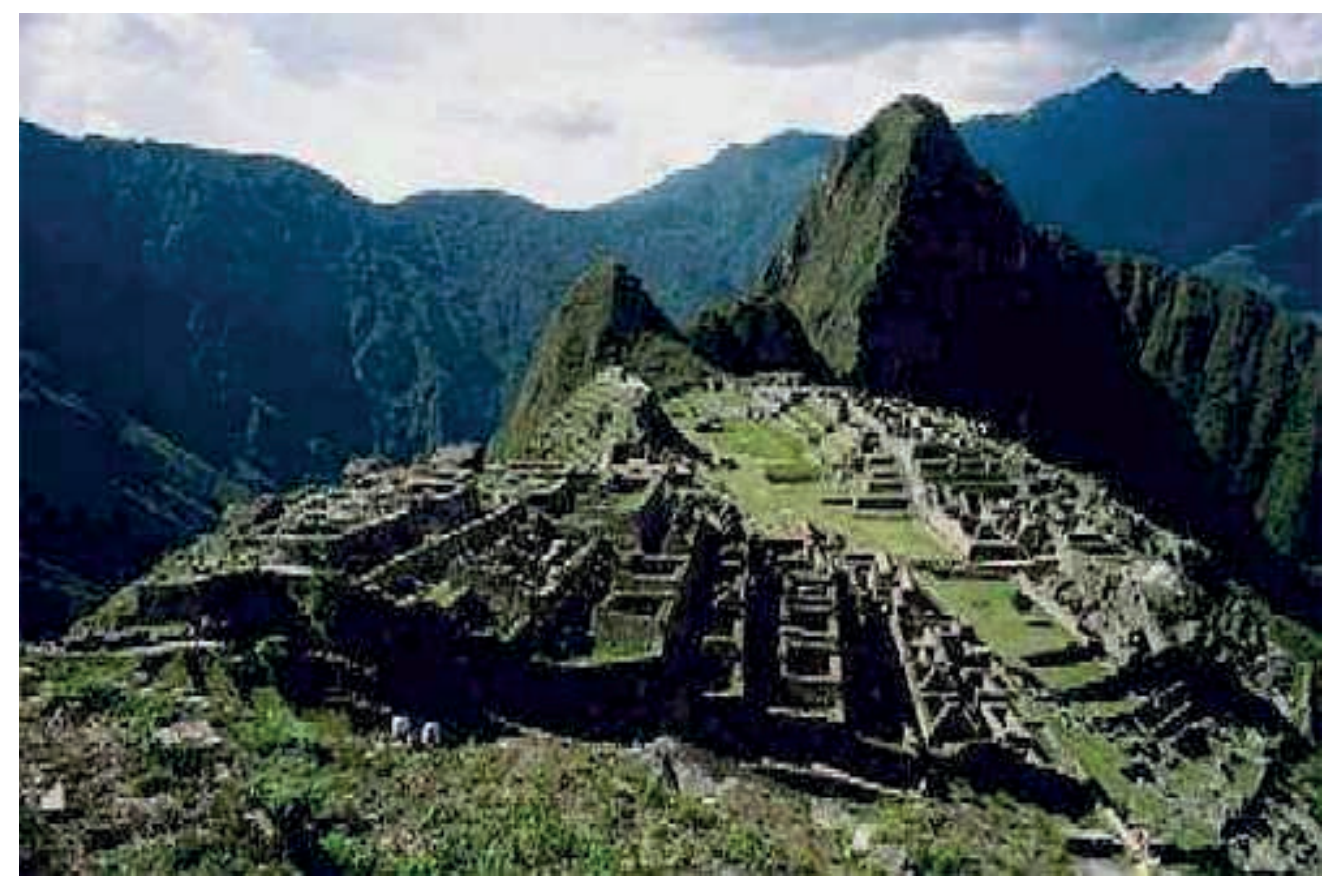

Figura 6. Majestuosa panorámica de la ciudadela inca de Machu Picchu, en una foto de Lizardro Távera. Portal "Arqueología del Perú". Argentina. 


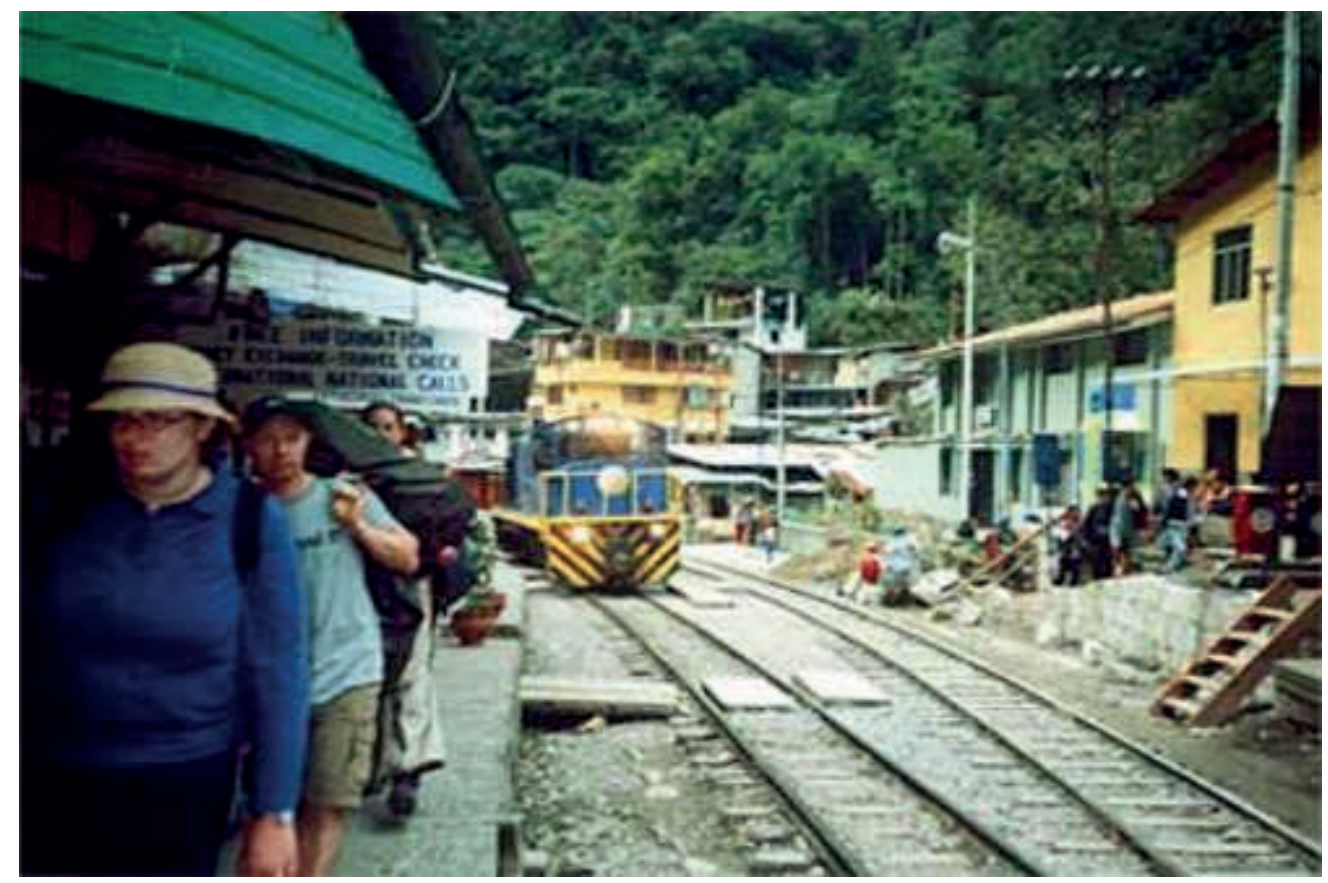

Figura 7. La estación de Aguas Calientes, paso obligado para todo turista que vaya o venga de Machu Picchu. Foto de Patrícia Bagdonas. Portal "Lugares do Mundo". Brasil.

El movimiento turístico se ha convertido en una actividad frenética en varios puntos del país. Es un "negocio" casi esquizofrénico, donde los usuarios son sólo monedas de nuevos soles o billetes de dólar que van a ganar los prestadores de servicios turísticos. El objetivo, es, pues, captar la mayor cantidad posible de visitantes, arrancándoselos incluso a la competencia. Hay agencias de viajes que ofrecen al turista distintas alternativas y paquetes para visitar el Cusco, nuestro principal destino, pero cobran precios abusivos por los pasajes aéreos que venden -la excusa son las "comisiones" que cobran por cada pasaje de avión-. Hay viajeros que terminan comprando sus boletos en las mismas aerolíneas -que no son ningunas santas, tampoco-, espantados por las tarifas de estas agencias, algunas muy conocidas como "Lima Tours"21 o "Nuevo Mundo"22.

\footnotetext{
${ }^{21}$ Lima Tours SA. http://www.limatours.com.pe/ 05/9/04

${ }^{22}$ Agencia de Viajes Nuevo Mundo (Lima, Perú) http://www.gruponuevomundo.com.pe/ 05/9/04
} 
El libertinaje empresarial -fruto este del fracasado neoliberalismo del corrupto gobierno del ex dictador Alberto Fujimori-, y la falta de control y reglas claras en la actividad turística, ha dado pie al surgimiento de todo tipo de empresas turísticas, sobre todo en el interior del país y algunas en Lima, que, al parecer, han entendido el negocio a su manera. Éstas, en vez de brindar al visitante un servicio confiable y eficiente, con calidad y buen trato, se han convertido en verdaderas aves de rapiña al acecho de las billeteras de los viajeros, no otra cosa (Ver ** al final de este apartado), tanto o peor que los delincuentes que merodean para asaltarlos. No ven, pues, a las personas, solo les interesa el dinero y se olvidan de lo demás.

$\left(^{*}\right)$ Es de notar que tras esta llamada de atención, las autoridades peruanas lograron convencer a la UNESCO que las célebres ruinas no corrían peligro.

http:/ / www.embperu.org.br/M\%20Picchu\%20texto.htm

(**) Y qué decir de enclaves como las Líneas de Nasca o Machu Picchu, donde, al parecer, los empresarios turísticos han entendido que son sitios como "Copacabana Beach", en Río de Janeiro..., es decir: turismo de masas y calculadora en mano además de un banco al frente-, y nada de cuidado por el patrimonio cultural ni por la calidad del servicio turístico que se presta.

\section{1. ¡Oh, Machu Picchu!}

Un caso patético -¿o patológico?- del acoso que sufren los turistas en el Perú es el "show" que se observa a diario en los traslados del Cusco a la ciudadela inca de Machu Picchu. Este suele realizarse mediante el sistema denominado "cerrojo" o "bus - tren", modalidad adaptada a un turismo masivo, que permite traslados rápidos de 45 minutos hasta estas célebres ruinas, cuando el viaje normal en auto vagón dura unas 3 horas. Lo que nadie dice es que en los autobuses contratados por los 
operadores turísticos para llevar a los visitantes hasta Ollantaytambo, punto donde se abordan los trenes que van hasta la estación de "Puente Ruinas", la procesión viaja por dentro. Hay unas señoritas que, con el pretexto de vender guías o manuales para turistas, cobran abusivamente por unas simples hojas de papel impreso de mala calidad -ojo para los que ignoran esto-, cuyo contenido no tiene pies ni cabeza, con todos los datos de historia y geografía de la zona del Cusco equivocados.

Después, en el tren de Ollantaytambo a Puente Ruinas ${ }^{23}$, otras féminas presionan insistentemente a los turistas para que les compren productos importados. ¡No te dejan en paz! ¿Por qué tratar de venderle un chocolate "Snickers" a un gringo o una cerveza "Heineken" a un alemán, y casi al triple de lo que cuesta en sus propios países? En cualquier parte, un turista va a buscar siempre algo típico de ese lugar, ¿verdad? ¿Cuál es, entonces, la lógica, si lo que yo quiero hallar en México son "tacos mejicanos", no "arroz con pollo", un sabroso plato peruano aderezado con culantro, a menos que quiera buscar un lugar de comida peruana? Recuerdo un viaje que hice al Cusco hace ya algunos años. Cuando quien escribe estaba en el tren a Machu Picchu, mientras disfrutaba el paisaje, una "terramoza" se me acercó ¡diez veces! para ofrecerme tal o cual chocolate o colonia o whisky importados. No nos oponemos a que se vendan estos productos. Vender, sí, pero "sin abusar de la "gentileza", oye...". ¡De cualquier forma, pues, quieren sacarte la plata!

${ }^{23}$ Perú Rail (Ex ENAFER PERÚ SA) http:/ / www.perurail.com/ 07/9/04 


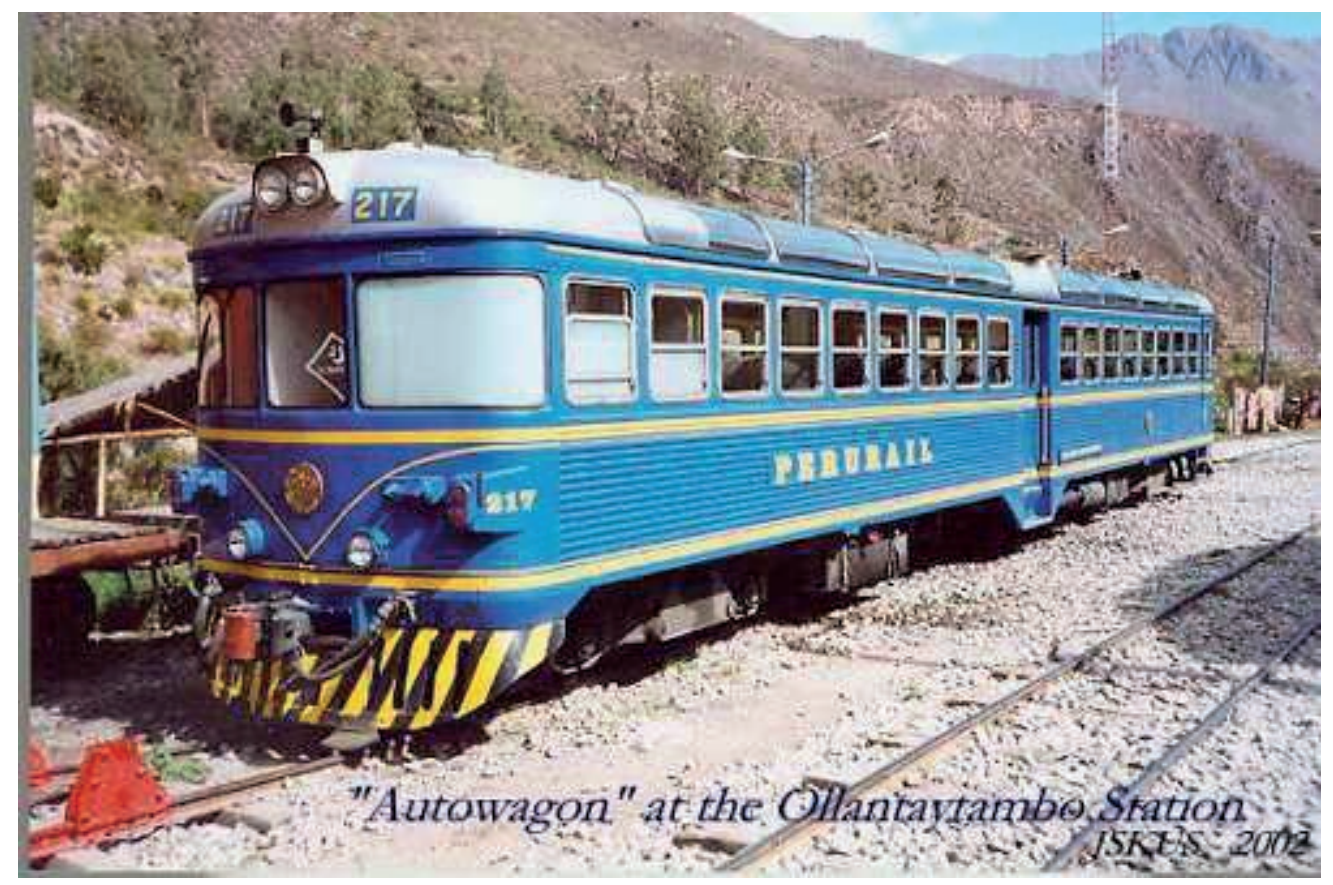

Figura 8. Hoy como ayer, los turistas viajan a Machu Picchu en estos viejos auto vagones, reciclados por la empresa Peru Rail, formada tras la privatización de la antigua ENAFER Perú. Foto de James Kus Vita. (USA)

Otro tanto ocurre con los servicios turísticos indirectos. Por ejemplo, hay artesanos y hay "artesanos": los primeros son los verdaderos, no viven del turista. Los segundos, serán artesanos y muy buenos, pero más parecen ser emisarios de las agencias de viajes y operadores turísticos... por lo que cobran, es decir, un ojo de la cara por un torito de arcilla del pueblo de Pucara (Puno), o por un poncho de alpaca de Huancayo (Junín). En la zona del Cusco bulle una pujante industria artesanal muy requerida por los turistas. Pero hay una diferencia abismal entre quienes ofertan sus productos en las inmediaciones de los restaurantes "A-1" y los lujosos hoteles del centro de esta ciudad y las artesanías del barrio de San Blas, mundialmente célebre por la creatividad de grandes artistas de la terracota y la arcilla. El colorido mercado del pueblo de Pisac, en pleno Valle Sagrado de los Incas, camino a Machu Picchu, es un lugar que goza del aprecio de los visitantes, pues aquí se puede encontrar la mejor artesanía de la región del Cusco y al alcance de todos los bolsillos. A la mayor parte 
de estos artesanos no los manipula el negocio turístico. La diferencia, tanto en lo cualitativo como en lo cuantitativo, salta a la vista.

La paradoja de los hospedajes en el Perú... ¿un turismo mayoritariamente de ricos?

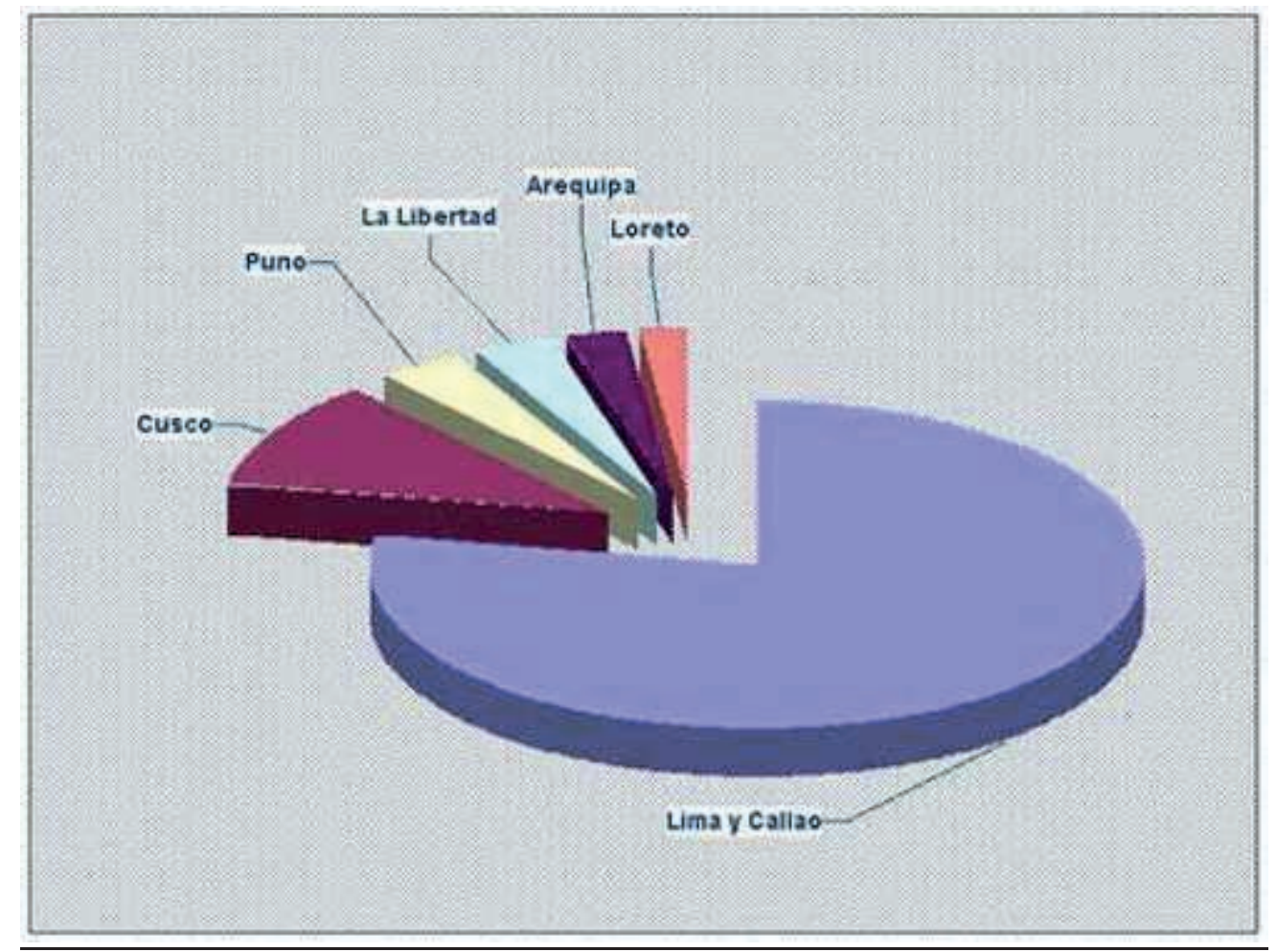

Figura 9a. Hoteles 5 estrellas por ciudad, año 2001 


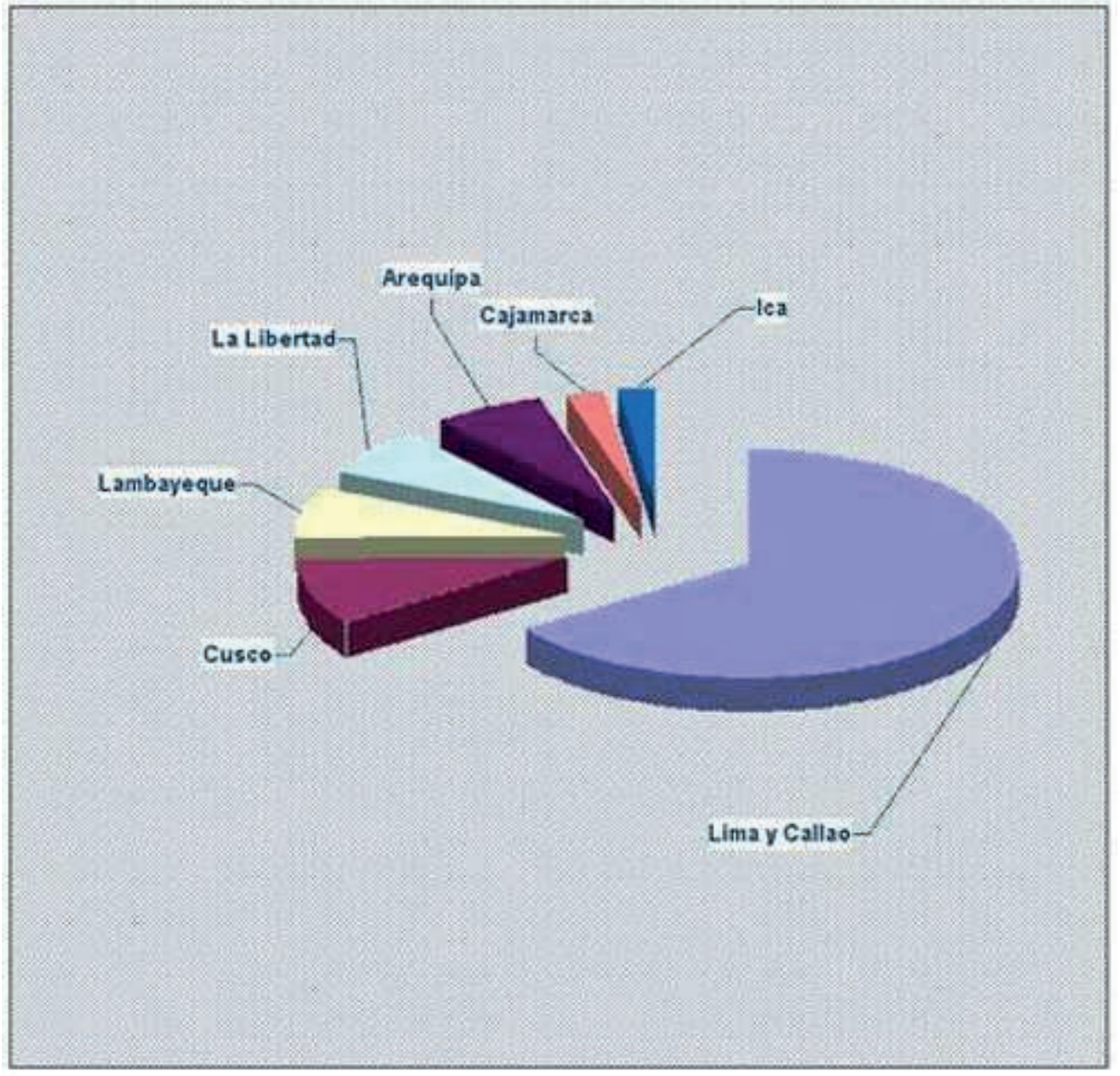

Figura 9b. Hoteles 4 estrellas por ciudad, año 2001 


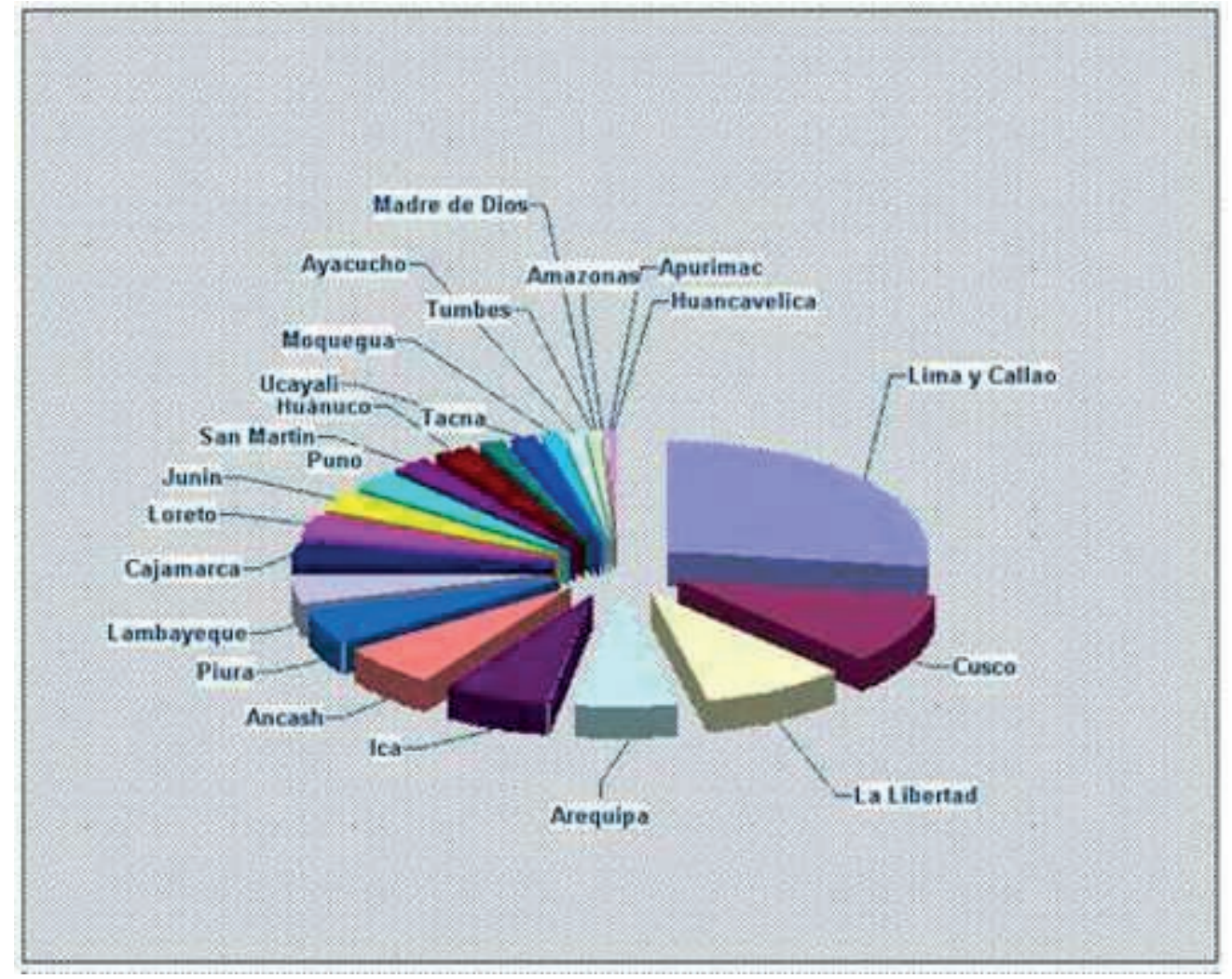

Figura 9c. Hoteles 3 estrellas por ciudad, año 2001

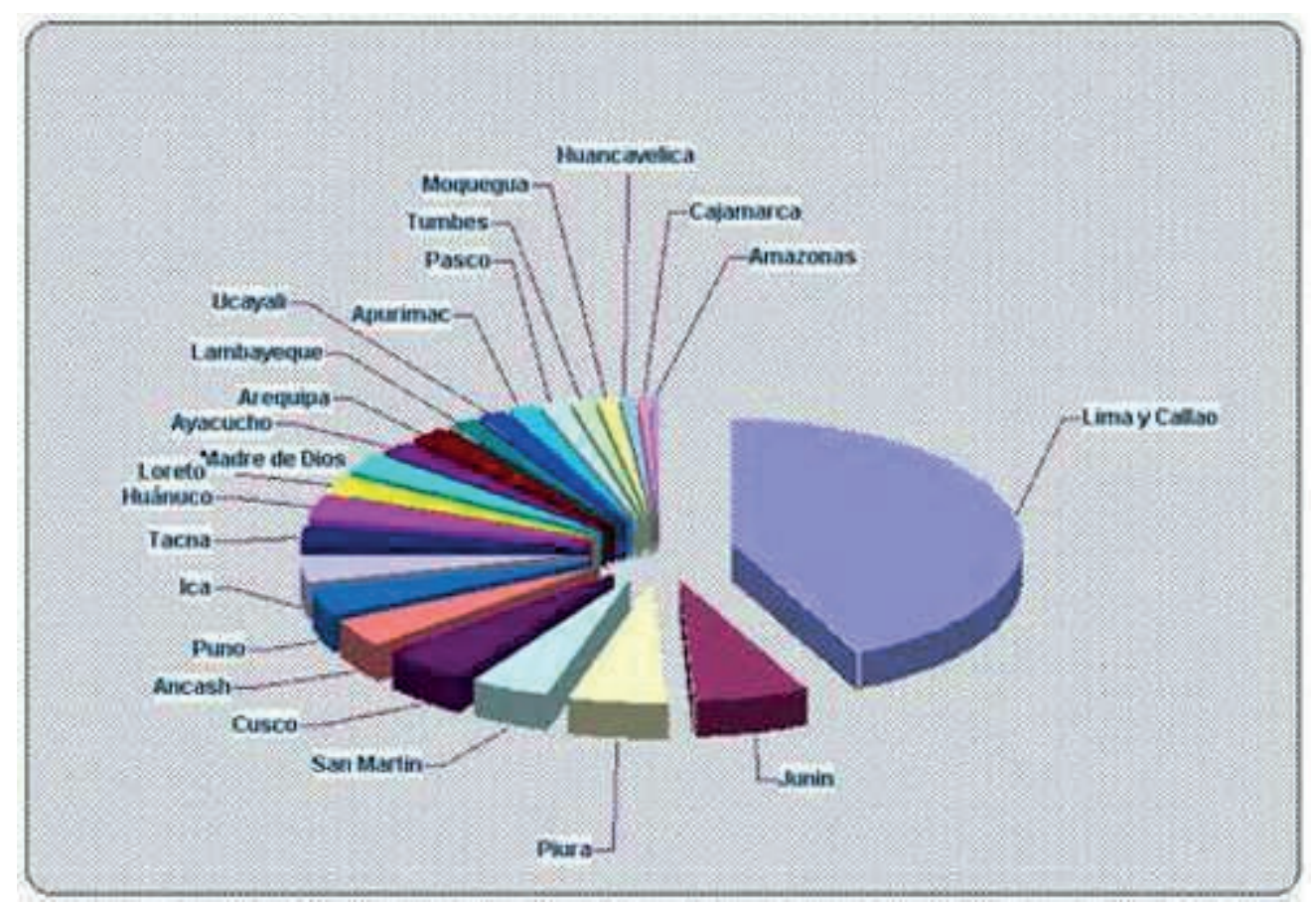

Figura 9d. Hoteles no clasificados por ciudad, año 2001 
Tal como se aprecia en los cuadros de arriba, en el Perú existe una sobreoferta de hoteles de 4 y 5 estrellas ( 9 a y $9 b$ ) en desmedro de otros hospedajes de menor categoría, como los de tres estrellas (9c) y los "no clasificados" (9d), es decir, sin "estrellas". Aunque esta información, disponible en el portal del Ministerio de Comercio Exterior y Turismo del Perú, se encuentra desactualizada desde hace tres años, es harto elocuente.

\section{2. ¿Turista o "pan con pescado"?}

Otra historia es la de los "City Tours" organizados por los hoteles -generalmente los de cuatro o cinco estrellas - o agencias turísticas, especialmente por Lima o Cusco. Para un turista amante de la gastronomía peruana, esto puede ser una pesadilla. Como la mayoría de los visitantes extranjeros sólo utiliza Lima como lugar de paso a ciudades del interior como Iquitos, Cusco, Arequipa o las Líneas de Nasca, y suelen quedarse apenas dos o tres días en la capital peruana, entonces hay "City Tours" que han sido "amoldados" a los paquetes "relámpago" de sólo cuatro o cinco días en el Perú. Como parte del itinerario de viaje, estos "City Tours" llevan a los visitantes a determinados restaurantes, previamente escogidos a conveniencia de quien brinda estos servicios.

El problema, aquí, es que estos tours los llevan casi siempre a los sitios más caros. Se ha criticado mucho a los organizadores de estos "City tours" pues no reparan en lo que piensa el viajero. Además de decidir el itinerario por ellos, no le proporcionan otras alternativas de adonde ir -hay operadores que literalmente se han encasillado en sus tours y no aceptan cambios-. Les importa un bledo saber si tal o cual lugar al que les quieren llevar les parece costoso o no. Ni menos les muestran las tarifas que cobran en el lugar adonde los llevan. Simplemente los desinforman para que no tengan la oportunidad de comparar y escoger lo más conveniente. La excusa para 
esto es la premura del tiempo, pues los visitantes sólo suelen estar "de tránsito" por Lima".

También se aduce que los operadores turísticos sólo llevan a sus clientes a los restaurantes que les ofrecen más descuentos, pero lo cierto es que tales descuentos no son para los viajeros. Total: el negocio redondo es entre los ofertadotes de paquetes turísticos y los servicios indirectos -los restaurantes - que responden a sus intereses y que también reciben su tajada. Aquí el turista es sólo un "pan con pescado" entre quienes se comen... su billetera. Y así, los visitantes tienen que aguantársela, a menos que se salgan del tour que están siguiendo -o viajen "a la aventura", por su cuenta - , aunque generalmente suelen desistir de ello, pues los operadores turísticos acostumbran disuadirlos al hablarles de lo peligroso que es caminar por Lima, y cosas por el estilo. Y lo hacen con premeditación, ventaja y alevosía, aprovechándose no sólo de la mencionada premura del tiempo, sino también de la ignorancia del extranjero sobre cuál lugar es más conveniente para su economía, pues en esto hay mucha desinformación.

Ante ello, no nos queda otra que preguntarnos si de verdad los operadores turísticos son o no conscientes de su actitud, como empresas, ante el turismo, o si, de hecho, conocen lo que realmente desea o necesita un turista que llega a Lima por unos días y se preocupan por su total bienestar. Lo cierto es que en el Perú, nada está garantizado en el sector turismo, ni siquiera los grandes hoteles de cuatro o cinco estrellas la tienen tan fácil. En este país, un turista debe cuidarse de los "choros" ladrones- y de los operadores turísticos; es más, tiene que estar "mosca" para que no lo "ensarten" con un tour que lo va a comprometer a realizar desembolsos no deseados. Esta reflexión parte de la premisa de que no todos los turistas quieren ir, necesariamente, a un lugar por lo que cuesta un plato a la carta o por ser éste un sitio VIP o tener cuatro o más cubiertos, sino, más bien, por la calidad y la sazón de la cocina peruana o internacional. 
¿Y esos lugares tienen que tener necesariamente cuatro o cinco estrellas para demostrar su categoría? La experiencia nos dice que el hecho de que un local tenga tantas estrellas no significa que éste sea bueno, eso hay que comprobarlo; y no necesariamente hay que pagar precios altísimos para poder saborear la mejor comida peruana o de cualquier parte. Pero, lamentablemente, la mayoría de los empresarios turísticos no lo piensan así. Sólo ven en esto una actividad extractora y nada más.

Otro tanto sucede con los hoteles, sobre todo los de 4 y 5 estrellas y algunos de 3 . La mayoría de estos alojamientos están habitualmente coludidos con las agencias de viajes u operadores turísticos... y los taxistas de ciertas empresas de transporte, sobre todo los encargados de la "recepción" y traslado a hoteles ya programados por quienes manejan el negocio o el tour. Se trata, pues, de un verdadero círculo vicioso: cuando un visitante llega al Aeropuerto internacional Jorge Chávez, de Lima24, por ejemplo, sobre todo si es europeo o estadounidense, los taxistas "amablemente", casi lo toman por asalto y lo obligan, o tratan de obligarlo, a ir al alojamiento al que ellos quieren llevarlo, generalmente al más caro, o le ofrecen varias alternativas, todas previamente seleccionadas a conveniencia, claro, de los vendedores de estos servicios. El comportamiento de estos taxistas se debe a que los hoteles u operadores turísticos les pagan por cada cliente que logran "pescar" en el aeropuerto y llevarlo a sus hospedajes o agencias turísticas.

\section{Una "aventura" en Cajamarca}

"La Empresa no se hace responsable por los problemas respiratorios de los pasajeros". Leyenda de los "boletos turísticos" de la agencia de viajes "Cumbemayo Tours".

\footnotetext{
${ }^{24}$ Aeropuerto Internacional Jorge Chávez. Lima - Perú.
} http://www.lap.com.pe/ 08/9/04 
No se necesita ser pitoniso para adivinar la pobreza mental y moral de algunos empresarios del ramo turístico, y menos la negligente permisividad e indiferencia, sumada a la desidia de autoridades irresponsables y muchas veces cómplices, que nunca están donde se les necesita, pero sí lo están para la ladronería, la borrachera y la coima. Es tal la falta de sentido en la actividad turística peruana, que llega al insulto.

Hay empresarios turísticos sin escrúpulos, muchos del interior del país y no pocos de Lima, que someten a los visitantes a verdaderas odiseas de sufrimiento y angustia cuando los embarcan en sus tours fuera de zonas urbanas debido a las condiciones en que se está prestando el servicio. Tal precariedad hace que el visitante se sienta inseguro al no saber si podrá contar con una ayuda, la mínima, aunque sea, en caso de presentarse una emergencia. Y conste que aquí no estamos hablando de adrenalina pura, propia de un turismo de aventura, de mochileros, mayoritario en el país, que también sufre la pasión de Cristo, a su escala, claro está, cuando se topan con uno de los aludidos... sangradores de bolsillos que no esperan encontrar en su camino. Aquí estamos hablando de lo que sucede en los sitios donde el largo brazo -y la mano- de Lima no llegan -o lo hacen de vez en cuando-, y esto ocurre incluso en lugares muy visitados, donde hay agencias cuyo negocio principal son los paseos por zonas arqueológicas, parajes naturales y pueblos pintorescos.

Para nadie es un secreto que hay destinos donde los visitantes son tratados como meros sacos de papas, pero muchos se lo callan por miedo o por desgana; en los tours del interior del país, los turistas suelen viajar hacinados en incómodas y destartaladas unidades móviles, manejados por quienes sólo esperan colmarse de billetes, sin importarles para nada el cómo están los turistas, ni si están cómodos o apretujados. Nada. Y si alguien, de pronto, tiene un problema de salud... mala suerte pues... 
Esto fue lo que nos pasó a mi esposa y a mí durante nuestras vacaciones del verano pasado -primera quincena del mes de enero de 2004- , cuando fuimos de paseo a la ciudad de Cajamarca ${ }^{25}$, en la hermosa sierra norte del Perú. En la Plaza de Armas de esta ciudad hay unas agencias que ofrecen paseos turísticos por la ciudad y cercanías, muy bonitos. Tienen los mejores guías turísticos de la zona, pero estos son dirigidos por empresarios que parecen no entender la diferencia entre una persona y una maleta. Estas empresas utilizan para el servicio que prestan unas camionetitas, tipo "kombi", nada aparentes, para trepar a los lugares adonde llevan a los turistas, que, aparte de ser incómodas, no suelen tener extintores, menos aún, el más elemental de los botiquines, para enfrentar lo que suele presentarse a veces en paseos de altura o al campo. $\mathrm{Y}$ eso teniendo en cuenta que Cajamarca se encuentra a casi 3.000 metros sobre el nivel del mar, superior a la altitud a la que están acostumbrados a tolerar la mayoría de los turistas que llegan al Perú.

\subsection{Valga un "paseíto"}

A nosotros nos habían informado que la mejor agencia de paseos turísticos en Cajamarca era la empresa "Cumbemayo Tours SR. Ltda." De modo que confiamos en dicha "recomendación" y contratamos un paseo a Cumbemayo ${ }^{26}$, un paraje idílico que está ubicado a unos 20 kilómetros de Cajamarca y a una altura de 3.510 metros sobre el nivel del mar, famoso por sus bosques de piedras y un increíble acueducto de factura prehispánica que hasta ahora intriga a los arqueólogos. Allí supimos lo que significan estos "paseos" en tales condiciones... de "atención al turista". Ya en plena "puna", lejos de la civilización, mi señora sufrió un sofoco y parecía que se ahogaba. En un comienzo me asusté pero, gracias a Dios, se le pasó al poco rato. Continuó el paseo y vino la extenuante caminata de tres horas por el maravilloso

\footnotetext{
${ }^{25}$ Cajamarca. http:/ / www.cajamarca.net/ 07/9/04

${ }^{26}$ Cumbemayo. http://peru.gotolatin.com/spa/Attr/htm/Peru-Cumbemayo.asp 07/9/04
} 
bosque de piedras y el célebre acueducto precolombino, tallado en la roca viva, que discurre cual río artificial. "Lleva el agua pa' Cajamarca...", me decía un guía que nos levantaba el ánimo a Pieri y a mí para seguir caminando, cuando las fuerzas ya nos habían abandonado, hasta las camionetas de regreso a la ciudad.

Poco después, cuando revisé los boletos que habíamos comprado en "Cumbemayo Tours" para dicha excursión, pude leer, en letras pequeñitas y disimuladas, la siguiente frase: "La Empresa no se hace responsable por los problemas respiratorios de los pasajeros". De puro confiado no me había fijado en este detalle. Vale decir, uno se podía morir en el camino y nada. Me preguntaba, entonces: ¿tanto cuesta llevar a bordo siquiera un balón de oxígeno pequeño con su mascarilla para paliar un aprieto a semejante altura, toda vez que no falta quien suele sufrir los estragos del soroche o mal de altura? ¡Con cuánta razón, en algunos hoteles de las sierras peruanas -aunque en muy pocos, por desgracia-, se suele invitar a los visitantes a un mate de coca (Nota 6), la hoja maravillosa del antiguo Perú, o se les invita a consumir una tableta de coramina!... que la tienen que comprar en una farmacia. Pero, no, aquí, en Cajamarca, no hubo nada de eso. Y eso que nosotros habíamos llevado nuestra coramina desde Lima, pero la olvidamos en el hotel. 


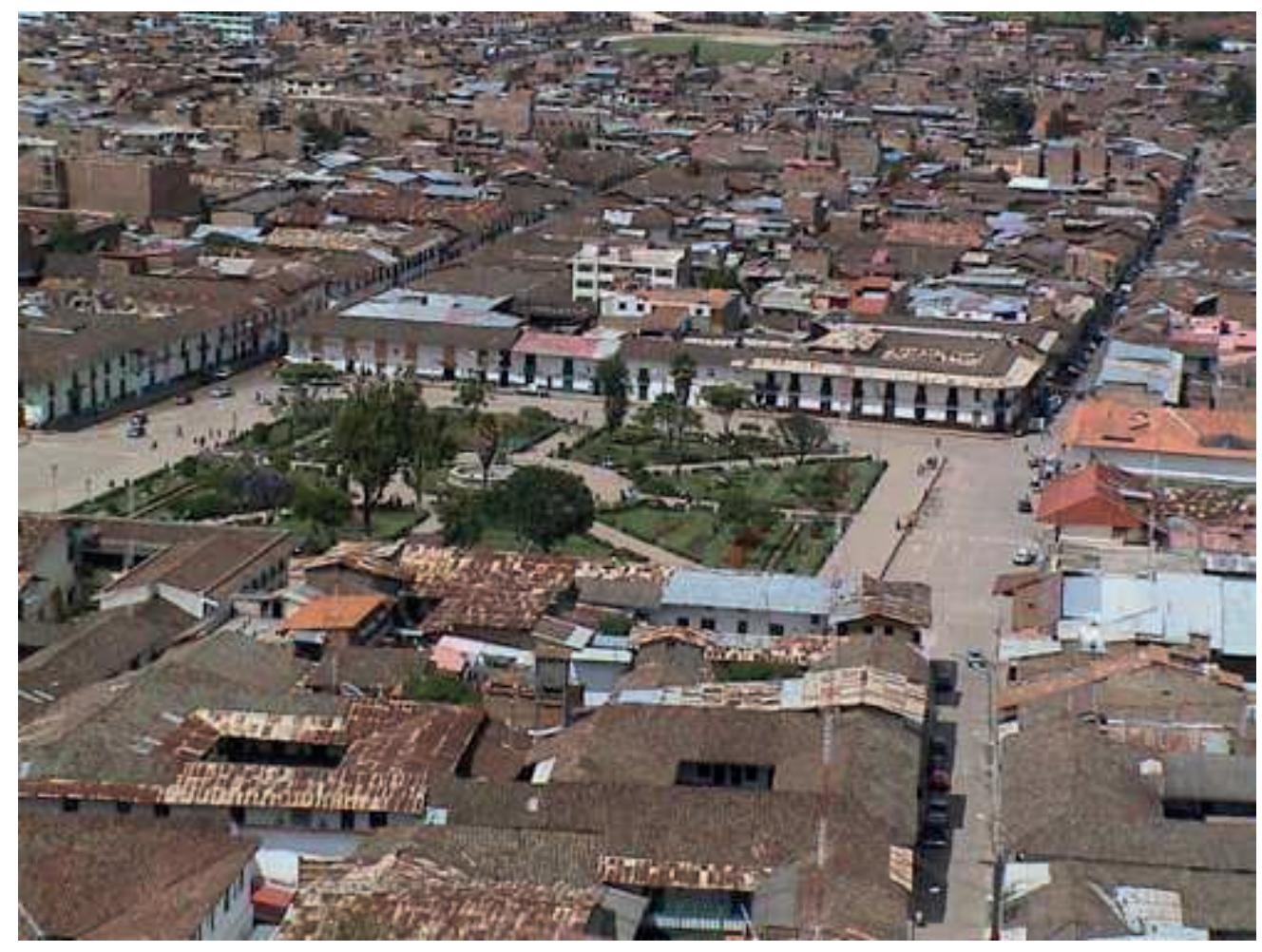

Figura 10. Bucólico panorama de la ciudad de Cajamarca, con la plaza de Armas en primer plano. Foto tomada del sitio Web "Wochenendausflug nach Cajamarca, 27.28.10.2001". 


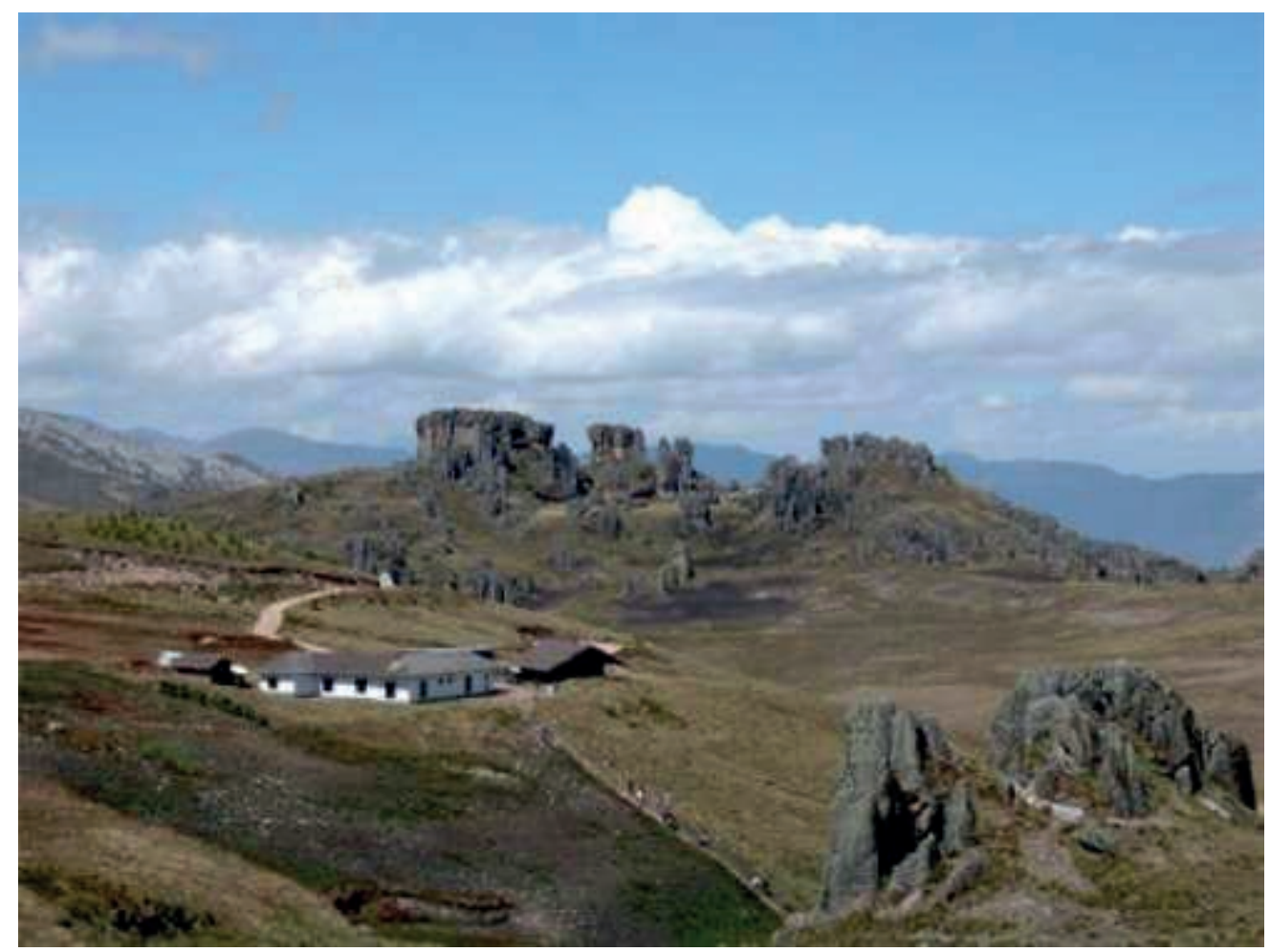

Figura 11. Vista de Cumbemayo (Cajamarca). Foto obtenida del sitio Web trackscout.ch.

Luego de que una empresa privada nos demostrara ser una falla de antología en cuanto a la organización, la prevención y el trato brindado a los visitantes, vimos que estos no estaban "solos". Después le "tocó el turno" a una institución gubernamental tan "linajuda" como es la filial de Cajamarca del Instituto Nacional de Cultura INC (Nota 5), la misma que, supuestamente, tiene la responsabilidad de velar por la preservación de los monumentos arqueológicos y coloniales de esta ciudad. Cuando quisimos acudir a este organismo en busca de información -como dijimos arriba, era el mes de enero, para muchos, temporada baja-, no encontramos a ningún funcionario de esta institución estatal, es más, la caseta que tienen cerca de la Plaza de Armas estaba cerrada a pesar de tener un horario de atención al público colocado en la puerta. Después, nos enteramos que estos señores sólo aparecen en las llamadas temporadas altas, cuando, por ejemplo, se celebran los famosos carnavales cajamarquinos $\mathrm{u}$ otras festividades. $\mathrm{Y}$ como era de esperar, tampoco encontramos 
ningún efectivo de la policía de turismo. Vale decir, tal parece que es por estas épocas, cuando nadie los controla, en que empresarios sin escrúpulos hacen de las suyas, abusan de los turistas, y se llevan toda el agua para su molino. Si esto es así en Cajamarca, ¿cómo será en el resto del país?

Ante esto, resulta chocante constatar que el futuro "Plan Estratégico Turístico Nacional" no contemple, casualmente - ¿o no lo es? - , el aspecto humano de los turistas. Esta "omisión", como vemos más abajo (ver Capítulo 5. Por esta pata "cojea") ha hecho pensar a algunos que también el gobierno del presidente Toledo quiere agarrar del pescuezo a la pobre gallina de los huevos de oro y, como ciertos representantes de la actividad privada dedicada a este rubro, pretende condicionar la industria sin chimeneas a sus propios intereses. Por esto el gobierno peruano se ha sumado al "ninguneo", digámoslo así, desentendiéndose de la parte humana de quienes nos visitan, e ignorando las necesidades y expectativas del visitante. $\mathrm{O}$, si lo hacen, como lo hace el sector turístico privado, siempre estarán tratando de aprovecharse de su poder, de aparentar, de engañar con una publicidad mentirosa de sus ofertas turísticas e, incluso, apropiándose ilegalmente de recursos turísticos que no les pertenecen. La realidad no es ficción. La realidad es lo que le puede pasar a uno si cae, por pura mala suerte, en manos de operadores $u$ agentes turísticos inescrupulosos, y todo ahora con la anuencia de quienes supuestamente deben velar por quienes nos honran con su visita.

\section{Por esta pata "cojea"}

"Organizar, promover y dirigir el desarrollo sostenible y competitivo de la actividad turística del Perú, mediante procesos integradores, concertados y descentralizados, impulsando el desarrollo económico y social, generando empleo digno que mejore la calidad de vida de la población y garantizando la valoración y 
conservación del patrimonio nacional histórico, natural y cultural." De "Misión del PENTUR", preámbulo del "Plan Estratégico Nacional de Turismo 2005 - 2015".

"El nuestro es uno de los 10 países con mayores reservas de recursos naturales del planeta. A pesar de eso, nuestra oferta turística no está considerada entre las más atractivas del mundo. Del total del mercado mundial de turismo, Perú sólo recibe el 0,13 por ciento..." Declaraciones del titular del MINCETUR, Alfredo Ferrero, durante la presentación oficial del PENTUR. ${ }^{27}$

Al margen de sus bondades, que no le faltan, y tras un meditado análisis, hemos encontrado que la "cojera" de este "plancito" comienza, en primer lugar, en el rubro "A" del mismo. Éste trata acerca de la política a adoptar sobre el turismo receptivo, que es el que mayores reparos ofrece para los visitantes nacionales y extranjeros. En su punto "1. Focalización de la promoción turística en los mercados prioritarios y potenciales" señala lo siguiente:

a. Investigar, mediante estudios de mercado y otras técnicas, los mercados turísticos prioritarios y potenciales.

b. Evaluar la demanda potencial en los mercados identificados con relación a la oferta turística peruana.

c. Identificar los segmentos especializados de la demanda potencial de los mercados y establecer la calidad de su relación con la oferta turística Peruana.

d. Monitorear y evaluar los resultados obtenidos y la retroalimentación de los procesos de mercadeo.

27 "Perú, sede de Machu Picchu, se alista para catapultar turismo". Noticia publicada por Terra España. http://www.terra.com/actualidad/articulo/html/act181999.htm 31/8/04 
Según nuestro modesto parecer, aquí faltaría agregar los puntos "e" y "f". Estos deberán tomar en cuenta tanto la relación entre los operadores turísticos y los visitantes, como también el vínculo entre el "negocio turístico" -llámese "inversión privada" en infraestructura y servicios afines- y los pueblos y comunidades en cuyas áreas geográficas se encuentran asentados los recursos turísticos. Suele suceder, y esto lo sabemos por experiencia propia, que la explotación comercial del patrimonio cultural o natural de determinado lugar puede ser objeto de cuestionamientos, reparos, reclamos y quejas entre los pobladores de los lugares donde estos recursos se encuentran. Se trata, entonces, de encontrar una justa interrelación entre la actividad turística y los actores locales involucrados de una $\mathrm{u}$ otra forma por la misma. Los planteamientos que siguen a continuación pretenden ofrecer unas pautas para "taponar" esta gruesa y descalificadora omisión del PENTUR:

e. Investigar, estudiar, identificar, individualizar y evaluar los segmentos de la oferta turística que más reclamos, quejas o reparos genera en los visitantes, de modo que se pueda manejar con más criterio y consecuencia la relación entre los prestadores de servicios turísticos, sin excepción -agencias de viajes, líneas aéreas, transporte interprovincial, hoteles, restaurantes, etc. - , y los turistas, tanto nacionales como extranjeros, para diseñar, establecer y aplicar con rigor un sistema de normas claramente reglamentadas con el objeto de vigilar y cautelar por la seguridad durante la prestación de servicios turísticos, y fiscalizar la atención de las necesidades humanas de los turistas como clientes de estos servicios -como es el caso de la salud, por ejemplo (ver Nota 6) - .

f. Esta política también deberá comprender la relación existente entre el "negocio turístico" -llámese "inversión privada" en infraestructura y servicios afines- y los pueblos y comunidades en cuyas áreas geográficas se encuentran asentados los recursos turísticos, cuya explotación también suele encontrar reparos, reclamos y 
quejas entre los lugareños. Se trata, entonces, de encontrar una justa interrelación entre la actividad turística y los actores locales involucrados de una u otra forma por la misma, con medidas y acciones correctivas que permitan su aplicación.

Esto puede implicar una nueva visión acerca de la problemática de cada segmento de la oferta turística respecto a sus potenciales clientes $\mathrm{y}$, también, respecto a la población de las áreas geográficas donde se desarrolla esta actividad. Con esto se pretende llenar un clamoroso vacío legal y normativo que, a decir verdad, atenta peligrosamente contra el turismo en el Perú, y el crecimiento sostenido que pretende el PENTUR. Con ello proponemos llevar a cabo las siguientes acciones:

1. Aplicar mecanismos de protección y defensa del consumidor para quienes utilizan los servicios turísticos, sean peruanos o extranjeros.

2. Diseñar medidas de control, como ya se indicó, para evitar sigan los reiterados abusos de los que tanto se quejan los turistas. Éstas, asimismo, deberán comprender a las poblaciones de las áreas geográficas donde se encuentran asentados los negocios y/o recursos turísticos.

3. Tipificar estos abusos como delitos o faltas graves, pasibles de sanción penal y con indemnización pecuniaria.

4. Se sancionará drásticamente estas faltas o delitos, tipificados según el código civil, el código penal, la Constitución y las leyes vigentes. (ver Nota 6)

5. Se considerará como delito grave, pasible de sanción penal y con indemnización, al prestador de servicios turísticos que se niegue a atender o responsabilizarse por el bienestar y la salud de sus clientes turistas. Para el efecto, el prestador de servicios turísticos que brinde servicios de tours fuera de núcleos urbanos o en lugares de 
altura, deberá contar, en sus medios de transporte y en la propia empresa que dirige, con los medios o implementos adecuados para primeros auxilios necesarios que permitan enfrentar situaciones de emergencia. Las unidades móviles que llevan turistas a lugares de altura, deberán contar, igualmente, con un balón de oxígeno y un equipo de radio de emergencia. (ver Nota 6)

Aquí tenemos, pues, la pata "coja" de este "plancito" que puede tener muy buenos propósitos, pero que, por lo visto, necesita que sus diseñadotes reciban clases de relaciones humanas -además de relaciones públicas - , y un bastón, si es que no hay una pata biónica o cosa por el estilo. Esto último a juzgar por lo que se puede leer en el capítulo 6: "Quejolandia: la voz del turista es la voz de Dios...", que sigue a continuación. Por más que digan que nuestro turismo "está bien", y esto lo ha dicho el actual titular del MINCETUR, Alfredo Ferrero, la verdad es que nuestra "industria sin chimineas" puede estar mejor. 


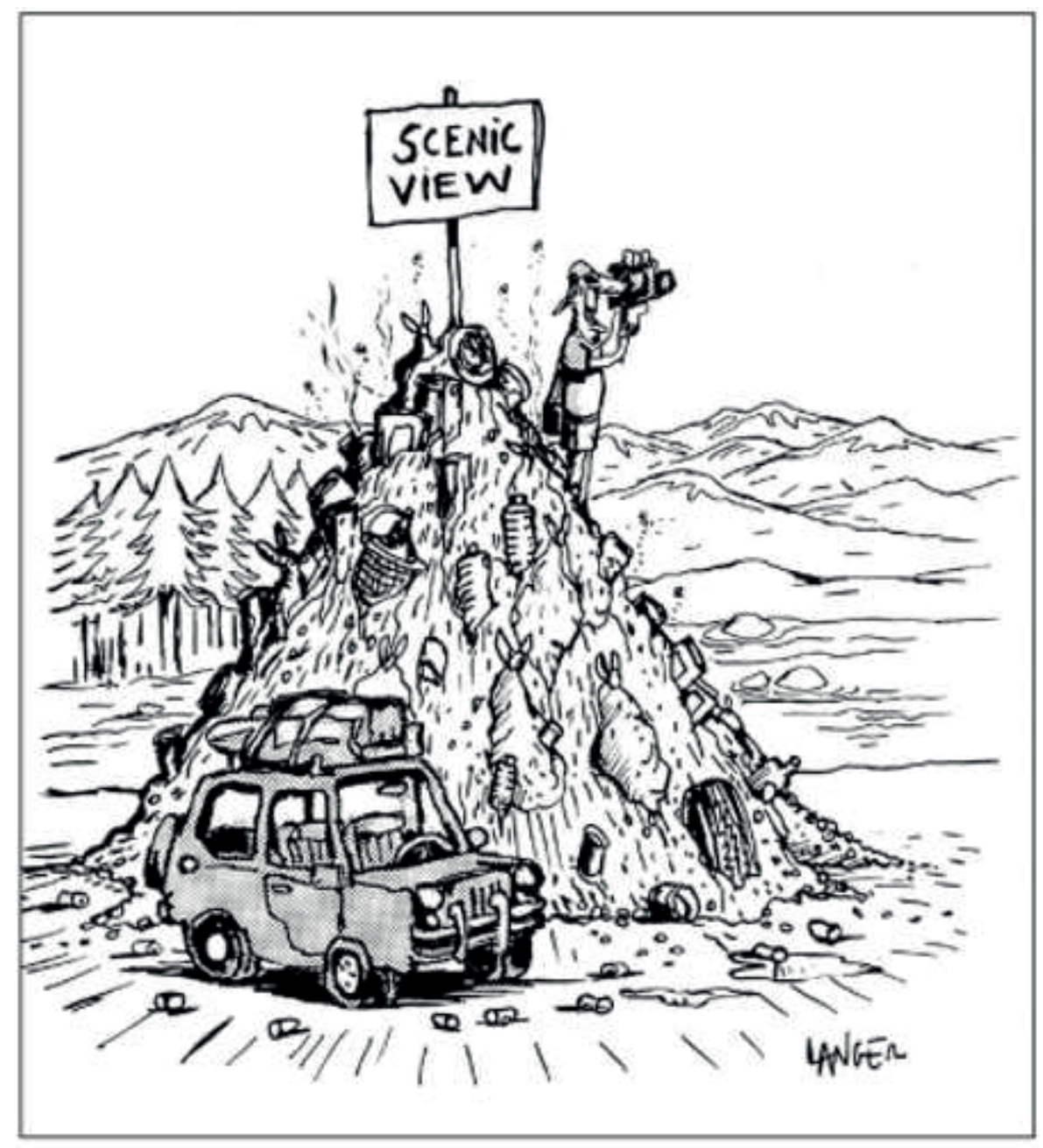

Figura 12. "Scenic View". Las palabras sobran, este es nuestro turismo... ahora iy mañana? Caricatura de Sergio Langer, Argentina. Portal "Turismo Visión".

\section{Quejolandia: la voz del turista es la voz de Dios...}

"(...) Sin duda nuestro "Producto Turístico", como si fuera un todo, tiene su punto más débil en los atributos más tangibles: la limpieza, el funcionamiento correcto de un servicio higiénico, un televisor de hotel que funcione, un guía poco profesional y mal preparado y muchos detalles de este tipo. Aquí las quejas que recoge Indecopi nos pueden ayudar a conocer en detalle lo que piensan los turistas de lo que falla de nuestro producto turístico. Necesitamos aprender a valorar que la calidad del 
servicio turístico, se encuentra en todos los detalles por muy insignificantes que nos pueden parecer."

Edwin Vilchez Medina ${ }^{28}$

\subsection{Mensajes recibidos en el periodo 2001 - 2004}

Nota: Se ha optado por respetar el texto original de estos mensajes, algunos de los cuales, como verá el lector, tienen gruesas faltas de ortografía. Asimismo, se han insertado las referencias de cada caso, tal como aparecen en el portal "Quejas Perú"29

\subsubsection{4}

\section{Categoría: TURISMO}

Nelson Benito Medina,10726302,Pueblo Libre,30/07/2004

tical_net@hotmail.com

Título: CIVA TRANSPORTES, CHOQUE DE BUS, SOBRECARGA DE PESO, Y ATROPELLO DE DERECHOS

Queja: Compre un boleto Nasca - Cusco por el valor de S/. 70 el miércoles 28 de Julio por la mañana a la empresa CIVA. Me dijeron que este en el terinal a las 8.30 pm porque el bus salía a las 9pm. Llegue puntual y espere hasta las 12.15 am hora en que recién me dijeron la verdad tras muchos \"ahorita llega\":el bus de empresa CIVA sobrecargó su límite permitido, quedándose por lo que tuvo que quedarse detenido en la balanza de la carretera cerca del peaje. Tenía que regresar a Chincha para descargar cosas y enrumbarse nuevamente a Nazca, cosa que tomaría más de dos horas Fue por imprudencia de la empresa que mi viaje se vio frustrado cambiando todos mis planes de hacer turismo en Cusco. En ese momento luego de una tediosa

\footnotetext{
${ }^{28}$ Opinión sobre encuesta acerca del turismo en el Perú.

http:/ /listas.rcp.net.pe/pipermail/turismo/2002-May/000056.html 08/9/04

${ }^{29}$ Portal Quejas Perú. http://www.quejasperu.com/ 05/9/04
} 
insistencia por mi parte, el administrador de la agencia accedió a cambiar mi boleto para el día siguiente, mismo asiento (44) y misma hora de salida (9pm). El día 29 de Julio llegue nuevamente al terminal y aborde el bus que partía a Cusco el cual salió a las 9.15pm. Al partir, se detuvo en la siguiente en el Restaurant La Flecha Dorada. Paso alrededor de media hora hasta que se enrumbo por la carretera a Puquio cerca de Cantayo, no obstante se volvió a detener en la ruta para poder abordar pasajeros informales. Yo me encontraba en el asiento 44 al lado del pasillo cerca de la parte trasera del bus. Uno de los pasajeros nuevos se sentó a mi costado en el asiento que estaba vacío. A solo media cuadra de la entrada a los acueductos de Cantalloc, en una curva rodeada por un cerro cortado por la autopista el bus hace una maniobra brusca que altera a la gente. La ventana de mi derecha colisiona contra algo que nunca supe que fue. El vidrio revienta y yo me cubro. El carro frena bruscamente y mi ropa está llena de vidrios y me encuentro manchado de sangre del pasajero del lado. Por suerte salgo ileso, pero el pasajero del lado estuvo herido. Conversando con el chofer, me indico propuestas como \"te damos el asiento16 \" o \"más adelante te ponemos en otro bus \".Yo vivía en la hacienda Cantayo, justo cerca de donde se estrello el carro por lo que decido no viajar. La ventana estaba rota, los asientos llenos de vidrios y finalmente el chofer me dice que decide regresar al terminal de partida. Para ahorrarme todos esos trámites innecesarios, volví al lugar de donde salí; la Hacienda Cantayo a solo unas cuadras del accidente. Cuando llame a la agencia, ellos no estaban ni enterados de lo ocurrido./"Alguien\" por teléfono me aseguro que al día siguiente podrían a acceder a devolverme mi dinero. Al día siguiente la recepcionista me dijo que había sido informada de que: NO HUBO HERIDOS, EL CARRO NO REGRESO A LA AGENCIA EL CHOFER HABRIA LLEVADO EL CARRO A REPARAR EN EL CAMINO Y DE ALLI HABRIAN SEGUIDO SU RUTA NORMAL A CUSCO. Por supuesto, como el accidentado era alguien que recién había subido en el camino y seguramente no estaría registrado. Como usuario agraviado la mínima actitud decente por parte de la empresa seria devolverme de inmediato el valor de mi pasaje. Perdí muchas cosas, amigos que me esperaban en 
Cusco, reservas, y el tour al Camino Inca. Pero lo más importante: mis ganas de viajar. La agencia de Nasca espera que un nuevo pasaje compense eso. Esperaban que viajara con la ropa llena de vidrios rotos y sangre. Esperaban que tuviera un viaje placentero y que el asunto se olvidara con solo llegar a Cusco. Creerían que de todos los viajes que voy a hacer en Perú, alguna vez me atrevería a subir de nuevo a un bus Civa. Una empresa con tal actitud solo refleja una gran incompetencia y un nulo respeto por el servicio al cliente. Al parecer no existe preocupación por dar una buena imagen, y por lo menos yo no tengo confianza en dicha compañía. Cuando no hay trabajadores que sepan resolver problemas y se tiran la pelota uno a otro solo muestran el pobre reflejo de una empresa incapaz de atender adecuadamente a los turistas. Si alguien lee este artículo, solo debería ponerse en mi lugar y pensarlo dos veces antes de comprar un boleto en Civa.

\author{
Categoría: TURISMO \\ Rodrigo, San Isidro, 07/05/2004 \\ ro_acevedos@hotmail.com
}

Título: OLTURSA DE ARAMBURU ES UNA JAULA DE CHOLITAS AGUANTADAS

Queja: Una amiga y yo nos fuimos a oltursa a comprar unos pasajes y las $\backslash$ "mujeres \" que atendían, estaban más preocupadas en mirar a un tipo que entro, alto, delgado que se nota que viajaba constantemente por trabajo... un poco más y se quitan los ojos entre ella, así que no fui idiota y empecé a jilear con ella , a pesar de que no me gustaban para nada... cuando el chico este se retiro, ellas decían que querían que él sea el padre de sus hijos y que era un cuero, bla bla bla... solo me quede pensando y entendí porque siempre dicen que las peruanas son unas cholas aguantadas.

El chico tenía enamorada, pero la hizo linda... 
Categoría: TURISMO

Alberto, Lima, 05/05/2004

Título: OLTURSA ES UN ASCO

Queja: Es el colmo, en oltursa de Ian Isidro todas las que atienden paran más preocupadas en jilear y en coquetear con los clientes que atender... por favor hagan su trabajo y se ve muy mal que los hombres la choteen y solo las escuchen para ser atendidos más rápido. Estaba haciendo mi cola y llego un muchacho a comprar un pasaje... por poco y entre ellas se sacan los ojos, el sonriente hizo que lo atendieran mucho más rápido y las cajeras no dejaban de piropear... el se retiro y llamo a su novia, enamorada o esposa diciendo... amor de mi vida ya tengo los pasajes... mientras ellas copiaban el mail del muchacho

\section{Categoría: TURISMO}

Nombre: Jorge Aguirre Abrill, 00481329, San Borja,02/01/04

Jaguirre@southernperu.com.pe

Título: EL COLMO DE LA CORRUPCION DEL PTE. GOBIERNO, GRACIAS A NOSOTROS

Queja: En el mes de junio 2002 por este mismo medio presente mi queja por la inacción de la Autoridad Autónoma del Colca -ente burocrático que jamás debió existir, ya que su única misión era la de cobrar US\$2.00 por cada Turista que visita el Cañón del Colca sin que éstos beneficien siquiera con una mejora en la catastrófica carretera que une Chivay con los demás pueblitos de dicho valle-. Pero parece que las luminarias que tenemos en el gobierno han leído mal mi queja porque en lugar de quitar el cobro de los indicados US\$2.00 y desaparecer dicha entidad burocrática que no aporta nada para atraer al Turismo, ahora han subido a US\$ 6.00 la tasa por visitar nuestro Patrimonio Turístico, o sea $200 \%$ de incremento. Es una pena que este Gobierno que ofreció tanto desaparecer este tipo de instituciones improductivas, ahora le dé la espalda al pueblo que lo ayudo a llegar al poder. 


\subsubsection{3}

\section{Categoría: TURISMO}

Carolina Asalde, 10762208 12/12/03

Título: BILLETES FALSOS PARA LOS TURISTAS!!

Queja: La presente es para alertar a los turistas extranjeros o que visitan el Perú.... el penúltimo sábado de noviembre dos amigas peruanas y un amigo de suiza estuvimos en el bar la Noche de barranco, pagó la cuenta nuestro amigo con un billete de S/.100, recibió su vuelto, por coincidencia esa noche no lo ayude a chequear el billete, el día martes siguiente en un restaurante descubrimos que el billete de s/.50.00 era FALSOOO! solo pudimos hablar con el gerente del bar el sábado siguiente, quien prácticamente insinuó que mentíamos... ES UNA PENA QUE SE APROVECHEN DE LOS TURISTAS DE ESTA MANERA, LAMENTABLEMENTE CON ACTOS COMO ESTOS NO SE DEJA MAL A UN BAR SI NO A TOOODO EL PERU!

\section{Categoría: TURISMO}

Lizeth huamanlazo vila, 41945717, Av. proceres de la independencia, San Juan de Lurigancho 03/10/03

sazethj@yahoo.com

Título: TRATO DENIGRANTE AL PERUANO

queja: En mi viaje al Cuzco no pude creer el trato tan denigrante que se da al peruano solo por el simple hecho de serlo, mi retorno que esta vez lo hice de Aguas calientes hasta ollantaytambo decidí comprar un pasaje de costo local y me di con la sorpresa que el baño de ese bagón uno observa la vía férrea, además el olor a pestilencia que era tan insoportetable, mas aun observar a las personas viajar durante 2 horas paradas algunas con bebes, no pude creer que sucedía esas cosas hablando de una compañía que tiene prestigio y más aun ser la única vía férrea en el CUZCO. 
Ayúdenme a que esta situación cambie ya por el bien de las personas que viven allá y nosotros mismo los peruanos.

\subsubsection{2}

\section{Categoría: TURISMO / MIGRACIONES}

Nombre: Gonzalo Medina Sánchez, 29597301, Karlsruhe, Alemania, 19/09/2002

Email: gmedina@web.de

\section{Título: ROBO EN EL AEROPUERTO JORGE CHAVEZ}

Queja: Quiero denunciar por este medio el sistemático robo del que vienen siendo objeto los turistas extranjeros que visitan nuestro país al momento de abandonar el Aeropuerto Jorge Chávez: El personal de control de pasaportes les dice a los turistas extranjeros, por lo general turistas que viajan solos, que el color del sello (rosado, por ejemplo) estampado al momento de ingresar al Perú corresponde a un mes de estadía en el Perú (siguiendo con el ejemplo) y que para el tiempo de estadía (tres meses) le corresponde otro color (de), por lo cual tienen que abonar la suma de 80 dólares por "multa" antes de tomar el avión. Si el turista duda o reclama, le presionan diciendo que si no paga va a ser borrado de la lista de pasajeros y perderá el vuelo. Obviamente el turista presionado accede a pagar y si no tiene la cantidad correspondiente, el agente le dice que abra (!) su billetera y le de lo que tenga. La amiga alemana que me contó esto le tuvo que dar 5 euros, 15 dólares, 20 soles y 10 leks (moneda albanesa). Además le preguntaron si no tenía sencillo. Advirtamos a nuestros amigos extranjeros acerca de esta robo cuando viajen a Perú para la acción de unos miserables no borre la linda imagen que los turistas se llevan de nuestro país.

\section{Categoría: TURISMO}

Nombre: Jorge Aguirre A., 00481329, San Borja Lima, 07/06/2002

Email: Jaguirre@southernperu.com.pe 


\section{Título: CARRETERA AL CAÑON DEL COLCA}

Queja: Según lo manifiestan las autoridades del Gobierno, están empeñados a superar cada vez más la cantidad de Turistas que visitan el Perú. Lamentablemente estas buenas intenciones se ven empañadas por el escaso o nulo interés de las instituciones como AUTOCOLCA (Autoridad autónoma del Colca) que la única labor que cumple en el sector Turismo es de ente recaudador (US\$ 2.00 por cada Turista) sin que ese dinero revierta siquiera en arreglar la desastrosa carretera que lleva desde Chivay hasta la Cruz del Condor. Aparentemente eso ni les interesa ya que existen tramos sumamente peligrosos (Ejem. Maca) a los que no les prestan la más mínima atención pese a que ya se han sucedido algunos accidentes. Me pregunto, a donde irán a parar todos los montos recaudados, porque se supone que son para mejorar todos los aspectos de atractivo Turístico de la zona. Esperemos que pronto se cree el Ministerio de Turismo, para que así desaparezcan esas instituciones burocráticas que no justifican para nada su actual existencia.

\section{Categoría: TURISMO}

Nombre: Marco Alvarez, U.S.A., Florida, 01/06/2002

Email: vcosser@juno.com

Título: QUE PODEMOS HACER?????

Queja: hace 30 anos que salí del Perú y en 2002 todavía existe el mismo problema. Al salir del aeropuerto vía-Lima la pobreza y inmundicia que existe en la Av.Faucett. Esas familias necesitan del gobierno para desarrollarse y vivir sanamente y a la vez darle al turismo una buena impresión, porque es lastimoso que personas ajenas a nuestro país reclamen lastima y así se ahuyenten sin dejarnos esa divisas que necesitamos. Ayudemos al Perú y a esos pobres indigentes que no tienen futuro. Recuerden que el turismo trae MILLONES DE DOLARES Gracias Marco Álvarez 
Categoría: TURISMO

Nombre: PINILLOS GARCIA \& ASOCIADOS SAC, 07538584, MAGDALENA DEL MAR, 21/05/2002

Email: 19960948@ALOE.ULIMA.EDU.PE

Título: HOTEL SOL DE ORO DE CINCO ESTRELLAS ¿?-UNA DESGRACIA queja: BUENAS ME DIRIJO A TODOS AQUELLOS PROVEEDORES QUE ESTAN PENSANDO EN PROVEERLE AL HOTEL SOL DE ORO DE MIRAFLORES CUALQUIER PRODUCTO LES ACONSEJO QUE NO LO HAGAN YA QUE CORREN EL RIESGO DE QUE NO LE PAGAN NI A TIEMPO NI NUNCA . A MI ME DEBEN ALREDEDOR DE 2500 SOLES Y YA VAN 6 MESES Y NO LA VEO. NI LO PIENSEN SIQUIERA. GRACIAS

\section{Categoría: TURISMO}

Nombre: P Barbis Gardella, 25677083, La Punta - Lima, 17/05/2002

Email: pbg44@cesaro.com.pe

\section{Título: PROMOCIÓN DE PROYECTO TURÍSTICO ERRADO}

Queja: En el colmo de la desvergüenza y en ausencia del más ligero asomo de concordancia con nuestra realidad histórica y patrimonial - cultural, escuchamos en las últimas semanas como un grupo de representantes del gobierno apoyan, promocionan y apuran de manera extrañamente diligente un proyecto de inversión en las playas del norte de nuestro país, proyecto millonario que demostrará una vez más que los intereses particulares priman sobre la lógica y la realidad. Señores, nuestro país ha sido, es y seguirá siendo un importantísimo centro turístico con una particularidad que lo hace único, su riqueza cultural, Perú no compite con destinos culturales similares en todo el continente, excepto México y Guatemala, pero difiere también de ellos en que en nuestro territorio la cultura existe intacta y se puede vivenciar, nuestra riqueza se vive en las ferias comunales, en las calles de los pueblos de la sierra, en los mercadillos de Ayacucho y Puno, entre muchos otros, soy Piurano, Peruanazo pero luego de muchos años trabajando en turismo soy consciente 
que lo que debemos impulsar es lo que realmente nos hace no diferentes solamente, sino UNICOS, nuestro ancestro Inca, nuestras ruinas y ciudades, Chachapoyas, Cuzco, Puno la hermosa Ayacucho, la exuberante Amazonía......pero playas ???? algún turista despistado vendrá a pagar hotelazo de 5 estrellas para bañarse en "Playa Hermosa" señores, Perú no compite como circuito mundial de turismo con playas, para eso está el Caribe por una fracción de distancia y precio que el que podrán ofertar por este absurdo proyecto, propiciado por cuatro señores que definitivamente piensan en beneficios propios por sobre la razón, la lógica y la coherencia cultural que representamos a los ojos del turismo y los turistas mundiales. Acaban de lanzar "PERÚ" como marca. Lindo logo made in Germany, con ruinas y aves exóticas más, hermosa musicalización andina, lo nuestro, lo real, lo único, en el video de promoción, nuestra comida de variedad y sabores interminables, nuestras ruinas, nuestra gente, historia viva, no recreada y pregunto entonces.....qué queremos vender al mundo turístico....playas ??? De no creerlo. PBG

\section{Categoría: TURISMO}

Nombre: VANESSA LUKAC, 10805538, MIRAFLORES, 05/02/2002

\section{Email:VLUKAC@YAHOO.COM}

Título: TAXIS ABUSAN DEL TURISTA

Queja: Señores "a quien corresponda": yo viajo 1 vez a la semana dentro del Perú por trabajo y es el colmo que a cada ciudad que llego tenga que "negociar" con los taxistas ladrones que se paran afuera para tratar de conseguir una carrerita. Bueno llevo 3 meses en esta lucha. Ejemplo llego a Piura y llevarme de Apto a una oficina a 10 minutos a lo mucho me quieren cobrar 12 solsasos. La tarifa debería de ser 4 soles y si le pido factura hasta 6, imagínense como es posible que pretendan estafar a la gente con el doble del precio justo. No creen que debería de haber una empresa de taxis en los aptos siempre disponible con tarifas razonables, que den boleta o factura pero con tarifas ya establecidas por distancias??? Creo que la gente pagaría unos 
soles más por un buen servicio como ese, pero el doble nunca!!! Esa sería una forme de motivar el turismo y generar trabajo.

\section{Categoría: TURISMO}

Nombre: Luis, 22313846, lima, 02/02/2002

Email: luchomar@mixmail.com

Título: RESERVA NACIONAL DE PARACAS INGRESO DEMASIADO CARO

Queja: soy un pisqueño el cual deseaba visitar la reserva de paracas pero me encontré con la sorpresa de que la entrada estaba 5 soles para visitar las playas dentro de la reserva yo no soy un turista para pagar esa suma todavía las pistas dentro de la reserva son malas no se que hacen con el dinero de las entradas??

\section{Categoría: TURISMO}

Nombre: Raul Zevallos, 07882521, Miraflores, 05/01/2002

Email: rzevallosd@terra.com.pe

Título: MALTRATO A TURISTAS

Queja: Unos familiares americanos que por primera vez visitaban el país decidieron regresar del cusco vía terrestre (Ormeño) y en el camino querían que se levanten de sus asientos por haberse vendido pasajes en exceso ellos eran 2 adultos y tres niños, incluso el trato en el counter de lima fue de lo mas malcriado al haberla atendido a la Sra. Curtis una Srta. que estaba pendiente de atender a un señor que le solicitaba dinero en la parte interna y riéndose con los otros dos muchachos que la acompañaban. Así quien querrá usar nuestros servicios? los turistas generan ingresos pero hay que saber tratar a la gente nos debemos a ellos en muchos casos.

\subsubsection{1}

\section{Categoría: TURISMO}

Nombre: Juan Carmona, DIN 78990000, Bogota, 16/11/2001 
Email: carmona@aol.com

Título: ROBOS EN LIMA

Queja: Autoridades peruanas por favor reducir el número de ladrones en Perú. Muy difícil visitar Lima.

\section{Categoría: TURISMO}

Nombre: Henrry Chávez Dios, 06408559, Tumbes, 07/11/2001

Email: turismomundial@terra.com.pe

Título: ESTAFA A TURISTAS

Queja: Nuestra queja va en el sentido que a todo turista que entra al Perú por esta cuidad de Tumbes, llega por Huaquillas -Ecuador, y es en esta zona donde los cambistas Ecuatorianos timan al turista al darle soles falsos o dándoles menos dinero con sus calculadoras arregladas.

Acudimos a ustedes para que den una voz de alerta a los consulados y embajadas, para que recomienden a sus conciudadanos a que no realicen ninguna transacción con moneda peruana en el lado Ecuatoriano, porque son muchas las personas que han sido engañadas. Gracias

\section{Categoría: TURISMO / HOTELES}

Nombre: César Anza, 09387163, Chorrillos, 29/10/2001

Email: cesara@volred.com.pe

Título: HOSTIGAMIENTO DE LA CADENA DE HOTELES EL LAGO AREQUIPA

Queja: Cuando regrese de viaje en el Aeropuerto Jorge Chávez me hicieron una encuesta acerca de mis preferencias turísticas me dijeron que entraría en un sorteo de unas vacaciones pagadas en algún lugar del Caribe (Bahamas) creo, al poco tiempo me llamaron a los teléfonos que di para invitarme a una charla con mi esposa para conocer acerca de la cadena de Hoteles el lago, me habrán llamado unas 20 veces hasta que asistí siendo requisito ser poseedor de una tarjeta de crédito, la exposición no fue del todo clara era sobre sistemas de vacaciones compartidas en un lugar lleno 
de mesitas con música estridente para que no escuches lo que hablaba el resto de posibles incautos compartidas fue hecha por un chico peruano de buen trato pero presionaban de tal forma a adquirir dicho plan solo ese día con una oferta especial(para eso era la tarjeta) al nuestra negativa llamo a su jefe un joven de chileno que en tono malcriado y prepotente nos dijo que "Así son los Peruanos no creen ni en su país" y nos dijo "no hemos dicho nada" se paro molesto pues le manifieste que había asistido a presentaciones similares en EE.UU y que no creía en ellas ni tenia los elementos de juicio para cerrar el trato ese día, así que tengan cuidado con las encuestas que llenan y más aún si dan sus números de telefono.

\section{Categoría: TURISMO}

Nombre: Lewins Leiva Ariza, 10699708, Santa Anita, 11/10/2001

Email: lewleiva@hotmail.com

\section{Título: MALOS SERVICIOS TURISTICOS}

Queja: Mi queja es por los paquetes turísticos de Huaraz, en especial a: "turismo LALO", resulta que tome un paquete a Chavin y debido a la gran cantidad de turistas, nos juntaron a todos los turistas, incluyendo a gente de otras empresas en un bus grande y viejo, que se malogro en medio del viaje y resulta que el dueño del bus es solo contratado que ni siquiera estaba de acuerdo con salir pues sabía de la condición del bus. En conclusión, quisieron aprovechar de la cantidad de turistas sin tener los buses adecuados, es decir aceptaron a todos excediendo su capacidad.

\section{Un "turismo" (de) rico(s) que está matando al turismo en un país de pobres (y un artículo que lapida la incongruencia)}

"Sería oportuno preguntarse cuál es el destino de todo ese dinero, tomando en cuenta que los niveles de pobreza en Cuzco son mucho más clamorosos que en departamentos menos turísticos. Por ejemplo, la esperanza de vida de un cuzqueño 
está entre las más bajas de Perú (60 años). ¿Cómo se administran los ingresos de Macchu Picchu o los impuestos que pagan hoteles, restaurantes y agencias de viajes?" Wilfredo Ardito Vega. ${ }^{30}$

Antes de proseguir con el revelador artículo que mostraremos a continuación, conviene aquí hacer una reflexión de lo andado. Por lo que se puede apreciar, es indudable que la actividad turística "oficial" -la promovida por el gobierno peruanoy la de los operadores y prestadores de servicios turísticos, y la de los "ricos", es la que realmente está matando por inanición al turismo en el Perú. Unos, "con más cara que un buey con paperas", como diría jocosamente Julio Gutiérrez, director de esta revista, se han tomado atribuciones de "príncipes azules" y han pretendido "exclusivizar" esta actividad económica. Y encima quieren hacer creer a medio mundo que son ellos los capos del turismo, los "expertos" que dicen saberlo todo, pero, a la hora de la verdad, no dan pie en bola. Otros, por su lado, insisten en quedarse en su nube rosada, verde o azulada, sin darse cuenta de que se pueden caer al menor despiste, y allí están, encerrados en su presunción, los dueños de aquellos grandes negocios del turismo que se mueve a costa del esfuerzo de otros. Y entre estos últimos están quienes han diseñado el ya famoso "plancito", sin el menor tapujo para continuar con la misma novela, sin el menor atisbo de un saludable cambio, como en lo que se refiere a la parte humana de esta actividad y su relación con la parte humana de los turistas. Y esto, obviando la responsabilidad social que deberían tener los "peces gordos" del turismo nacional. Ellos mismos dicen, hipócritamente, que la responsabilidad social "debería aplicarse". Pero ésta les resbala como baba por sus cuentas bancarias y tarjetas de crédito doradas. Y mientras tanto, las autoridades del sector turismo, con Alfredo Ferrero a la cabeza, siguen "echándole flores" a un PENTUR que hasta ahora no saben si nació cadáver.

30 "Cusco: Esplendor y miseria". http:// www.adital.org.br/site/noticia.asp?cod=9929\&lang=ES 10/9/04 
"Plancito", pues, y de marras, que si lo leyera un cusqueño, seguro, lo tomaría como una bofetada a su dignidad humana. Este buen hombre, mientras sueña con salir de la pobreza, se topa con los operadores turísticos y se ilusiona, como "personaje típico" que es. Se viste con esos trajes multicolores y los operadores turísticos lo utilizan para tomarse fotos con visitantes extranjeros, que lo miran inconscientes de su tragedia. Pero cuando se da cuenta que todo es a cambio de migajas, entonces, seguramente pensará que él va a seguir siendo pobre, en tanto que los otros, esos "cuantos", los que explotan la industria del turismo, sí que se aprovechan -de él y de su ingenuidad - y se llevan sus ganancias al bolsillo y se ríen en su cara. Y para su desgracia, siempre lo van a tratar con desprecio y sólo lo llamarán para utilizarlo como algo "tipical" y nada más, una situación a la que nadie parece interesar que cambie.

\subsection{Cuzco: esplendor y miseria. Artículo de Wilfredo Ardito Vega (*)}

La parte humana, es, pues, el descalabro del turismo en el Perú. Y con mayor razón si tomamos en cuenta la cruel paradoja que significa observar un turismo "rico" en medio de la miseria. Los operadores turísticos se dedican a traer visitantes que viven en la abundancia y en sus recorridos por el Perú reciben todo lo que a los otros, a la mayoría, les falta. $Y$ todo esto sucede mientras a su lado hay niños que no tienen para comer, y, para colmo, se encuentran con unos operadores turísticos que a veces se aprovechan de esa miseria-. Para Wilfredo Ardito Vega, abogado e investigador de la realidad social peruana, conocido en nuestro medio por liderar una valiente cruzada a favor el respeto a los derechos humanos y contra la discriminación racial, no hay la menor duda. Él piensa que antes de acometer cualquier reforma o acción de cambio en el sector turístico, conviene resolver la crucial coyuntura que significa el factor humano de la pobreza en el Perú y su relación con esta actividad económica. 
Mirar con otros ojos al turista, y al entorno en que se desenvuelve la actividad turística, implica, entonces, un cambio de actitud radical frente a los verdaderos actores y protagonistas del mundo del turismo, vale decir: los turistas y la gente. Pues los turistas son gente que viaja, y lo que van a ver no son necesariamente ruinas o árboles -aunque esto forma parte de la escenografía, y también atrae, como Machu Picchu-, sino de la gente del lugar donde se encuentra la atracción turística que visitan. Y la gente por su lado, son personas que viven en los lugares adonde van los turistas, y son su mejor recepción. Son, en todo caso, gente que va a ver gente, para conocerlos a ellos y lo que hicieron sus antepasados. (Nota 8)

Adital - Perú $\left(^{* *}\right)$ - "Es de noche y una niña canta valses con lastimera voz, para luego pedir limosna. Estamos en una pizzería de la calle Procuradores, a pocos metros de la Plaza de Armas del Cuzco. La niña sale bajo la lluvia a continuar su recorrido en otros restaurantes, escoltada por un individuo con cara de pocos amigos.

En otras ciudades, ningún restaurante aceptaría participar en esa forma patética de explotación, sea por razones morales o por simple buen gusto.

Sin embargo, el turismo a veces logra revelar lo mejor y lo peor de una sociedad. Es innegable que genera riqueza..., pero en los lugares donde existen notables diferencias económicas, más bien puede terminar profundizándolas.

Los elevados costos harían pensar que Cuzco es una región opulenta: en el Valle Sagrado una noche de hotel supera los 100 dólares; el ingreso al nuevo Museo de Arte Precolombino está a 25 soles; llegar a Macchu Picchu desde Aguas Calientes, incluyendo el obligatorio viaje en micro, cuesta 29 dólares a un extranjero y 19 a un peruano. Si calculamos que Machu Picchu recibe más de 200.000 visitantes al año, la mayoría extranjeros, comprenderemos que se trata de millones de dólares. 
Sería oportuno preguntarse cuál es el destino de todo ese dinero, tomando en cuenta que los niveles de pobreza en Cuzco son mucho más clamorosos que en departamentos menos turísticos. Por ejemplo, la esperanza de vida de un cuzqueño está entre las más bajas de Perú (60 años). ¿Cómo se administran los ingresos de Macchu Picchu o los impuestos que pagan hoteles, restaurantes y agencias de viajes? Este es un auténtico enigma, pero en todo caso, dicho dinero está muy mal distribuido: mientras para el próximo año se ha previsto, como prioridad, la construcción de palcos de lujo en el Estadio Garcilaso, sólo Huancavelica tiene una mortalidad infantil más elevada.

La miseria hace que muchos campesinos busquen obtener dinero inclusive violando la ley o atentando contra su salud. En las últimas elecciones municipales, varios candidatos a la Alcaldía de Macchu Picchu pagaron a muchas personas para que se inscribieran como habitantes del distrito y así obtener sus votos. De manera aún más chocante, un investigador médico revela que, a raíz de la ayuda alimentaria que el Ministerio de Salud otorga a las mujeres embarazadas, se ha incrementado el número de madres de cuarenta o cincuenta años.

La coexistencia de turismo y necesidad aparece graficada dramáticamente en el famoso Camino Inca, que tantos visitantes extranjeros anhelan conocer. Lo que muchas veces se ignora es que la expedición implica llevar por tres o cuatro días un séquito de campesinos encorvados bajo el peso del equipaje, balones de gas, carpas y cocinas. La Ley 27607 estableció un salario mínimo y otras condiciones de trabajo, pero muchas veces no se cumple. Los cargadores carecen de comida, calzado o vestimenta adecuados, con frecuencia se les prohíbe hablar a los turistas y, naturalmente, los infelices ni siquiera entran a las ruinas (aunque para los cuzqueños es gratis). Muchas veces, el brutal esfuerzo físico les generará lesiones en la columna vertebral para el resto de su vida. Y es imposible que sea de otra forma, porque al 
Camino Inca no se puede ingresar solo, sino contratando a una agencia de viaje, que a su vez reclutará a los cargadores.

Una autoridad estatal sensible y seria podría lograr que los campesinos reciban un trato digno, pero precisamente, la ausencia de aquélla es una constante para el visitante. Para quienes no hacen el Camino Inca, el viaje a Macchu Picchu también puede generar un duro choque con la realidad. Los trenes de Perú Rail cuestan a los extranjeros 60, 90 y 360 dólares, pero existen trenes para peruanos a 30 soles. Mientras los primeros se quejan de la discriminación, el tren para peruanos que retorna de Macchu Picchu suele ser una experiencia de hacinamiento, donde muchos pasajeros deben viajar de pie o sentados en los pasillos (teniendo su boleto en la mano). Recientemente, la única forma que los pasajeros tuvieron para respirar fue rompiendo las ventanillas y el tren llegó al Cuzco pasada la 1 de la mañana (tres horas y media después de la hora indicada). "No podemos hacer nada, porque es una empresa privada", decían los policías ante los reclamos de los pasajeros.

Más allá de la falta de escrúpulos de una empresa o una agencia de turismo, la principal causa de este panorama es el desinterés del Estado para asumir sus responsabilidades, desde garantizar un eficiente manejo de los ingresos que se reciben, hasta evitar la explotación de niños y adultos, pasando por promover un transporte público en condiciones decorosas, para todos, peruanos y extranjeros.

La debilidad estatal termina afectando inclusive el patrimonio histórico, como ocurrió hace unos años con el Intihuatana, el reloj solar de Machu Picchu. Varios hoteles han derribado o modificado valiosos muros incaicos, sin mayor autorización. En San Blas, se suceden las construcciones sin licencia, alterando la fisonomía monumental del barrio, mientras la Municipalidad y el INC parecen atados de manos, por acciones de amparo o por los insuficientes mecanismos de control. 
¿Cómo empezar a retirar este panorama? Se trata básicamente de asumir con seriedad lo que significa el gobierno local y regional, considerando como prioritaria la situación de los más vulnerables, aquellos que son menospreciados desde su nacimiento, sea por vivir en el campo, por no hablar castellano, por ser discapacitados.

Hasta para el turista más distraído, es evidente el brutal contraste entre un majestuoso pasado y un vergonzoso presente. Si no se rompe la indiferencia frente a todo este sufrimiento, tarde o temprano la región se expone a mayores estallidos sociales (como los recientes ataques al tren para extranjeros) o a un incremento de la delincuencia. A diferencia de los demás departamentos pobres, Cuzco cuenta con muchos recursos que, bien administrados, podrían generar una vida mejor para todos sus habitantes. ${ }^{31}$

$\left(^{*}\right)$ Responsable del Proyecto Nacional de Jueces de Paz del Instituto de Defensa Legal y profesor de Sociología del Derecho de la Universidad Católica.

(**) Artículo publicado el 19/11/2003

\section{9. ¿Sabía Usted que...?}

... el portal "Turismo Visión", una Web dedicada al ecoturismo, denunció en diciembre de 2001 la subrepticia "privatización" de la fortaleza preincaica de Kuelap (Amazonas), uno de los monumentos más emblemáticos del antiguo Perú. Según refiere la noticia, éste habría sido hecho por oscuros personajes allegados al régimen del presidente Alejandro Toledo, utilizando una extraña resolución suprema, uno de

\footnotetext{
${ }^{31}$ Op. Cit. http://www.adital.org.br/site/noticia.asp?cod=9929\&lang=ES 07/9/04
} 
cuyos artículos, como dice el denunciante, viola los derechos de las comunidades nativas vecinas a este enclave? (Ver "Perú: ¿Kuelap Privatizado?") 32

...el sitio Web de "Información y Asistencia al turista" de PromPerú, como el PENTUR, también adolece de serias deficiencias, como es la de no mencionar nada acerca de cómo enfrentar emergencias durante, por ejemplo, un tour contratado en el interior del país: no hay información sobre primeros auxilios ni cómo llamar a una ambulancia; tan solo recalca que: "Es muy importante precisar qué información y asistencia al turista. No recomienda agencias de viaje, establecimientos de hospedaje, restaurantes o servicios de transporte y tampoco hace reservaciones, trámites migratorios o aduaneros." $\mathrm{Y}$, aunque en su base de datos hay una referencia sobre hospitales y centros de salud, no señala que la unidad móvil del tour que uno contrate debería tener, por ejemplo, un botiquín o un balón de oxígeno?33

...hace poco se denunció que, debido a la sobreexplotación comercial de unos cuantos lugares turísticos en el Perú -Cusco, Machu Picchu, Nasca, Arequipa, Ayacucho, Iquitos...-, se están dejando de lado unos 15 mil destinos turísticos tanto o más importantes?

... los lineamentos de la "Declaración de Lima", firmado por los representantes turísticos de los países latinoamericanos en la ciudad de Lima el 7 de febrero del $2002^{34}$, contienen propósitos y requerimientos para el desarrollo responsable, con justicia y equidad del sector turismo -en especial del ecoturismo-, que en el Perú aún no se cumplen?

32 "Perú: ¿Kuelap Privatizado?"

http://www.tourism-watch.de/esp/5esp/5esp.peru/index.html 07/9/04

${ }^{33}$ Sitio Web de Información y asistencia al turista de PromPerú.

http://www.promperu.gob.pe/s_ftoiperu.asp 06/9/04

34 "Declaración de Lima".

http://www.tourism-watch.de/esp/5esp/5esp.lima/index.html 10/9/04 
...en el texto de la mencionada "Declaración de Lima" no hay nada alusivo a la preocupación que deberían tener los operadores turísticos por la salud de sus clientes cuando estos contratan sus servicios?

..."las cifras de "Llegadas de Visitantes Extranjeros al Aeropuerto Internacional Jorge Chávez" continúan con el buen desempeño mostrado desde inicios del 2004. Mes por mes superan los registros del año pasado y es probable que el año cierre con una cifra record. El mes de julio presenta un notorio incremento, donde, si bien mantiene la tendencia que ya se estaba dando, no podemos dejar de mencionar que en dicho mes se registró también el arribo de turistas extranjeros para asistir a un evento que se volvió a realizar en Perú después de varias décadas, como es la Copa América de fútbol?35

...en enero-julio 2004 arribaron 437.802 visitantes extranjeros al Jorge Chávez, lo que significó un incremento del 19\% respecto a los 367.630 visitantes extranjeros arribados en enero-julio 2003"? 36

...En una entrevista que se le hizo al notable especialista en turismo, Julio Ascensión Ugarte, este manifestó que "... el desarrollo del turismo peruano en la actualidad es depredador, el fruto más caro es Machu Picchu, debido a que el gobierno no ha cumplido ninguno de los compromisos adquiridos hace dos años. Al Perú se le conoce más por Machu Picchu que por el país mismo, sin embargo, hasta hoy no existe un plan de desarrollo para esta zona. No se tienen ni siquiera los límites catástrales de las ruinas y lo que es más grave hay una yuxtaposición de casi cinco

\footnotetext{
35 Inform@ción.com "Arribo de visitantes extranjeros al Aeropuerto Internacional Jorge Chávez 2002 - 2004". http://www.informaccion.com/turismo/noticiasturismo.html 10/9/04

${ }^{36}$ Idem 35.
} 
instituciones que quieren controlarlo, eso lo hace caótico. Bajo ese escenario no creo que el país pueda mejorar sus ingresos."?37

...hay recursos turísticos que no están preparados para el flujo de turistas que el PENTUR pretende traer al Perú, ni siquiera Machu Picchu. Sin embargo, hay "sabihondos" en la materia que dicen que esta célebre ciudadela puede recibir (¿?) 3.000 turistas diarios, cuando los especialistas han recomendado entre 300 a $400 \ldots$ y eso que actualmente llegan unos mil visitantes por día a esta zona. Parece que han confundido al país con las playas España o el Caribe. Con razón, pues, los recelos de la UNESCO, verdad?

\section{Conclusiones}

Como ya vimos, el propósito de esta trabajo ha sido hacer valorar la parte humana y las necesidades de los turistas ante los servicios de los operadores y agencias turísticas, y también la relación existente entre el supuesto "auge turístico" en el Perú y la realidad social, donde el turismo receptivo sólo parece beneficiar a unos pocos. Pues, como ya se ha visto: de no mediar una voluntad política de cambio, por más que se diga que esta actividad puede sacar de la pobreza a miles de peruanos, éstas, hasta ahora, sólo son frustrantes palabras.

La problemática del turismo en el Perú no resiste un estudio superficial de su coyuntura. Hay que plantearse la necesidad de valorar y reivindicar la parte humana del turista y el accionar de esta actividad frente a la sociedad alrededor de la cual se desenvuelve. La coexistencia de un "turismo rico" entre "gente pobre" es un anacronismo irreconciliable. Tienen que darse, pues, los mecanismos que ayuden al cambio. Este es el objetivo del PENTUR, pero es evidente que le ha faltado lo más

37 "Turismo peruano es depredador" Entrevista a Julio Félix Ascensión Ugarte publicada por el portal "Generación". Perú. http:/ / www.generaccion.com/entrevistas/entrevista1.asp?identrevista=39 14/9/04 
importante como ya señalamos. Por ello, presentamos las siguientes conclusiones, fruto de este trabajo:

1. En nuestro país el turismo se desenvuelve en un ambiente exclusivista y alienante, plagado de injusticias, desigualdades y dándole la espalda a las carencias de cientos de miles de peruanos.

2. ¿Qué es más insultante? ¿Un turismo de ricos o la explotación de la pobreza para enriquecer a un grupúsculo de empresarios turísticos ricos?

3. En el Perú no hay la "economía con rostro humano" que prometieron los políticos que ahora nos gobiernan; es más, aquí la actividad turística tampoco tiene rostro humano.

4. El turismo en el Perú es sinónimo de capitalismo salvaje y una brutal falta de sensibilidad humana; el sistema imperante no ha sido diseñado para la solidaridad, ni menos la preocupación por los demás -de los turistas y de la sociedad alrededor de la cual se desenvuelve esta actividad-. No se salva del "salvajismo" de la "inversión privada" el entorno medioambiental -que incluye la flora y la fauna de cada ecosistema o región- donde se desarrolla el "negocio turístico".

5. En coincidencia con el punto anterior, en su voracidad, el turismo receptivo que manejan los operadores turísticos en el Perú, depreda, extrae, consume, empobrece... y no da nada -o casi nada- a cambio.

6. El turismo en el Perú es una prueba más de que la riqueza en este país, y bajo las circunstancias actuales, no se reparte con equidad, menos aún, lo está en el "plan" del PENTUR, donde no hay una sola alusión a la responsabilidad social tanto del sector público como del privado. 
7. El turismo, menos aún el PENTUR, no contribuirá a sacar de la miseria a nuestros pueblos, mientras gobiernos, autoridades políticas y civiles, ni los propios empresarios y operadores turísticos, no tomen conciencia sobre lo que esto significa, por lo que deberán cambiar su óptica respecto a esta actividad económica y asumir su responsabilidad social. Y esto debe comenzar con la parte humana esta actividad. Con cuánta razón se ha dicho que "hay que explotar al turismo, no al turista".

8. Como en otras actividades económicas estratégicas, en el sector turístico peruano hay una explotación del ser humano por el ser humano, todo ello agravado por la indiferencia, el desprecio por la condición humana, la insolidaridad, la falta de compasión por el sufrimiento ajeno, y el egoísmo perverso de quienes se enriquecen con el esfuerzo de otros. El PENTUR no puede estar ajeno a esta coyuntura si se quiere lograr algo positivo.

9. Hay operadores turísticos que, con la anuencia y la complicidad encubierta de gobiernos y políticos corruptos, a través de una sarta de "leguleyadas" (Nota 7), pretenden apropiarse, mediante "concesiones" fraudulentas de los recursos turísticos en el interior del país. Según reiteradas denuncias -que han encontrado un sospechoso silencio-, existen casos en que lugares turísticos han sido entregados a terceros, para que los administren y usufructúen, aportando poco o nada al desarrollo de los pueblos y comunidades donde estos se encuentran. Esto a pesar de los ingentes ingresos que obtienen por concepto de turismo receptivo.

10. Un sistema legal obsoleto y anacrónico -diseñado por legisladores que no saben donde tienen la cabeza - conspira contra el desarrollo de la actividad turística hacia los niveles de eficiencia, competitividad, justicia, equidad y responsabilidad social. 
11. Los prejuicios sociales, las barreras económicas, la discriminación de todo tipo, el racismo, la intolerancia y la insolidaridad son todavía taras no superadas. -OJO, señores del PENTUR - : incluso dentro de la actividad turística, todavía hay casos de gente rechazada por ser de color, como se ha podido constatar en algunas discotecas y restaurantes de elite, en varios puntos del país, sobre todo en Cusco y Lima, donde se margina a quienes no sean "gringos" -que sean o parezcan extranjeros - o "blancos".

12. En el PENTUR no hay una sola alusión a la explotación del turismo, pero si lo hay del turista, vale decir, aún no entienden que el turista es un ser humano, no, como ya dijimos, una billetera abierta. Es más, una persona con dignidad y necesidades. ¡No piensan en eso!

13. En lo que respecta a los servicios que brinda PromPerú, no hay una sola referencia a las medidas a tomar ante emergencias que pongan en riesgo la salud y la vida de los turistas durante un tour contratado a un servidor turístico.

14. En la legislación peruana actual sobre esta actividad económica, no hay un solo artículo que estipule la exigencia u obligatoriedad de los operadores turísticos de responsabilizarse no solo por la seguridad sino también por la salud de los turistas mientras estos contratan sus servicios.

15. Asimismo, en las normativas vigentes no hay una sola mención a la exigencia de dotar a las unidades móviles -sobre todo las utilizadas en los servicios turísticos por el interior del país y zonas de altura-, de los implementos necesarios para emergencias, tales como un botiquín, un balón de oxígeno, un extintor...

16. Las normas legales vigentes, impulsadas por el neolibaralismo de la corrupta gestión del ex presidente Alberto Fujimori -cuya derogatoria todavía está en agenda 
para el actual gobierno del presidente Alejandro Toledo-, tampoco le hacen ningún favor al turismo receptivo, pues afectan a su régimen laboral. Esta situación configura una serie de condiciones injustas para quienes laboran en esta actividad. Son reglas de juego que otorgan prioridades a los empresarios, pues permiten la explotación del hombre por el hombre y dan "carta blanca" para que se cometan impunemente los peores abusos y violaciones contra los derechos de los trabajadores turísticos.

\section{Para saber más}

(Nota: A la derecha de los hipervínculos se ha insertado la fecha de última apertura de la página Web citada)

Ministerio de Comercio Exterior y Turismo del Perú.

http:/ / www.mincetur.gob.pe 03/9/04

PROMPERÚ.

http:/ / www.promperu.gob.pe/peru.asp 07/9/04

Revista Caretas "¿El Año de los 600.000 turistas?" Revelador informe publicado durante la época fujimorista. Edición del 20 de Junio, 1996 - Nº 1419 (Como se verá, la situación poco ha cambiado)

http:/ / www.caretas.com.pe/1419/cusco/cusco.htm 07/9/04

Revista Caretas "A todo tren".

http:/ / www.caretas.com.pe/2003/1791/articulos/bingham.html 06/9/04

Revista Caretas. "Filma y fuga".

http:/ / www.caretas.com.pe/2000/1629/articulos/turismo.phtml 07/9/04 
II Congreso Internacional de Turismo Cultural NAyA Octubre del 2003

http://www.naya.org.ar/turismo/politicas_para_el_turismo_1.htm 07/9/04

Cusco, Patrimonio Cultural de la Humanidad.

http://www.unsaac.edu.pe/cusco/index.shtml 07/9/04

El Diario del Cusco.

http://www.diariodelcusco.com/ 07/9/04

Machu Picchu, Patrimonio Cultural y Natural de la Humanidad: problemas y alternativas.

http://www.aeet.org/ecosistemas/022/opinion2.htm 07/9/04

Machu Picchu: Guide Inka Trail.

http://www.machupicchu.biz/ 05/9/04

Guía Turística de Machu Picchu.

http://www.go2peru.com/spa/machu_picchu_travel_guide.htm 03/9/04

Portal Peruano de Defensa del Consumidor.

http://www.aspec.org.pe/ 06/9/04

Indecopi.

http://www.indecopi.gob.pe/\# 06/9/04

"Siguen abusos de malos taxistas del aeropuerto contra los turistas".

http:/ / www.larepublica.com.pe/noticia_cs.jsp?pIdNoticia=13754\&pId=7 07/9/04

Percepción del servicio turístico en el Cusco Documento PDF. 07/9/04 
"Machu Pichu". Artículo sobre la polémica de la sobreexplotación turística de las ruinas de Machu Picchu, publicado por el portal "Ciberpsique". http:/ / www.ciberpsique.net/printarticle971.html 07/9/04

\section{ADITAL}

http://www.adital.org.br/ 07/9/04

\section{Notas}

(1) Toda vez que ya se han levantado voces de protesta por la excesiva sobreexplotación de este recurso turístico. Y esto no es todo. Lo mismo viene sucediendo con las Líneas de Nasca, donde, tras la muerte de la recordada estudiosa germano-peruana María Reiche (1903-1998), este invalorable tesoro del desierto está siendo objeto de la depredación. Hay dibujos que han sido literalmente "atropellados" por culpa de conductores irresponsables. Peor aún, operadores turísticos sin escrúpulos, con la complicidad de autoridades corruptas, malos políticos y peores representantes del Poder Judicial, se han "apropiado" literalmente de este famoso yacimiento arqueológico. Ésa es, pues, "la inversión privada", que en lugar de invertir, más bien parece estar "invertida"... que vive de lo que no le pertenece y no da nada a cambio; o si lo hace, sólo da demagogia y se llena los bolsillos a costa de esfuerzos ajenos.

(2) Los visitantes extranjeros no tienen nada de tontos. Cuando se dan cuenta del trato que dan los prestadores de servicios turísticos, ya sea directa o indirectamente, sencillamente se dan media vuelta, y se van para otra parte, o no vuelven más, dando esto una mala y justificada imagen de los servicios turísticos peruanos, "esquilmadores" de billeteras foráneas. Cuando fui a Italia, nunca encontré a una legión de chicas tratando de venderme una Inca Kola, bebida gaseosa muy popular en el Perú; nadie me molestó en Chile cuando hice con mis padres un tour por 
Santiago; ni mucho menos encontré una agencia de viajes abusiva y ladrona, pero si muy servicial y eficiente, cuando estuve en Buenos Aires. Una realidad que debería ser como la nuestra. ¿Por qué en el Perú tiene que suceder lo contrario? Hay que aprender de países como Ecuador. Por paradójico que parezca, este pequeño país, en el año 2003, logró una cifra récord en cuanto a turismo receptivo. ¿El secreto? Se han dado cuenta que el turista es una persona que viene a disfrutar de las bellezas de ese país, y que el visitante, sin que lo presionen, consumirá los productos de este país y hará uso de los servicios que ofrecen. Con inteligencia, más que con recursos, gracias a una acertada política turística ${ }^{38}$ y sin llegar a los extremos a que hemos llegado. Han utilizado lo que no emplean muchos de nuestros empresarios turísticos: la inteligencia. Otra cosa es si se viaja por negocios. Y a estos también los está "atrapando" Ecuador.

(3) Un caso que ilustra lo dicho es la secuela de los desastres naturales ocurridos el pasado mes de abril de 2004 en el poblado turístico de Aguas Calientes, perteneciente al distrito de Machu Picchu Pueblo, como el lector podrá constatar en el capítulo 15 (ver 15. Recortes de Prensa II). La ocurrencia del fenómeno ya descrito en este reportaje, en un lugar muy próximo a la célebre ciudadela inca, puso en pie a la UNESCO.

(4) Dos años antes del desastre natural de Aguas Calientes (26), la revista limeña Caretas denunció el caos y el descontrol de este poblado turístico, lugar obligado de paso para quienes van o vienen de Machu Pichu. (ver 14. Recortes de Prensa I 14.1. "Machu Chicha") 39

\footnotetext{
${ }^{38}$ Ecuador - Ministerio de Turismo. http://www.vivecuador.com/html2/esp/ecuador.htm 17/9/04

${ }^{39}$ Revista Caretas "Machu Chicha".

http://www.caretas.com.pe/2002/1742/articulos/machupicchu.phtml
} 
(5) Recomendamos al lector leer esta interesante monografía de Jorge Álvarez von Maack, titulada con una frase suya: "El valor y caos actual del patrimonio cultural del Perú exige urgente cambio de rumbo y mandos...", la misma que habla con postura crítica sobre esta polémica institución a quienes muchos acusan de estar destruyendo la cultura y el patrimonio peruano, en lugar de protegerlo. http://www.monografias.com/trabajos14/rumbomandos/rumbomandos 14/9/04.

(6) Si bien existen mecanismos que, por ejemplo, sancionan a las empresas turísticas por casos como la pérdida de equipajes o el mal trato en algunos hospedajes, estos aún adolecen de serias deficiencias, como, por ejemplo, lo que venimos diciendo: no se exige preocuparse por la salud de los visitantes, sobre todo cuanto estos participan de un tour fuera de zonas urbanas, por lo que se sugiere replantear este punto, que echan en falta muchos turistas extranjeros, acostumbrados a que los servicios turísticos incluyan este concepto: su parte humana y sus necesidades. Algunos hoteles del Cusco, es verdad, suelen brindar a los turistas que recién llegan a la ciudad una taza de mate de coca - para paliar el mal de altura - y los mandan a descansar antes de iniciar los paseos de rigor. Pero en otras muchas localidades del interior del país, nadie se preocupa por ello, es más, existe una total carencia de medios para enfrentar emergencias, como es el caso ya reseñado, que durante un tour a un sitio de altura alguien tenga una crisis respiratoria, ya sea por la altura del lugar o por otra causa. No basta, pues, hacer estudios de mercado, si previamente no se ha considerado también la parte humana y las necesidades de los visitantes. Para establecer la obligatoriedad de los prestadores de servicios turísticos de prestar atención a las necesidades de sus clientes, se deben adecuar las normas legales vigentes. Paso este, fundamental, para que las autoridades competentes hagan cumplir los derechos de los turistas, a que se respete su integridad, tanto física, como material y moral, mientras permanecen en territorio peruano y han contratado un servicio turístico. 
(7) Se entiende por "leguleyada" una burda manipulación "bajo el escritorio" -como se diría - de una ley, decreto, resolución o de una parte de los mismos, o, peor aún, la "invención" de una norma legal con fines que no están dentro de los alcances del estado de derecho, es decir: al margen de la ley. Ésta es una modalidad muy utilizada por los políticos corruptos, sobre todo quienes están en el poder. Baste como ejemplo el artículo "Perú: ¿Kuelap Privatizado?"40, que denuncia un verdadero "atropello legalizado", a través de la "Resolución Suprema N 536-2001-EF", mediante la cual se entrega la fortaleza de Kuelap, ubicada en la región Amazonas (nororiente del Perú), como "concesión" a favor de terceros y sin el debido procedimiento, tal como se puede observar en el mencionado artículo. Lo cierto es que, desde hace un tiempo a esta parte, personas allegadas al régimen del presidente Alejandro Toledo, bajo la fachada de organismos descentralizados, son muy cuestionadas por los reiterados actos de corrupción cometidos por varios funcionarios, como en el caso reseñado de PROINVERSION -antes COPRI - ${ }^{41}$. Hay la sospecha de que estos personajes vienen realizando oscuros manejos con el objeto de apropiarse y lucrarse en su propio beneficio con recursos turísticos que no les pertenecen, bajo el trillado argumento de promover la inversión privada en el sector turístico. En el caso de Kuelap, esta "concesión" en realidad sería una usurpación de un bien cultural a un pueblo, tal como refiere el artículo: “... en la práctica esto significaría el despojo de la propiedad privada de los campesinos del Anexo de Kuelap y comunidades vecinas; además, la exclusividad para el inversionista en el uso, manejo y beneficio del flujo turístico que genere el Complejo Arqueológico de Kuelap, patrimonio de todos los peruanos." Nos preguntamos: ¿si esto fue así con Kuelap, qué no será con otros complejos arqueológicos importantes del Perú? (Ver también: "Carta a Eliane Karp"42).

\footnotetext{
40 "Perú: ¿Kuelap Privatizado?" http://www.tourism-watch.de/esp/5esp/5esp.peru/index.html 07/9/04

${ }^{41}$ PROINVERSION (antes COPRI) http://www.proinversion.gob.pe/default.asp 24/9/04

42 "Carta a Eliane Karp". http:// www.tourism-watch.de/esp/5esp/5esp.carta/content.html 24/9/04
} 


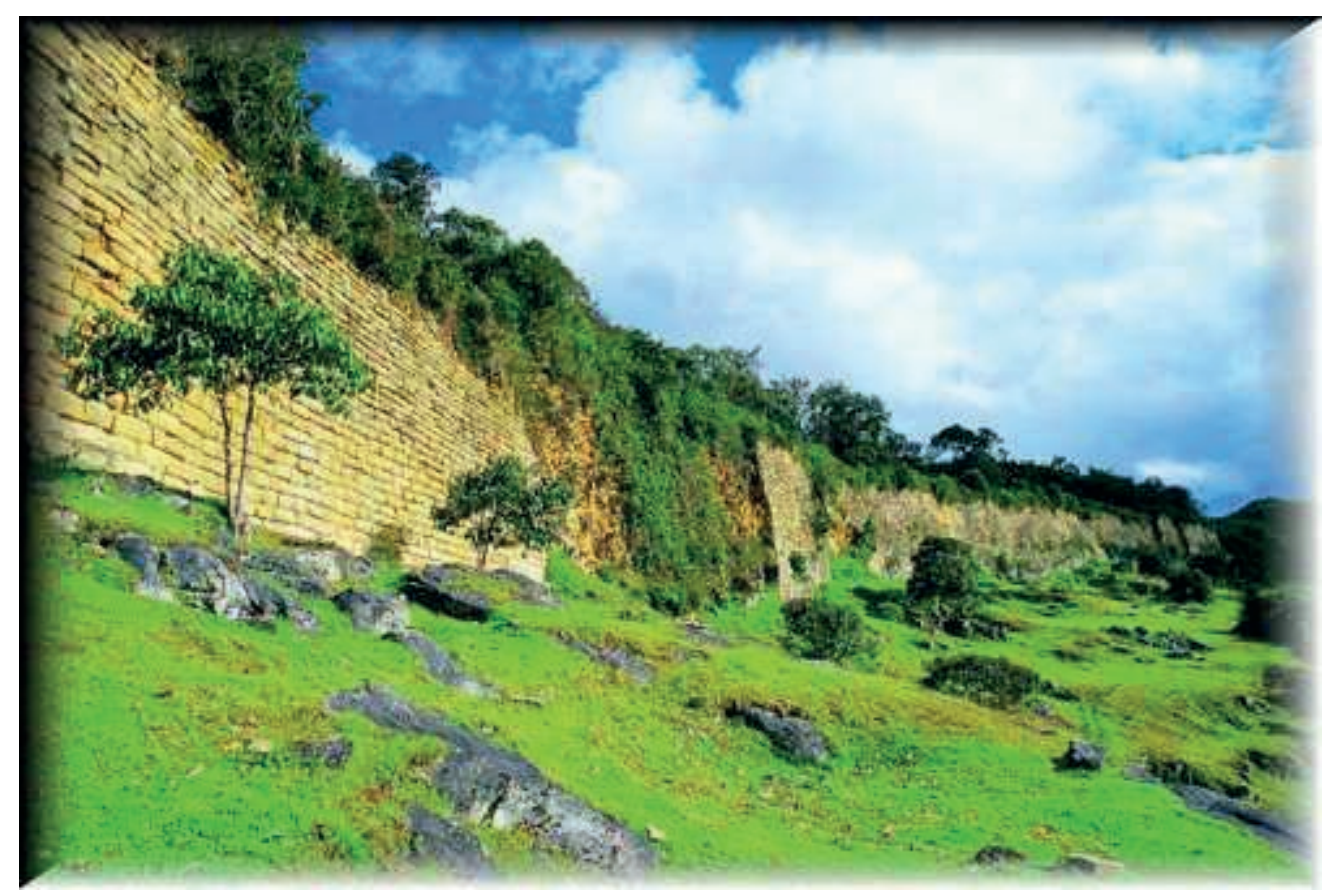

Figura 13. Fortaleza de Kuelap. Foto de Mylene d’ Auriol. PromPerú.

(8) Según el "Diccionario de la Real Academia Española", la voz "turista" es una palabra que viene del inglés "tourist", que significa "persona que hace turismo", y "turismo" viene del vocablo anglosajón "tourism", que en nuestra lengua significa: "1. Actividad o hecho de viajar por placer; 2. Conjunto de los medios conducentes a facilitar estos viajes; 3. Conjunto de personas que realiza este tipo de viajes."

\section{Procedencia de las imágenes}

(Nota: A la derecha de los hipervínculos se ha insertado la fecha de última apertura de la página Web citada)

1. Revista Caretas. 07/9/04

http:/ / www.caretas.com.pe/1419/cusco/cusco.htm 11/9/04

2. Mapa del Perú con las zonas geográficas identificadas por el PENTUR 13/9/04 
http:/ / www.mincetur.gob.pe 03/9/04

3. "Assim caminha a humanidade ao sul do Equador" http:/ / www.tourism-watch.de/esp/5esp/5esp.dollar/index.html 05/9/04

4a. Logotipo del restaurante "Tunupa"

http:/ / paginasamarillas.com.pe/ Anuncios/anuncio.asp?app=be\&n=1281466\&a=205 $82713 / 9 / 04$

4b. Plano de la zona de ubicación del "Tunupa".

http:/ / paginasamarillas.com.pe/Anuncios/anuncio_ubicacion.asp?a=205827\&n=12 $8146613 / 9 / 04$

5. Ficha Técnica del turismo en el Perú. (Cuadro estadístico)

6. Machu Picchu. Foto de Lisandro Távera.

http:/ / www.arqueologia.com.ar/peru/machupic.htm 13/9/04

7. La Estación de Aguas Calientes (Machu Picchu)

http://www.lugaresdomundo.com/machupichu_0304_ing.htm 13/9/04

8. Autovagón para los turistas que viajan a Machu Picchu.

http:/ / www.csufresno.edu/perutour/peru02b.htm 13/9/04

9a. Hoteles 5 estrellas por ciudad, año 2001

http://www.mincetur.gob.pe/default.asp?pag=TURISMO/cuerpo1.htm\&lat=TURI

SMO/lateral.asp?pag=turismo\&num $=4$ 13/9/04

9b. Hoteles 4 estrellas por ciudad, año 2001 
http://www.mincetur.gob.pe/default.asp?pag=TURISMO/cuerpo1.htm\&lat=TURI SMO/lateral.asp?pag=turismo\&num $=4$ 13/9/04

9c. Hoteles 3 estrellas por ciudad, año 2001

http://www.mincetur.gob.pe/default.asp?pag=TURISMO/cuerpo1.htm\&lat=TURI SMO/lateral.asp?pag=turismo\&num $=4$ 13/9/04

9d. Hoteles no clasificados por ciudad, año 2001

http://www.mincetur.gob.pe/default.asp?pag=TURISMO/cuerpo1.htm\&lat=TURI SMO/lateral.asp?pag=turismo\&num $=4$ 13/9/04

10. Bucólico panorama de la ciudad de Cajamarca, con la plaza de Armas en primer plano. Foto tomada del sitio Web "Wochenendausflug nach Cajamarca, 27.28.10.2001"

http:/ / spiegl.de/radiomaranon/ fotos/Ausfluege.und.Umgebung/2001-1026.Chiclayo.und.Cajamarca/Cajamarca/ 13/9/04

11. Vista de Cumbemayo (Cajamarca)

http:/ / www.trackscout.ch/thetrip/ sueda/05-07-03.html 13/9/04

12. "Scenic View".

http:/ / www.tourism-watch.de/esp/5esp/5esp.scenic/index.html 13/9/04

13. Kuelap. Foto de Mylene d' Auriol. PromPerú.

http:/ / www.conperuhouston.org/html/KUELAP\%20FORTRESS\%202.htm 14/9/04

14. Un grupo de mujeres contempla los destrozos provocados por los "huaicos" de Aguas Calientes (Machu Pichu).

http:/ / www.losandes.com.ar/2004/0412/sociedad/nota181822_1.htm 14/9/04 


\section{Recortes de Prensa I}

La difícil e impredecible coyuntura política peruana se presta a sucesos como éste, que retrata la prestigiosa revista limeña Caretas, en un artículo que, aunque un poco pasado, grafica una situación actual.

\section{1. "Machu Chicha"}

Revista Caretas. Edición 1742. Lima, 10 de octubre de 2002

Artículo de Alberto Sánchez Aizcorbe

Aguas Calientes, paso obligado para acceder a la mayor atracción turística del país, las ruinas de Machu Picchu, es vitrina de suciedad, caos y pugna electoral. 


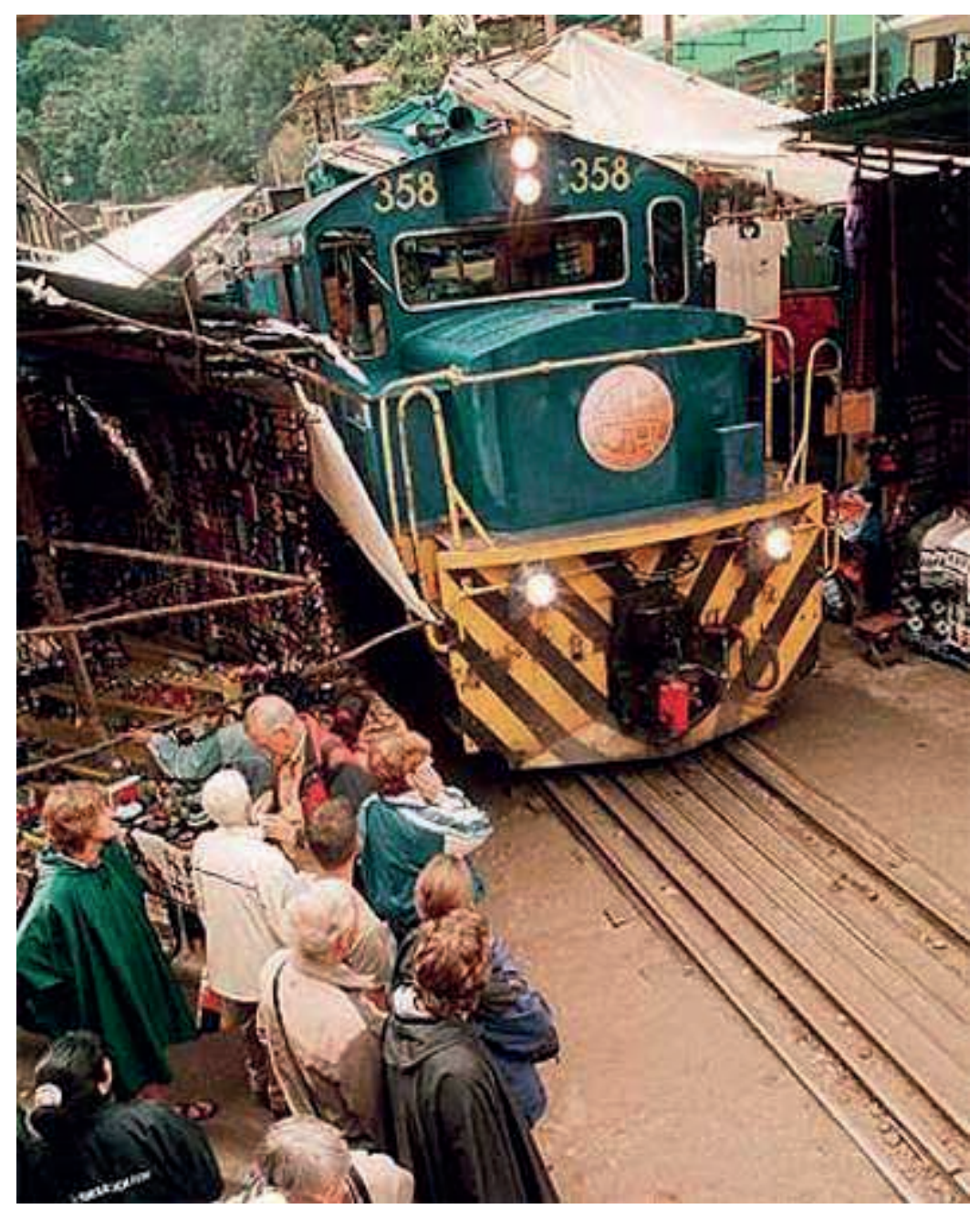

A 2 k.m.p.h. el tren avanza rozando la mercadería que se vende a la derecha de la vía. La autoridad bien gracias.

La bocina del tren suena insistentemente. La campana también. El maquinista comienza a ingresar a la estación de Aguas Calientes con los pelos de punta. Al menor descuido puede llevarse por delante a un turista o a un comerciante que imprudentemente ha colocado una tienda precaria para ofrecer su mercadería al primero; pero que lo hace a pocos centímetros del paso de la locomotora. En términos taurinos se podría decir, temerariamente en terrenos del toro. Lo grave es que este "toro" pesa 100 toneladas y necesita de varios metros para frenar. Varios perros que han perdido una pata lo atestiguan. 
La estación que espera al turista es agradable. Inaugurada a fines de los 90 por el cuestionado presidente Alberto Fujimori, es amplia, cómoda y de sobria arquitectura. Pero no más salir de ella se deben atravesar senderos de tierra encajonados por puestos abigarrados de artesanía y techados con plástico. Estado que se mantendrá a lo largo del recorrido por las callejuelas de Aguas Calientes hasta llegar a abordar una combi para ascender a las famosas ruinas.

Hanan es la palabra quechua que designa la parte alta, hurin la parte baja. Es la mítica dualidad andina, el ying y yang inca. La ciudadela de Machu Picchu puede ser considerada con orgullo la parte alta, hanan. Pero lo que es la parte baja, el poblado de Aguas Calientes, no merece la designación de hurin sino de orín, por la suciedad; por las emanaciones que se desprenden de la basura acumulada en cada esquina; y por el espectáculo en general de caos que presenta la puerta de entrada al santuario arqueológico más visitado del país. Puerta que deben atravesar 1,000 turistas cada día.

Como Simón y Amanda Harvey que, llegados desde Inglaterra, risueñamente se dejaron fotografiar a orillas del río, pese al fondo de basura que se apreciaba a sus espaldas y que aún no había sido llevada por la corriente.

En los últimos años los residuos sólidos, entre 4 y 5 toneladas diarias, eran transportados por Perú Rail gratuitamente y dispuestos en sitio alejado. Pero en las últimas semanas no hay quien se ponga de acuerdo con los gastos de traslado; porque Perú Rail, operadora del ferrocarril Sur Oriente, considera que no es justo correr con el pago de seis dólares kilómetro vagón que el Estado le cobra por dicho traslado; y, al parecer, el Instituto Nacional de Cultura (INC) y el Instituto Nacional de Recursos Naturales (INRENA), que son las entidades que manejan los ingresos del Santuario de Machu Picchu, sólo estarían dispuestas a apoquinar el $40 \%$ de los costos. Del municipio, no se sabe. 


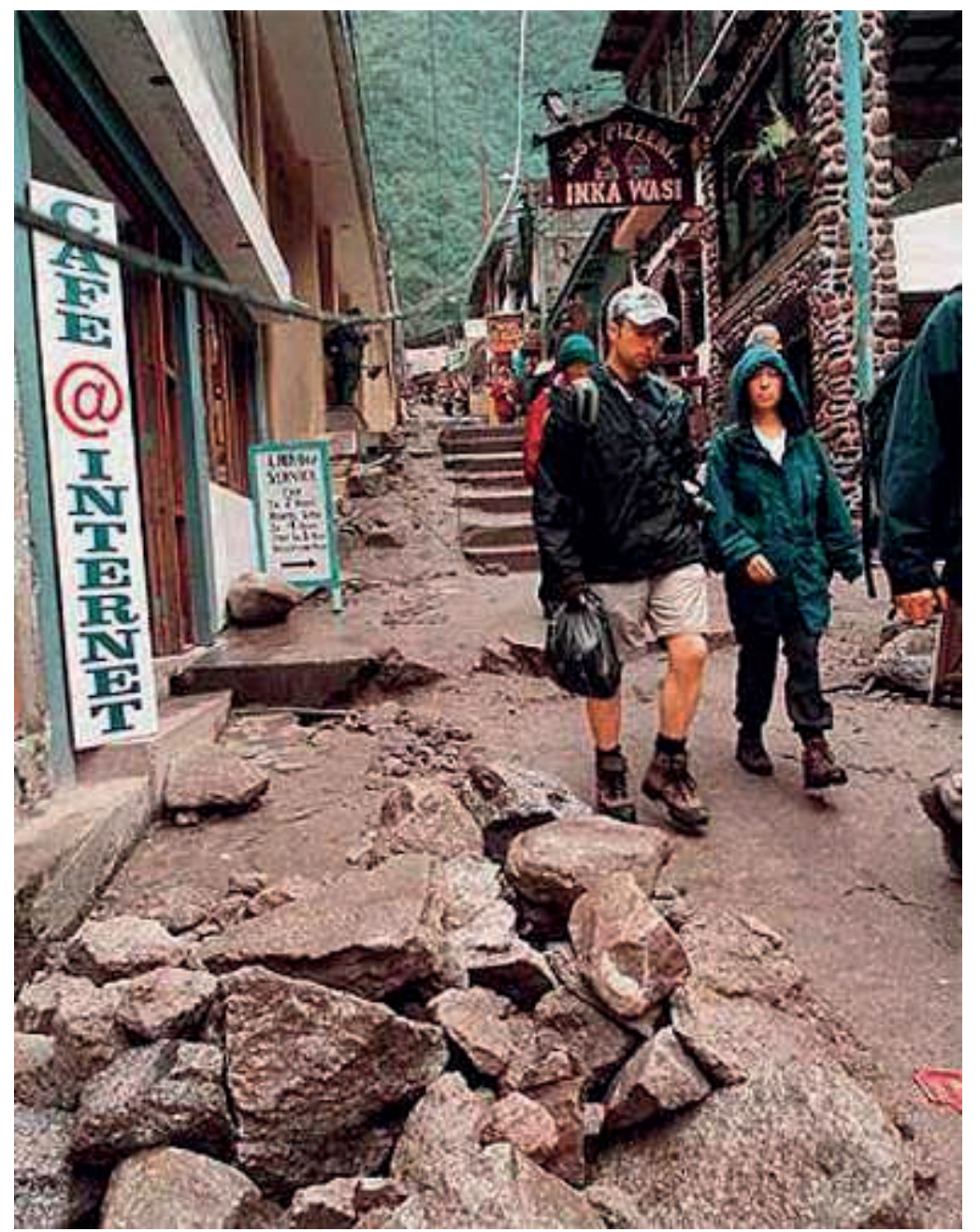

Al turista le aguardan estos recorridos al llegar a Aguas Calientes. Un pueblo que debería ser modelo da vergüenza.

No es nueva esta situación en Aguas Calientes. En "Aguas Hirvientes" (CARETAS 1721 de 16 de mayo del 2002), se mostraba el estado calamitoso del poblado y se destacaba un llamado del entonces embajador de Finlandia en el Perú, Mykko Pyhala, para que se establezca "una unidad de gestión bien institucionalizada y capaz de funcionar con gran autonomía, en beneficio del Santuario Histórico de Machu Picchu". El embajador estaba preocupado porque US\$ 3.5 millones de dólares de Finlandia, dedicados al distrito de Aguas Calientes, parte integrante del Santuario, se perdían irremediablemente. 
El Santuario genera ingresos por cerca de US\$ 1 millón de dólares mensuales, de los cuales 10\% queda en Aguas Calientes, sólo en entradas a la ruinas y por el recorrido del camino inca. El poblado mismo ha aumentado en forma significativa sus servicios turísticos los últimos años, llegando a contar con 500 camas y multitud de restaurantes. Alrededor de US\$ 4 millones por año generan las tres empresas de microbuses que suben a los turistas a las ruinas, una de las cuales es propiedad del municipio. Todo indica que recursos existen.

¿Qué es lo que pasa entonces?

El llamado del diplomático tuvo su efecto. El diario El Peruano de 11 de junio del 2002 consignaba que el presidente Toledo había dado instrucciones al vicepresidente Raúl Diez Canseco para que tomara cartas en el asunto. Según la publicación Diez Canseco había convocado de inmediato a una reunión con representantes de INC, Unesco, Unidad de Gestión de Machu Picchu, INRENA, Fondo Nacional de Areas Protegidas por el Estado (PROFONANPE), CTAR Cusco, PromPerú y Ministerio de Industrias. 

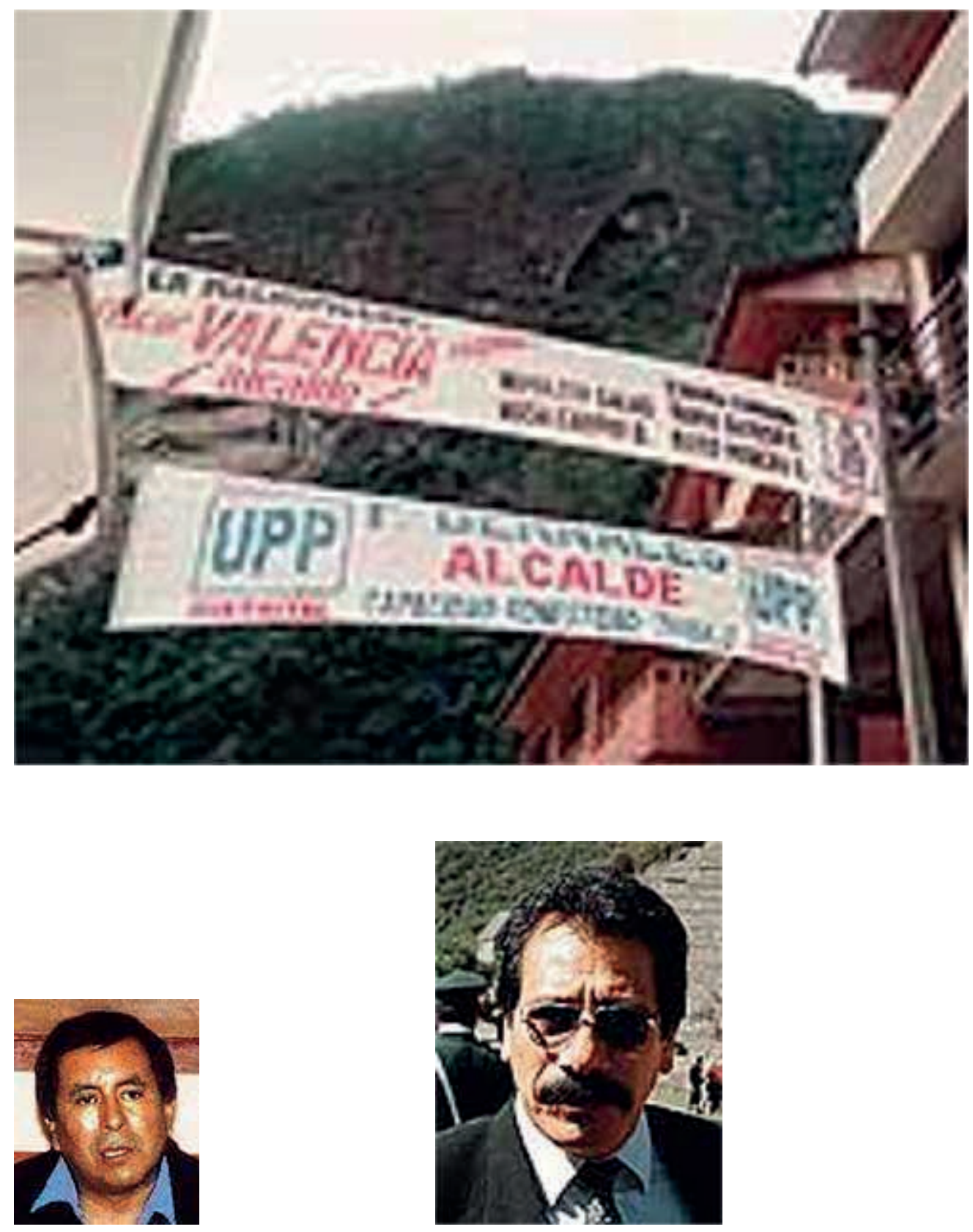

Pugna electoral. Oscar Valdivia (al lado) es apoyado por incompetente alcalde José Soto (extremo derecho).

A juzgar por la última visita realizada por CARETAS a la zona, o el Presidente no instruyó bien a su Vicepresidente o a éste se le hizo una ensalada con las siglas y las instituciones y prefirió no entrar a mayores (recuérdese a propósito que un camello 
es un caballo diseñado por una comisión). Porque la situación se ha agravado. Y peor aún, se vienen tiempos difíciles en vista de las próximas elecciones municipales. Se viene armando un zafarrancho de combate. Diez candidatos iniciaron la justa. Están que se dan de alma.

Quedan siete:

Visitación García (Movimiento Independiente Democracia Comunidad y Trabajo Machu Picchu); Florentino Zans (Organización Política Regional Inca Pachacútec); Angel Caipani (PAP); Guillermo Cusi (AP); Oscar Valencia (FIM); Porfirio Delgado (Movimiento por el Desarrollo de Machu Picchu y Comunidades); y Fermín Bernales (Agrupación Independiente Unión por el Perú Frente Amplio Machu Picchu).

Algunos al parecer incluyeron el plan de gobierno en la denominación de su movimiento; mas lo que llama realmente la atención es la proliferación de candidatos en una población de 1.000 habitantes (2.000 en la rural) y que súbitamente pasa de 900 electores, a 1.700. Un total de 800 mitimaes (costumbre incaica que consistía en trasladar pueblos enteros para su mejor dominio) traídos en partes proporcionales por los diferentes candidatos -con honrosas excepciones- entre los que destacaría el representante del Frente Independiente Moralizador con cerca de 200.

Qué duda cabe que Machu Picchu es la gallina de los huevos de oro. Pero parecería que muchos no se dan cuenta que le están torciendo el pescuezo.

\section{Recortes de Prensa II}

La irresponsabilidad e informalidad de autoridades y algunos malos empresarios vinculados al sector turismo parecieron darse de la mano ante una situación provocada por la naturaleza en Aguas Calientes, popular sector perteneciente al 
distrito de Machu Picchu Pueblo (Cusco), localidad muy frecuentada por turistas que van o regresan de las célebres ruinas. En abril del presente año (2004), sucedió lo que ya se había advertido, pero nadie hizo caso: dos "huaicos" -corrimientos de tierras - , provocados por las lluvias, causaron muerte y destrucción, obligando la evacuación de cientos de visitantes que de pronto se vieron atrapados por la furia de los elementos. Todo por culpa de la desidia y la ineptitud de funcionarios públicos que permitieron levantar, con documentos fraguados, hoteles y locales comerciales, además de casas, en un cauce fluvial. (14)

\subsection{Sucedió en Machu Picchu}

\subsubsection{Dos huaicos aíslan a 1500 turistas}

Redacción del diario OJO. Lima. (26)

Publicado el 11 de abril de 2004 (pp. 8-9)

Cuando todos dormían, la muerte llegó de madrugada al sector de Aguas Calientes, distrito de Machu Picchu, provincia de Urubamba (Cusco). Las intensas lluvias causaron dos huaicos en menos de una hora, y la gran masa de lodo y enormes piedras arrastró a diez personas que figuran como desaparecidas. Más tarde se halló uno de los cuerpos.

Además, quedaron varados unos 1500 turistas, nacionales y extranjeros, que habían llegado a la zona a pasar los feriados de Semana Santa.

Los huaicos se produjeron debido al embalse del río Alcamayo y el primero, con su carga de desgracia, se produjo a la 1:25 de la mañana, cuando los pobladores dormían plácidamente. Cayó en la entrada de Machu Picchu Pueblo cerca al restaurante Café Amazónico y afectó dos puentes y viviendas particulares aledañas. 
El siguiente huaico vendría a las 2:00 de la madrugada a la altura del kilómetro 101 de la línea férrea y cubrió de lodo 250 metros de largo de la misma, en el sector de Cedrobamba, entre las localidades de Pampacahua y Machu Picchu Pueblo.

Esta imprevista situación de emergencia y el que se necesitara evacuar a media docena de heridos y alrededor de 1500 turistas, hizo que se tendiera inmediatamente un puente aéreo con dos helicópteros.

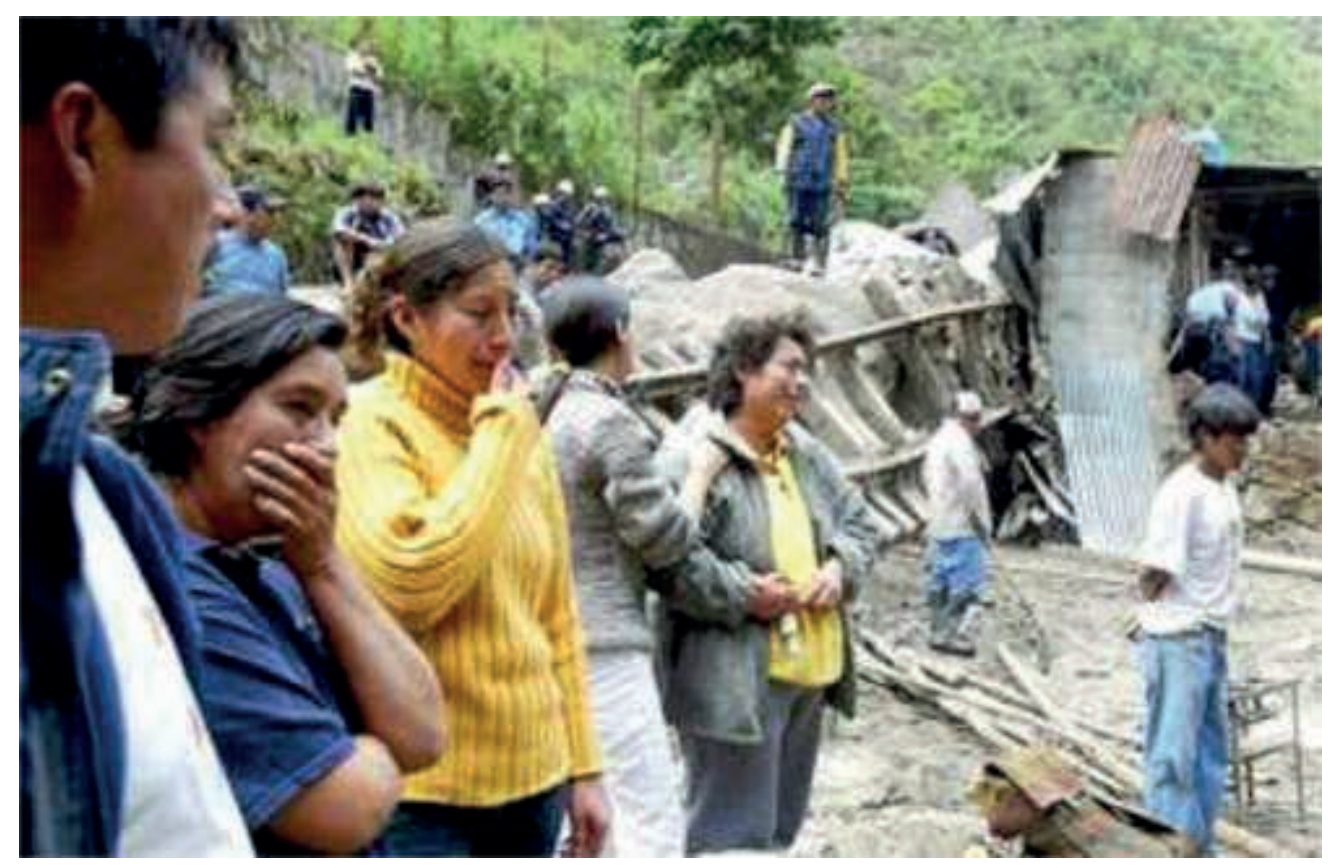

Figura 14. "Mujeres se lamentan al observar los daños causados por el alud en la ciudad de Aguas Calientes." Leyenda y foto publicada en el diario "Los Andes" de Mendoza, Argentina, el 12 de abril de 2004.

En un primer balance de esta desgracia, que empañó las celebraciones de Semana Santa en el Cusco, 60 familias resultaron damnificadas, seis viviendas destruidas, 35 viviendas afectadas, de las cuales 15 están en peligro de colapsar, dos puentes afectados y 250 metros de largo de la vía del ferrocarril que va a la ciudadela de Machu Picchu, cubiertos por un gran lodazal de casi un metro de espesor. 
Si en la madrugada los moradores del pueblo vivieron horas de terror, en la mañana fueron presas del desconsuelo, porque también perdieron tierras de cultivo y animales menores de corral.

"¡Fue horrible. El huaico vino con un gran ruido, pero la mayoría estaba durmiendo!", dijeron los desconsolados damnificados, quienes lamentaron la desaparición de vecinos de la comunidad.

Los heridos más graves eran hasta ese momento Angélica Puma Chipana y Daisy Valer, ambas con politraumatismo en el cuerpo. Horas después se halló el cada de Carlos Tapia Prudencio.

Los turistas extranjeros también fueron presas de una natural desazón y se preguntaban, ¿qué pasaría en las próximas horas?, mientras deambulaban por la zona en busca de un transporte al Cusco.

Inmediatamente conocida la tragedia, el presidente de la región, Carlos Cuaresma, el jefe de la Cuarta Región de Defensa Civil, Heraclio Boza, y hasta el mismo presidente Alejandro Toledo, quien se hallaba en la zona con el equipo de Travel Channel, dispusieron la ayuda inmediata a los damnificados y heridos, al tiempo de coordinar la evacuación de los más graves y de los turistas.

Por su parte, PerúRail, responsable del ferrocarril, movilizó a sus áreas operativas para realizar los trabajos de limpieza de la línea cubierta por las capas de lodo y piedras. La empresa suspendió el servicio de trenes hasta nuevo aviso, pero a más tardar se estima que para el lunes la línea estará operativa.

A media mañana, tres unidades vehiculares se trasladaron al lugar con alimentos y herramientas para socorrer a los damnificados y el jefe de la Cuarta Región de Indeci, 
Heraclio Boza, explicó que por la interrupción de las vías se hará transbordo en tres puntos.

Por su parte el presidente regional cusqueño, Carlos Cuaresma, refirió que se requiere con urgencia maquinaria pesada para encauzar el río Alcamayo, limpiar la línea férrea y retirar los bloques de piedra, de unas 200 a 300 toneladas, que vinieron con el huaico.

Indicó que el alcalde del Cusco, Carlos Valencia, se encuentra dirigiendo las labores de rescate con Defensa Civil.

El presidente regional indicó que ante la constante caída de huaicos en este sector, la unidad de gestión de Machu Picchu debe tomar acciones de prevención y no sólo de defensa del patrimonio.

\subsection{2. "Identifican a desaparecidos"}

Mientras el jefe de la Cuarta Región de Defensa Civil, Heraclio Boza, informó ayer que ningún turista figuraba como fallecido o desaparecido, el Ministerio de Salud (Minsa) identificó a las personas desaparecidas a consecuencia de los dos huaicos.

Se trata del ingeniero Roberto Rossel, ex gerente general de Enafer y dueño del hotel Amazonas, recinto que se levantaba entre los ríos Vilcanota y Alcamayo, Leonidas Yucra Luna, Alicia Gutiérrez Puma, Ronald Yucra Puma, Lucy Layme.

Asimismo, se encuentran como desaparecidos Eleazar Tapia, Romer Tapia, Carlos Daniel Tapia (3 meses), Juan Carlos Tapia y Carlos Tapia Prudencio, todos integrantes de una misma familia. 
Se informó que personal del Ministerio de Salud participa en las brigadas de búsqueda y rescate de los desaparecidos, mientras que los establecimientos de salud movilizaron varias ambulancias para socorrer a los afectados por los huaicos.

El centro de salud de Aguas Calientes atendió a cuatro heridos, dos de los cuales, Daysi Valer y José Luis Hurtado Cáceres, fueron dados de alta por no presentar mayores complicaciones con su estado de salud.

Permanecen internados, todavía en observación, Angélica Puma Chipana, con traumatismo encéfalo-craneano moderado, y Haydée García Ramos, con posible fractura de la rodilla. Ambas fueron trasladadas al Hospital Regional del Cusco.

Por su parte el presidente del gobierno regional del Cusco, Carlos Cuaresma, calificó la situación en la zona como dramática, y pidió ayuda para enfrentar la emergencia.

Cuaresma aseguró que también se necesitan carpas, alimentos, medicina y abrigo para apoyar a los damnificados en estos momentos difíciles.

\subsubsection{Cifras}

1911 es el año en que el norteamericano Hiram Bingham descubrió la imponente ciudadela de Machu Picchu, que nunca había podido ser hallada por los españoles y que es considerada Patrimonio de la Humanidad.

2350 metros sobre el nivel del mar es la ubicación de la ciudadela inca, que además tiene una temperatura media anual de $13^{\circ} \mathrm{C}$, propio de la ceja de selva donde fue construida hace varios cientos de años. 
112 kilómetros de distancia por vía férrea separan a la ciudad del Cusco de la estación de Puente Ruinas o Machu Picchu.

3 formas hay de llegar a la ciudadela de Machu Picchu. Viajando tres horas en tren. Recorriendo 112 kilómetros del Camino Inca durante cuatro días, para lo cual se requiere un adecuado estado físico, o volando en helicóptero hasta el pueblo de Aguas Calientes. Con esta última alternativa se llega en 55 minutos hasta la ciudadela inca.

78 escalones, todos finamente labrados, tienen que trepar los turistas que desean llegar hasta el Intiwatana o reloj solar diseñado por los incas y que es una de las maravillas de Machu Picchu.

800 metros al este de Aguas Calientes se encuentran las fuentes de aguas termales sulfurosas que emergen del subsuelo rocoso. La temperatura promedio de estas aguas es de $38^{\circ} \mathrm{C}$ a $46^{\circ} \mathrm{C}$. La zona está acondicionada para recibir a los turistas interesados en este tipo de lugares.

2500 turistas diarios recibe Aguas Calientes. Este es un pequeño pueblo con sólo tres mil habitantes y 150 mil soles anuales de presupuesto. Los 2500 turistas diarios llegan durante la época alta de turismo, vale decir julio, agosto y setiembre.

Volver al principio del recorte Volver al principio de procedencia de recortes de prensa II $\quad$ Volver al principio del artículo Volver al principio

\section{Recortes de Prensa III}

\section{1. Mafia opera en el aeropuerto}

Artículo de Jesús Palomino. Diario OJO. Lima (26) 
Publicado el 2 de febrero de 2004 pp. No hay datos.

Detectives de inteligencia iniciaron las pesquisas para desbaratar a una banda de asaltantes y secuestradores que vienen operando desde el interior del aeropuerto internacional Jorge Chávez, quienes haciéndose pasar como taxistas secuestran al paso a viajeros peruanos o extranjeros a los que golpean y roban todas sus pertenencias. Los capturados son Martín Cáceda Guaylupo y José Casanova Vargas, quienes secuestraron a Ruth Isabel Aliaga Abanto. La mujer había llegado de Argentina y se disponía a viajar a Chiclayo, cuando fue sorprendida por los delincuentes. Con engaños fue llevada al auto de placa SOA-470 donde la subieron a viva fuerza y fue un testigo quien dio aviso a la policía, que inició un operativo llegando a ubicar el auto en una zona oscura del asentamiento humano Bocanegra, donde se descubrió a los sujetos golpeando a su víctima para que llame a su familia y les pida dinero como rescate. Los policías pusieron a los detenidos a disposición de la unidad antisecuestros donde se prosiguió con las pesquisas, pero se supo que ambos sujetos pertenecen a una banda organizada especializada en secuestrar personas del interior del aeropuerto, en algunas oportunidades como taxistas y en otras como intérpretes o guías de turistas.

\subsubsection{Mafia bajo la lupa}

Tras conocer este hecho el comando policial ordenó a un equipo de inteligencia realizar un intenso trabajo de vigilancia y ubicación de los otros miembros de esta banda de secuestradores, que viene operando desde hace un mes en las instalaciones del aeropuerto internacional Jorge Chávez. Tras las primeras pesquisas realizadas ayer se pudo saber que también existen empleados del terminal aéreo que se encuentran involucrados y que algunos de los delincuentes además "marcan" (vigilan) a las personas que realizan retiros de los cajeros. Asimismo, estos asaltantes mantienen a sus víctimas secuestradas por inmediaciones del aeropuerto y les quitan 
sus tarjetas de crédito para hacer retiros con ellas desde cajeros ubicados en el aeropuerto, para luego abandonarlas en la periferia de Lima. 